\title{
8. GEOTECHNICAL PROPERTIES OF GLACIGENIC SHELF SEDIMENTS FROM PRYDZ BAY, EAST ANTARCTICA ${ }^{1}$
}

\author{
Anders Solheim, ${ }^{2}$ Carl Fredrik Forsberg, ${ }^{3}$ and Alan Pittenger ${ }^{4}$
}

\begin{abstract}
This paper presents a geotechnical characterization of the glacigenic sediments in Prydz Bay, East Antarctica, based on the shipboard physical properties data obtained during Leg 119, combined with results of land-based analyses of 24 whole-round core samples. Main emphasis is placed on the land-based studies, which included oedometer consolidation tests, triaxial and simple shear tests for undrained shear strength, permeability tests in oedometer and triaxial cell, Atterberg limits, and grain-size analyses. The bulk of the tested sediments comprise overconsolidated diamictites of a relatively uniform lithology. The overconsolidation results from a combination of glacial loading and sediment overburden subsequently removed by extensive glacial erosion of the shelf. This leads to downhole profiles of physical properties that have been observed not to change as a function of the thickness of present overburden. A number of fluctuations in the parameters shows a relatively systematic trend and most likely results from changes in the proximity to the ice sheet grounding line in response to variations in the glacial regime. Very low permeabilities mainly result from high preconsolidation stresses $\left(P_{c}{ }^{\prime}\right) . P_{c}{ }^{\prime}$ values up to $10,000 \mathrm{kPa}$ were estimated from the oedometer tests, and empirical estimates based on undrained shear strengths (up to $2500 \mathrm{kPa}$ ) indicate that the oedometer results are conservative. The diamictites generally classify as inactive, of low to medium plasticity, and they consolidate with little deformation, even when subjected to great stresses.

This is the first report of geotechnical data from deep boreholes on the Antarctic continental shelf, but material of similar character can also be expected in other areas around the Antarctic.
\end{abstract}

\section{INTRODUCTION}

Five sites (739-743) were drilled across the continental shelf and upper slope during Ocean Drilling Program (ODP) Leg 119 (Fig. 1A). The cored sequence consists of sediments ranging from preglacial terrestrial sandstones (possibly of Early Cretaceous age) to Holocene diamictons and diatomaceous sediments (Barron, Larsen, et al., 1989). The main part of the recovered material, however, consisted of glacigenic sediments, with massive to weakly stratified diamictites and diamictons as the predominant lithology (Hambrey et al., this volume). This is typified by the two outermost shelf sites, Sites 739 and 742 , and by Site 743 on the upper continental slope. Sites 739 and 742 provide evidence of the influence of major ice sheets at least since early Oligocene time, and possibly earlier. The onset of glaciation was, however, not recorded.

Reports on geotechnical properties of Antarctic sediments are sparse. Most work has been on surficial sediments obtained by gravity and piston corers (Anderson et al., 1977, 1980, 1984; Kurtz et al., 1979; Edwards et al., 1987). The only geotechnical studies reported on deeper, drilled sediments have been from Deep Sea Drilling Project (DSDP) and ODP sites, from Legs 28 and 113, respectively, of which only DSDP Leg 28 drilled on the continental shelf proper. The reported geotechnical studies from these sediments have included only shipboard analyses.

Shipboard-measured physical properties data from Leg 119 indicated a generally high but varying degree of overconsolidation in the recovered diamictites (Shipboard Scientific Party, $1989 \mathrm{~b}, 1989 \mathrm{c})$. Subsequent laboratory consolidation tests have

' Barron, J., Larsen, B., et al., 1991. Proc. ODP, Sci. Results, 119: College Station, TX (Ocean Drilling Program).

${ }^{2}$ Norwegian Polar Research Institute, P.O. Box 158, N-1330 Oslo Lufthavn, Norway.

${ }^{3}$ Norwegian Geotechnical Institute, P.O. Box 40, Tasen, N-0801 Oslo 8, Norway.

${ }^{4}$ Department of Oceanography, Texas A\&M University, College Station, TX 77845 , U.S.A. confirmed this picture and also thrown some light on the consolidation history of the shelf sediments (Solheim et al., chapter 9 , this volume). In this paper, we present a geotechnical characterization of these Antarctic unsorted glacigenic sediments based on both shipboard results and the results of land-based studies. The presentation given in this paper also provides background information for the paper by Solheim et al. (chapter 9, this volume), which discusses the results of consolidation tests with respect to the stress history of the sediments. In particular, the characteristics of the high-strength diamictites of Sites 739 and 742 will be discussed.

\section{MATERIALS AND METHODS}

The overall structure of the Prydz Bay continental shelf, as seen seismically (Stagg, 1985; Cooper et al., this volume), consists of a sequence of seaward weakly dipping strata on the inner shelf, followed laterally by more steeply dipping strata on the outer shelf (Fig. 1B). The latter forms a thick prograding sequence. All dipping strata are cut by a regional angular unconformity and overlain by up to $200 \mathrm{~m}$ of flat-lying strata (Cooper et al., this volume) (Fig. 1B).

The drilled part of the sequence consists mainly of clastic sediments, with the exception of some diatomaceous deposits within the uppermost few meters below seafloor (mbsf), in particular at Site 740 (Barron, Larsen, et al., 1989). The recovered sediments at Site 743 , on the upper continental slope consist entirely of diamicton (Fig. 2). The upper parts of the four shelf sites also consist of diamicton, but this is underlain by stiff diamictites at these sites. At Sites 739 and 742, various facies of upper Paleogene through Neogene diamictites (with the exception of a few thin diatom-rich siltstone beds) form the entire cored sequence below the diamictons (Fig. 2). Carbonate cementation was found in the lower parts of Holes $739 \mathrm{C}$ and $742 \mathrm{~A}$. At Sites 740 and 741 , the diamictites are underlain by presumably pre-Tertiary sandstones and siltstones (Truswell, this volume) (Fig. 1B).

The diamictons and diamictites (Fig. 3) are interpreted as representing various types of glacigenic deposits, ranging from 

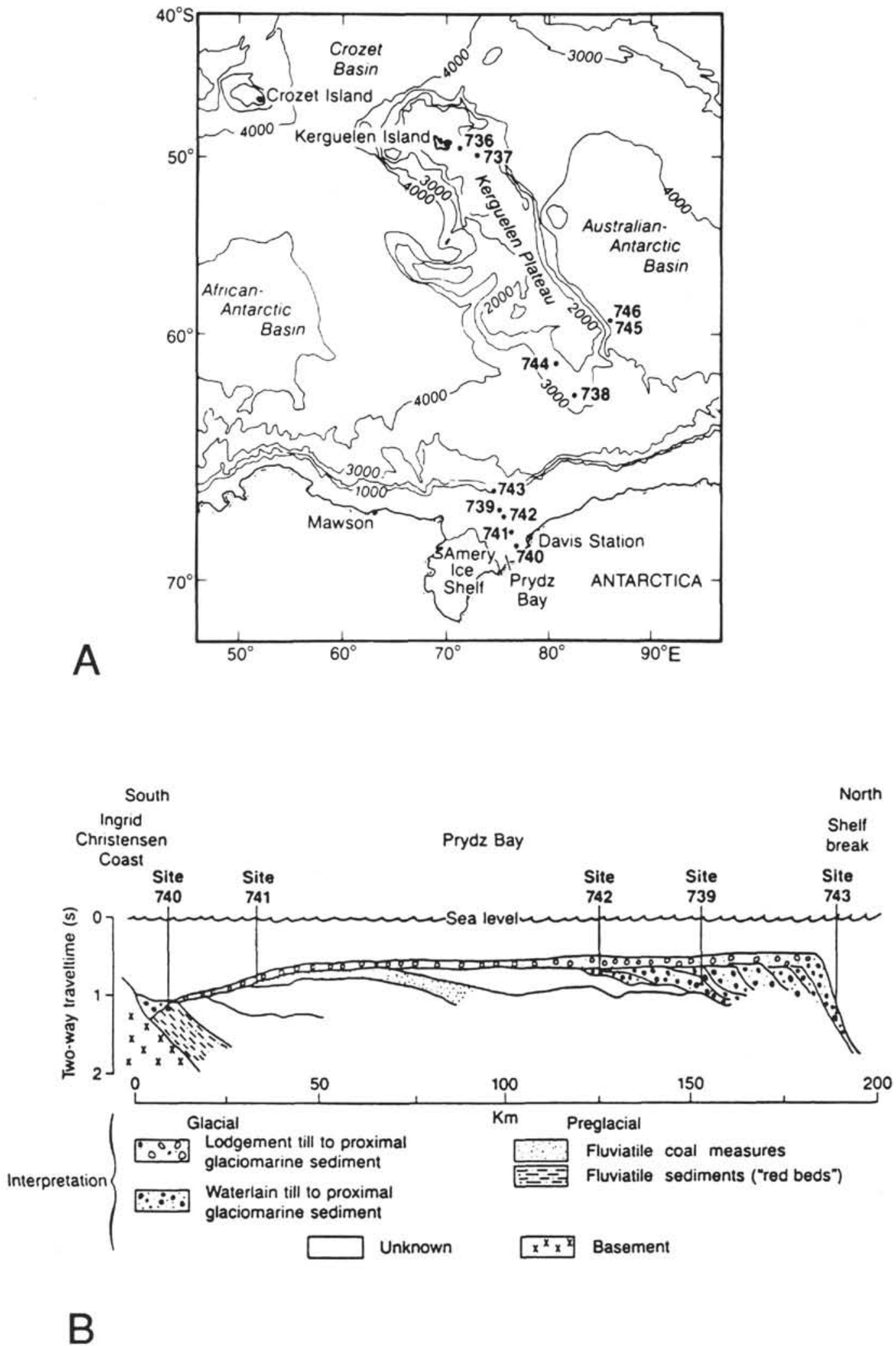

Figure 1. A. Map showing the sites drilled during Leg 119. B. Schematic cross section of the Prydz Bay continental shelf, based on seismic stratigraphy and borehole data from Leg 119 (from Hambrey et al., 1989). 


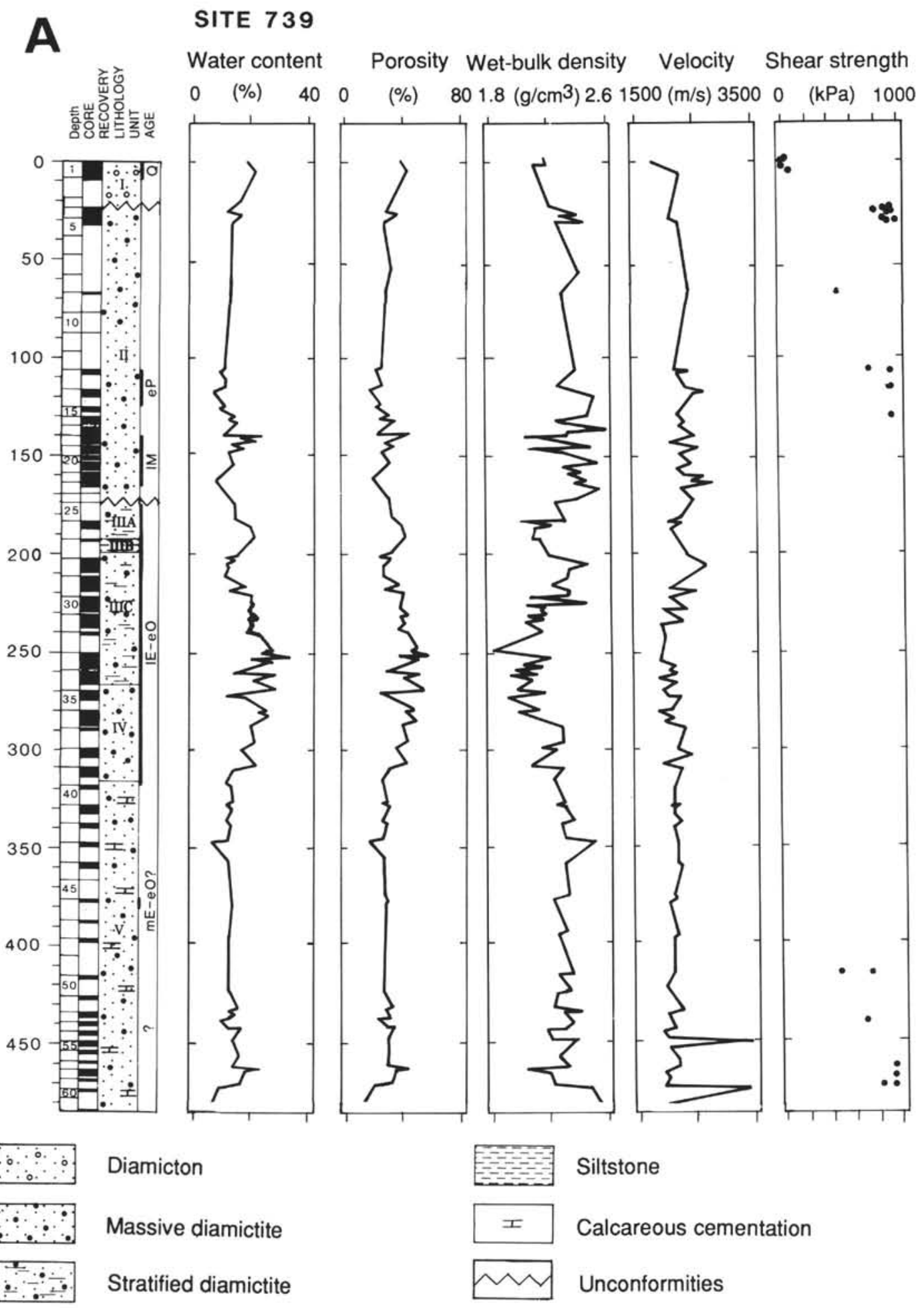

Figure 2. Results of shipboard measurements of water content (percent of wet weight), porosity, wet-bulk density, $P$ wave velocity, and undrained shear strength at Sites 739 (A), 742 (B) and 743 (C). See Appendix for exact values of the different properties. The lithostratigraphic units are taken from Hambrey et al. (this volume) and the ages are from shipboard biostratigraphy (Barron, Larsen, et al., 1989).

lodgement till through waterlain till to more distal glacial marine deposits (Hambrey et al., this volume). The older, presumably preglacial sediments of Sites 740 and 741 most likely represent continental alluvial plain and fluvial sedimentation (Turner, this volume; Turner and Padley, this volume).

\section{Sampling and Sample Disturbance}

With the exception of those at Site 743 , the whole-round core samples used in this study were obtained by rotary coring. Because of the potential for severe sample disturbance, this 

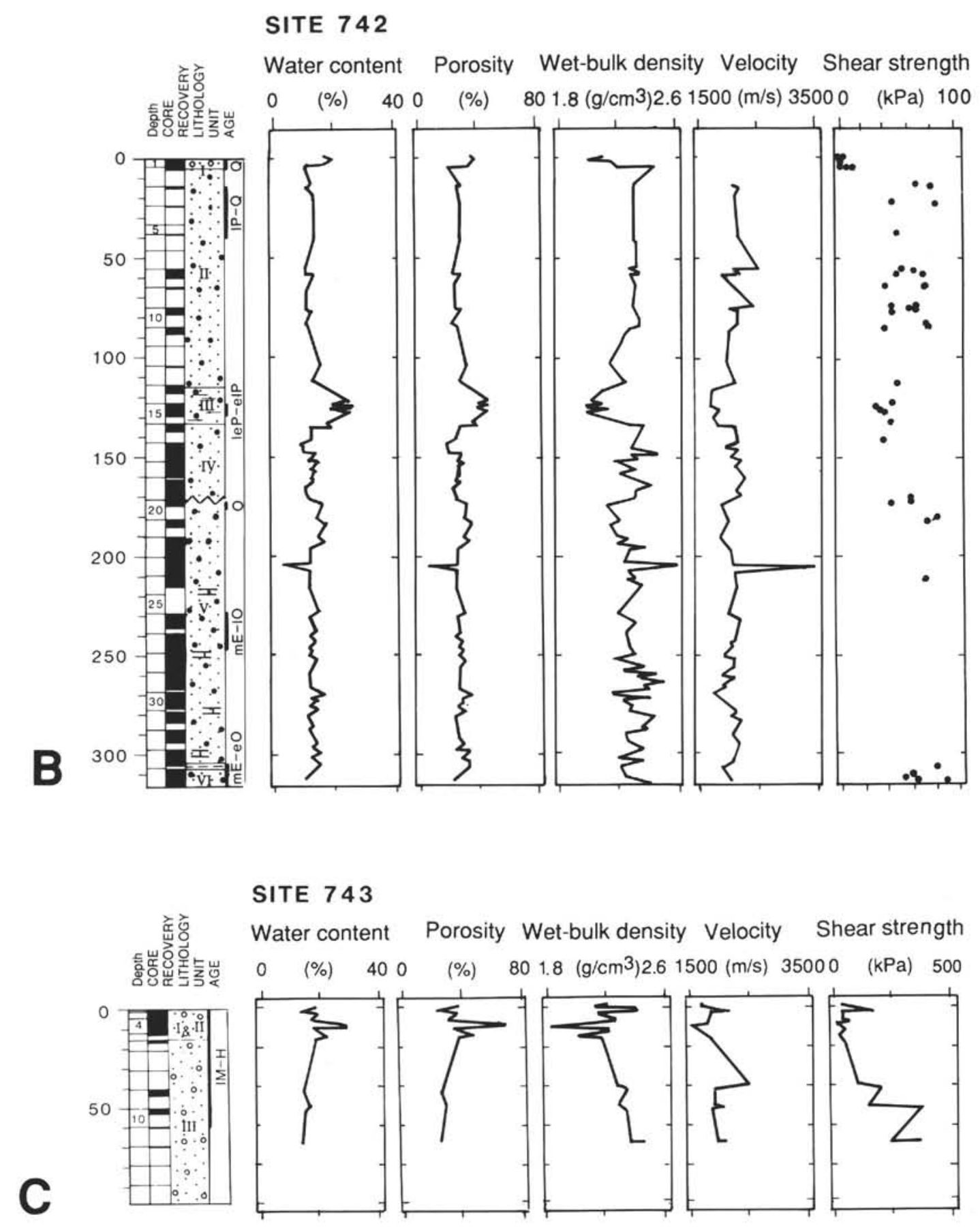

BIOSTRATIGRAPHIC AGE
H Holocene
E Eocene
Q Quaternary
I late
P Pliocene
m middle
M Miocene
e early
- Oligocene

Figure 2 (continued). 


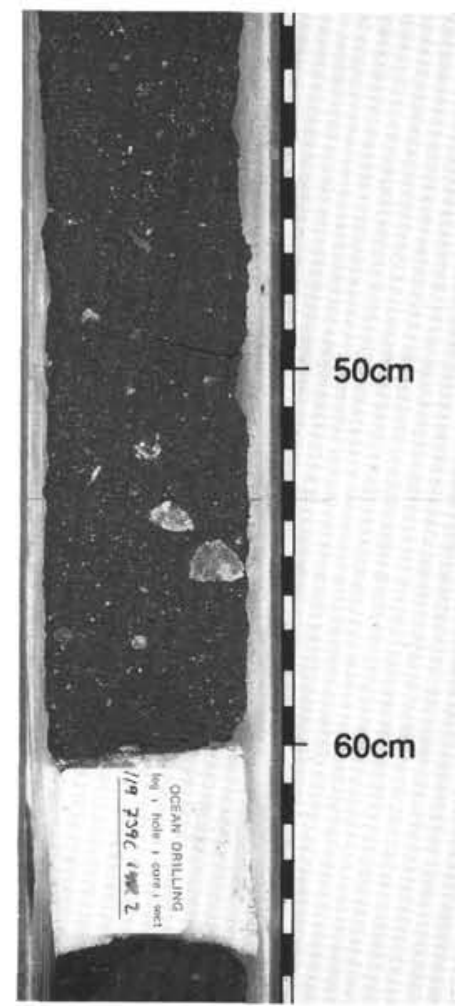

Figure 3. Photograph of diamictite in Section 119-739C-14R-2, 41-66 $\mathrm{cm}$, typical for the glacigenic sediments of Prydz Bay. The white, labeled part is a styrofoam-filled void after removal of a geotechnical whole-round core sample.

technique is not generally used for obtaining geotechnical samples. However, most of the observed disturbance of the diamictites was in the form of fracturing and shearing to various degrees, which is also apparent from the core photographs and descriptions (Barron, Larsen, et al., 1989). In choosing the whole-round core samples, fractured or sheared zones were carefully avoided, and during the mounting for the triaxial and oedometer tests, the outer 3 to $5 \mathrm{~mm}$ of the samples were removed. Possible sample disturbance was also checked against empirical data from offshore Norway (Lacasse, 1988). These data relate sample disturbance to the range of strain likely at loads equal to the present overburden $\left(P_{o}^{\prime}\right)$. Based on this and the generally careful sample treatment, significant disturbance of the stiff diamictites is considered unlikely. Techniques and routines used for preparing, packing, and storage of the samples are further described by Solheim et al. (chapter 9, this volume).

\section{Analyses}

Shipboard measurements of sediment physical properties included water content (percent of wet weight), porosity, wet-bulk density, dry-bulk density, grain density, undrained shear strength, compressional- $(P)$-wave velocity, and thermal conductivity. Samples used for shipboard measurements were in the order of $5 \mathrm{~cm}^{3}$ of volume, and care was undertaken to obtain as representative samples as possible. Because of the potentially great effect on these small samples, however, larger clasts were avoided. The methods used and the measurements and results at each site are thoroughly discussed in the Leg 119 Initial Reports volume (Barron, Larsen, et al., 1989).

Shore-based geotechnical analyses have been carried out on 24 whole-round core samples (Table 1). There are samples from all the sites and different sediment types, but the main emphasis is on the glacial sediments of Sites 739 and 742 . Analyses performed on the samples were oedometer consolidation tests, constant head permeability tests in oedometer and triaxial cell, unconfined compression, simple shear and triaxial tests for undrained shear strength, Atterberg limits and grain-size analyses. At Sites 739, 742, and 743, grain-size analyses were also carried out on approximately every other of the shipboard samples analyzed for water content, porosity, and bulk density (see Appendix).

All whole-round core samples were X-ray photographed, and the X-radiographs were used during mounting of the test specimen to avoid larger clasts. These would affect the tests, which originally were designed for homogeneous clays. The methods used for oedometer consolidation tests are described by Solheim et al. (chapter 9, this volume). The two unconfined compression tests were unsuccessful because of fracturing of the samples during testing, and these tests will therefore not be further discussed. One simple shear test and four triaxial tests were performed using procedures described in detail by Berre (1981) and Andresen et al. (1979). In the simple shear test, the sample is trimmed down to $50 \mathrm{~mm}$ in diameter and $16 \mathrm{~mm}$ in height, confined by a steel-reinforced rubber membrane and mounted between two filter stones. The sample is then vertically consolidated to the preconsolidation pressure $\left(P_{c}{ }^{\prime}\right)$, which was found from oedometer tests (Solheim et al., chapter 9, this volume), and subsequently unloaded to $P_{o}{ }^{\prime}$. Shearing is then accomplished by moving the upper filter stone horizontally at a constant strain rate while keeping the sample height constant.

The four samples for triaxial tests were trimmed down to a diameter of $54 \mathrm{~mm}$. Heights varied between 69.8 and $112 \mathrm{~mm}$. The samples were mounted in a rubber membrane and with polished steel plates at the ends to reduce end friction. Before shearing, the samples were consolidated to the same effective stresses as they carried in the field. To estimate the effective horizontal stress, the earth pressure coefficient at rest $\left(K_{o}{ }^{\prime}\right)$ was estimated from values of over-consolidation ratio (OCR, from consolidation tests) and plasticity index $\left(I_{p}\right)$ after relationships published by Brooker and Ireland (1965). The samples were then sheared by static, undrained compression (CAUa test), by keeping the horizontal stress constant and increasing the vertical stress. The tests were run up to approximately $20 \%$ strain at a strain rate of $1 \%-2 \%$ per hour. The coefficient of permeability $(k)$ was measured by the constant head permeability test (Bjerrum and Huder, 1957; Lambe and Whitman, 1979) for two of the samples tested in the triaxial cell.

Grain-size analyses were carried out on all whole-round core samples by sieving for fractions $>63 \mu \mathrm{m}$ and Sedigraph $5000 \mathrm{D}$ analyses for the silt and clay fractions. The analyzed samples varied in dry weight from $7.81 \mathrm{~g}$ to $28.24 \mathrm{~g}$, averaging $15-20 \mathrm{~g}$. The shipboard samples (Barron, Larsen, et al., 1989) were analyzed with the same techniques, but without differentiating the sand fractions for these samples. The shipboard samples were mostly between 5 and $10 \mathrm{~g}$ of sediment although both larger and smaller samples did occur.

All whole-round core samples were analyzed for Atterberg limits. The samples were wet sieved through a $75-\mu \mathrm{m}$ sieve and the plastic limit determined by measuring the water content of the sediment when it ceases to behave plastically when rolled by hand into cylinders $3.2 \mathrm{~mm}$ in diameter (Norwegian Standard, 1982b). The liquid limit was determined using a fall cone penetrometer in a remolded sample (Norwegian Standard, 1982a).

\section{RESULTS}

\section{Shipboard Analyses (Appendix)}

At Site 743 , on the upper continental slope, the physical properties show values typical of normally consolidated diamic- 
Table 1. Whole-round core samples from the Prydz Bay sites, with performed tests and lithology indicated.

\begin{tabular}{|c|c|c|c|c|}
\hline $\begin{array}{c}\text { Sample } \\
\text { (interval in } \mathrm{cm} \text { ) }\end{array}$ & $\begin{array}{l}\text { Depth } \\
\text { (mbsf) }\end{array}$ & $\begin{array}{l}\text { Length } \\
\text { (cm) }\end{array}$ & Lithology & Test $^{\mathrm{a}}$ \\
\hline \multicolumn{5}{|l|}{$119-739 \mathrm{C}-$} \\
\hline $4 R-3,0-15$ & 27.10 & 15 & Massive diamictite & Triax \\
\hline SR-1, 94-99 & 29.64 & 5 & Massive diamictite & Cons \\
\hline $13 \mathrm{R}-1,140-150$ & 107.30 & 10 & Massive diamictite & Cons, DSS \\
\hline $14 R-2,60-65$ & 117.60 & 5 & Massive diamictite & Cons \\
\hline $15 \mathrm{R}-1,119-124$ & 126.39 & 5 & Massive diamictite & Cons \\
\hline $16 \mathrm{R}-1,135-150$ & 131.65 & 15 & Massive diamictite & Triax \\
\hline $17 \mathrm{R}-2,145-150$ & 137.95 & 5 & Massive diamictite & Cons \\
\hline $19 \mathrm{R}-1,135-150$ & 146.05 & 15 & Massive diamictite & Triax, Perm \\
\hline $21 \mathrm{R}-1,18-23$ & 154.48 & 5 & Massive diamictite & Cons \\
\hline $23 \mathrm{R}-2,31-36$ & 165.81 & 5 & Massive diamictite & UCT \\
\hline $26 \mathrm{R}-2,140-145$ & 186.10 & 5 & Stratified diamictite & Cons \\
\hline $30 \mathrm{R}-5,19-24$ & 227.99 & 5 & Stratified diamictite & Cons \\
\hline \multicolumn{5}{|l|}{$119-740 \mathrm{~A}-$} \\
\hline $3 R-3,145-150$ & 18.15 & 5 & Massive diamicton & Cons \\
\hline \multicolumn{5}{|l|}{$119-741 \mathrm{~A}-$} \\
\hline 5R-2, 91-96 & 35.91 & 5 & Sand/siltstone & Cons \\
\hline $6 \mathrm{R}-1,78-83$ & 43.98 & 5 & Sand/siltstone & Cons \\
\hline $10 \mathrm{R}-2,63-68$ & 84.03 & 5 & Sand/siltstone & Cons \\
\hline \multicolumn{5}{|l|}{$119-742 \mathrm{~A}=$} \\
\hline $8 \mathrm{R}-2,86-91$ & 57.86 & 5 & Massive diamictite & Cons \\
\hline $14 \mathrm{R}-1,21-26$ & 113.51 & 5 & Massive diamictite & Cons \\
\hline $17 \mathrm{R}-1,49-54$ & 142.79 & 5 & Diffusely layered diamictite & Cons \\
\hline $19 \mathrm{R}-5,133-138$ & 169.03 & 5 & Diffusely layered diamictite & UCT \\
\hline $21 \mathrm{R}-2,0-5$ & 182.50 & 5 & Massive diamictite & Cons \\
\hline $23 \mathrm{R}-3,102-107$ & 204.32 & 5 & Massive diamictite & Cons \\
\hline \multicolumn{5}{|l|}{$119-743 \mathrm{~A}$} \\
\hline $4 \mathrm{H}-3,135-150$ & 8.95 & 15 & Massive diamicton & Triax \\
\hline $9 \mathrm{X}-1,145-150$ & 41.65 & 5 & Massive diamicton & Cons \\
\hline
\end{tabular}

Note: All samples are analyzed for grain-size distribution and Atterberg limits.

a Laboratory test performed: Triax = triaxial test for measurement of undrained shear strength; Cons = consolidation test in oedometer; DSS = direct shear test for measurement of undrained shear strength; Perm = permeability measurement in triaxial cell; UCT $=$ unconfined compression test for measurement of undrained shear strength.

tons (Bennett and Nelsen, 1983; Lunne et al., 1983; Eide and Andersen, 1984; Amundsen et al., 1987; Solheim et al., 1988; Solheim, in press; Lien et al., 1989) and a gradual downhole effect of increased overburden (Fig. 2C). The water content (percent of wet weight) drops from values slightly below $20 \%$ in the top to $12 \%-13 \%$ at 69 mbsf. Porosity drops from $36 \%-38 \%$ at the top to $27 \%$ at $69 \mathrm{mbsf}$. Wet-bulk density increases downhole from 2.2 to $2.35 \mathrm{~g} / \mathrm{cm}^{3}$, compressional wave ( $P$-wave) velocity increases from approximately 1700 to $2000 \mathrm{~m} / \mathrm{s}$, and undrained shear strength increases from values about $30 \mathrm{kPa}$ to values about $200-300 \mathrm{kPa}$. The only deviation from this trend is a layer defined in Sections 119-743A-4H-4 and 119-743A-4H-5. Here, significantly raised values of water content $(32 \%)$ and porosity $(56 \%)$ and lower values of bulk density $\left(1.85 \mathrm{~g} / \mathrm{cm}^{3}\right)$ and velocity $(1600 \mathrm{~m} / \mathrm{s})$ are assumed to be effects of lithologic differences (Shipboard Scientific Party, 1989d). Undrained shear strength, on the other hand, showed no significant variations in this interval (Fig. 2C).

In the two sites with the thickest glacigenic sequences, Sites 739 and 742 , a thin upper cover of soft diamictons and diatomaceous deposits with physical properties similar to those in the upper part of Hole 743A (Fig. 2 and Appendix) is underlain by diamictites. Physical properties of the cored diamictites show them to be highly compacted, even at shallow burial depths, and with no further downhole trends apparent that can be as- cribed to the effects of increased overburden. Hence, the diamictites of Sites 739 and 742 clearly bear evidence of a past consolidation history. Values of porosity and water content are generally low, in the order of $30 \%$ and $15 \%$, respectively, as an average, while bulk density and velocity are correspondingly high, $2.26 \mathrm{~g} / \mathrm{cm}^{3}$ and $2200 \mathrm{~m} / \mathrm{s}$, respectively, on average. Undrained shear strength was generally too high to be measured by the shipboard devices (i.e., greater than $900 \mathrm{kPa}$; Shipboard Scientific Party, 1989a). Considerable variation is, however, superimposed on the average values (Fig. 2 and Appendix). At Site 739 , this is particularly significant in the interval between approximately 170 and 310 mbsf (Fig. 2), where the values fluctuate between distinct maxima and minima. Water content values within this interval vary between $14 \%$ and $32 \%$, porosity between $25 \%$ and $57 \%$, wet-bulk density between 1.9 and $2.5 \mathrm{~g} /$ $\mathrm{cm}^{3}$, and $P$-wave velocity between 1800 and $2700 \mathrm{~m} / \mathrm{s}$. At Site 742 , variations of similar appearance are found between approximately 114 and 195 mbsf (Fig. 2). At this site, water content varies between $8 \%$ and $27 \%$, porosity between $18 \%$ and $47 \%$, wet-bulk density between 2.0 and $2.5 \mathrm{~g} / \mathrm{cm}^{3}$, and $P$-wave velocity between 1700 and $2300 \mathrm{~m} / \mathrm{s}$.

Possible interpretations of the small-scale fluctuations, however, as stated in Barron, Larsen, et al. (1989), are that they could be due to variations in degree of compaction, lithologic effects, or a combination of the two. Therefore, the shore-based 
program included both consolidation studies and grain-size distribution analyses of the samples analyzed aboard ship.

\section{Shore-based Analyses}

\section{Grain-size Distributions}

Downhole grain-size distributions for Sites 739, 742, and 743 are shown in Figure 4. Of the whole-round samples from the remaining two sites, 740 and 741 , only one and three analyses, respectively, were carried out. All the downhole grain-size distribution profiles show clay and sand to be the predominant fractions, with slightly less silt and minor gravel. The clay content varies between $15 \%$ and $68 \%$, silt between $4 \%$ and $79 \%$, sand between $0.5 \%$ and $69 \%$, and gravel between $0 \%$ and $18 \%$. Because of the relatively small volumes of the samples analyzed, particularly the gravel fraction may be statistically invalid.

Although grain-size analysis for Sites 739 and 742 also were carried out by Hambrey et al. (this volume), it was necessary to have the various analyses carried out on the same samples in order to be able to relate grain-size characteristics to other physical properties. The results of the present study compare well with those of Hambrey et al. (this volume). The main trends are similar, but the clay content of this study is slightly greater than that measured by Hambrey et al. (this volume). Most likely, this results from the different methods used (pipette vs. Sedigraph) for the fine fractions (Løken et al., 1986). Furthermore, the gravel content measured by Hambrey et al. (this volume) was measured visually on cut core halves, and is probably more representative than in the present study.

No significant site-to-site trends seem to be present, with the possible exception that the silt content appears higher and the clay content lower at Site 739 than at Sites 742 and 743 (Fig. 4). A greater number of samples is needed, however, to make the difference statistically significant. This is most evident looking at lithostratigraphic Unit II at Site 739 and Units II, III, and IV of Site 742, which tentatively are intercorrelated (Barron, Larsen, et al., 1989). Downhole trends essentially follow the lithostratigraphic divisions given by Barron, Larsen, et al. (1989) and Hambrey et al. (this volume). The stratified units (Fig. 2) generally have a higher content of clay and silt than the massive diamictites.

More important to this study, however, is the close association between the grain-size distribution and some of the physical properties (Fig. 5). Because of the unsorted character of the sediment and the small sample volumes involved in the measurements, there is a wide scatter in individual data points. However, the main downcore trends in mud content and porosity (Fig. 5A), water content, and bulk density at Sites 739,742 , and 743 show a good correspondence. The mud content correlates with the water content, porosity, wet-bulk density, and $P$ wave velocity with the correlation coefficients $0.70,0.66$, and -0.71 , and -0.48 , respectively (Fig. 5B). This is particularly evident in the intermediate parts of the drilled sequence at Sites 739 and 742 , where high porosity values clearly correspond with

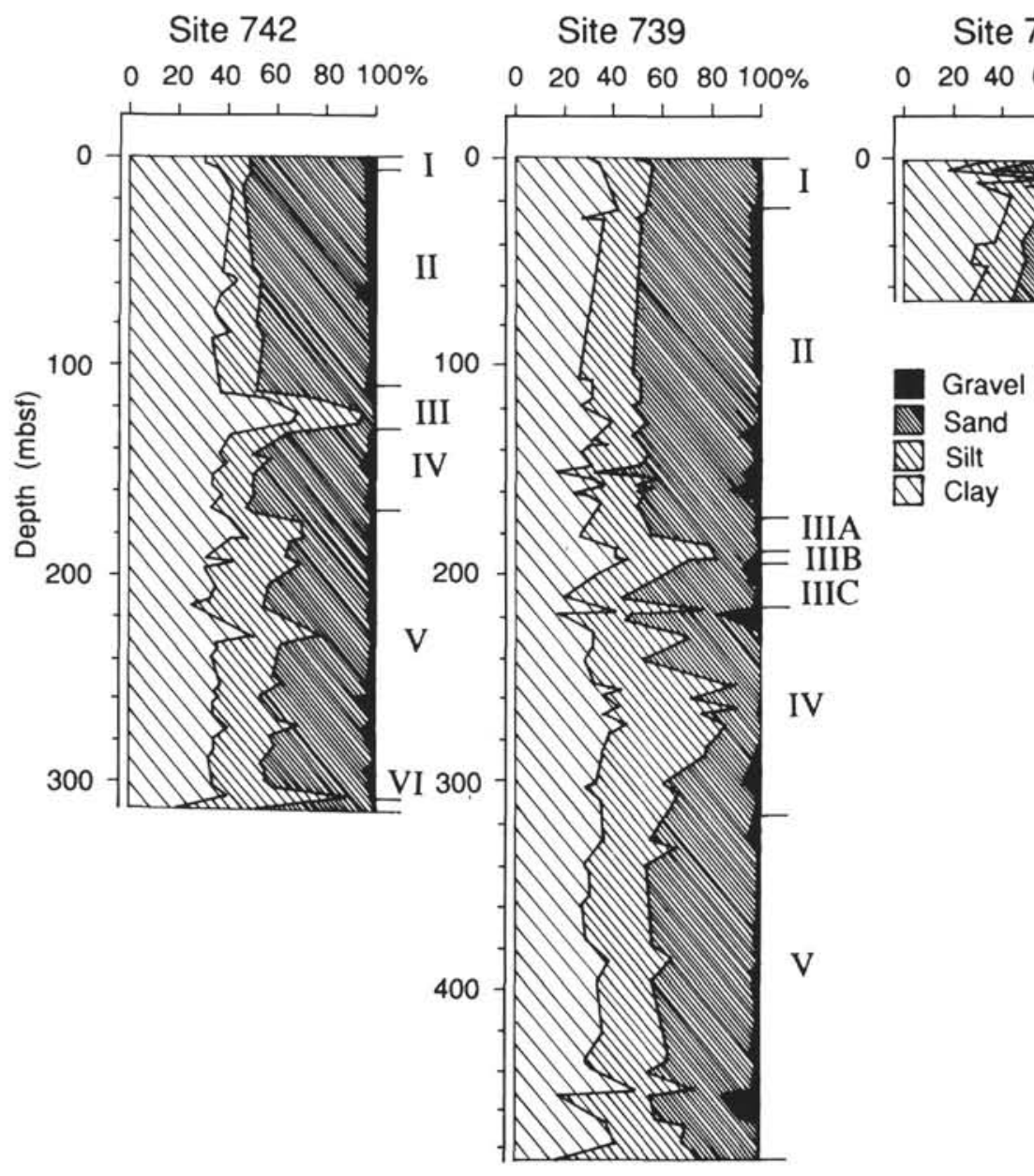

Figure 4. Distribution of clay, silt, sand, and gravel at Sites 739, 742, and 743. Lithostratigraphic units (I, II, etc.) are taken from Hambrey et al. (this volume). 
Site 739

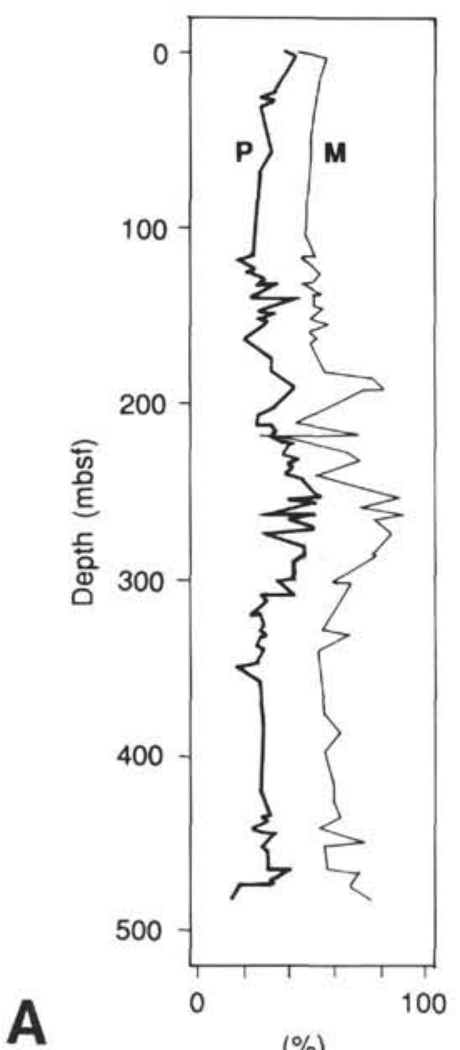

Site 742

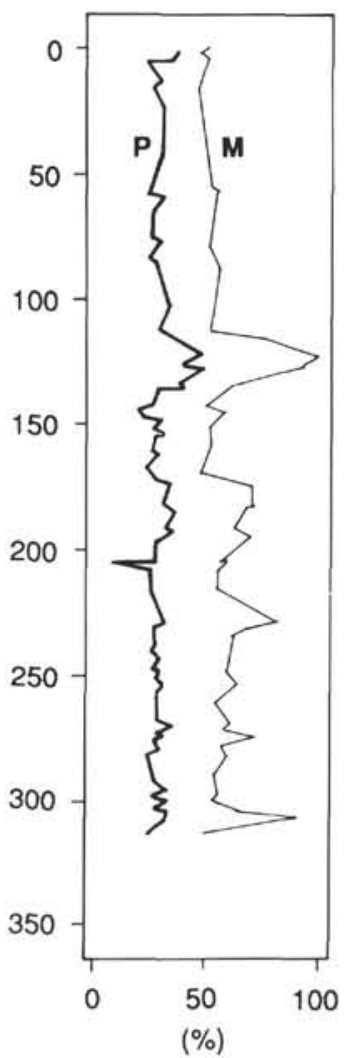

Site 743

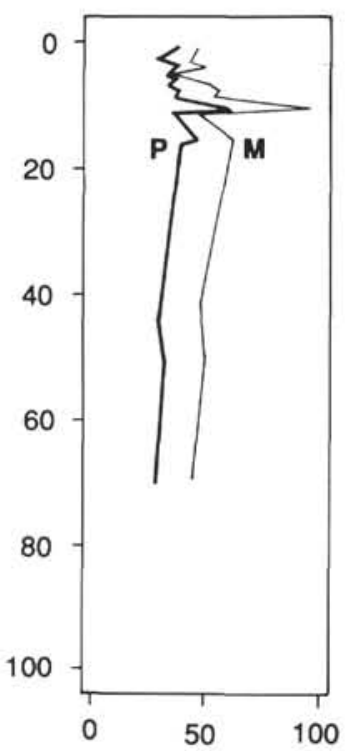

(\%)

Figure 5. A. Downhole plots of porosity (P) and clay + silt fractions (mud) (M) for Sites 739, 742, and 743. B. Plots of water content (percent of wet weight), porosity, wet-bulk density, and $P$-wave velocity versus the mud fraction for Sites 739, 742, and 743. Correlation coefficients (C) are shown on each plot.

a high percentage of material with $<0.063$-mm grain size (Fig. $5 \mathrm{~A})$. The thin layer of high porosity and water content in the diamictons of Site 743 also corresponds with a mud content of nearly $100 \%$ (Fig. 5A).

The fluctuating physical properties values thought possibly to be due to variations in consolidation (Shipboard Scientific Party, 1989b, 1989c) are therefore essentially grain-size effects. The overall values of the geotechnical properties are affected by a general overconsolidation (Solheim et al., chapter 9, this volume), but the variations superimposed on the low water content and porosity values and the high bulk-density values appear to be purely effects of lithologic variations. Undrained shear strength shows no correlation $(C)$ with the mud content $(C=0.02)$, and therefore no apparent shear strength variation was recorded in the high-porosity interval at Site 743 .

\section{Atterberg Limits}

As measurements of plastic and liquid limits were carried out only for the whole-round core samples, there are only results from a limited part of the cored sediments. The values are generally low (Fig. 6 and Table 2), with average values of $16.7 \%$ and $39.3 \%$ for plastic and liquid limits, respectively. These values, however, compare well with values measured in other glacial sediments from both on land (Boulton and Paul, 1976) and offshore (Lunne et al., 1986). At Site 739, there is a change to higher and more varied values of both plastic and liquid limits at around 150 mbsf. The sediments of Site 742 show uniform values of plastic limit in the analyzed interval, whereas the liquid limits have a raised value at 182 mbsf. Sites 740 and 743 have only one and two analyzed levels, respectively, with values of about $15 \%$ and $35 \%$ for the plastic and liquid limits, respectively. The plasticity index averages $22.5 \%$ for the total data set.

The natural water content (N.B.: now in percent of dry weight, "geotechnical water content") of the diamictite samples falls near or below the plastic limit for the diamictites, while it falls between the plastic and liquid limit for the diamictons of Sites 740 and 743 (Fig. 6). The Atterberg limits are merely functions of the amount and types of clay minerals present in the sample (Lambe and Whitman, 1979) and are unaffected by the stress history. Therefore, the relation between the natural water content and plasticity further illustrates the overconsolidated nature of the diamictites. The apparent change around 150 mbsf at Site 739 does not correspond to lithologic changes or changes in other physical properties, but may be explained by an increase in the smectite content, from values of $5 \%-10 \%$ to $10 \%-15 \%$ (Hambrey et al., this volume). A similar explanation can possibly be found for the peak liquid limit at Site 742 .

In a plasticity chart (Fig. 7), the bulk of the values falls well above the A-line, defined by Casagrande (1948) as dividing sediments of a broadly inorganic nature (above the line) from those with a significant organic content (below the line). According to Wagner (1957), the bulk of the samples would classify as an inorganic clay of low to medium plasticity. The two data points close to the A-line are Cores 119-739C-26R and 119-739C-30R. These samples have a raised clay and silt content relative to the remaining whole-round core samples and probably because of this also show different consolidation characteristics compared to the remaining samples (Table 2) (Solheim et al., chapter 9, this volume). 
Water content vs. mud fraction

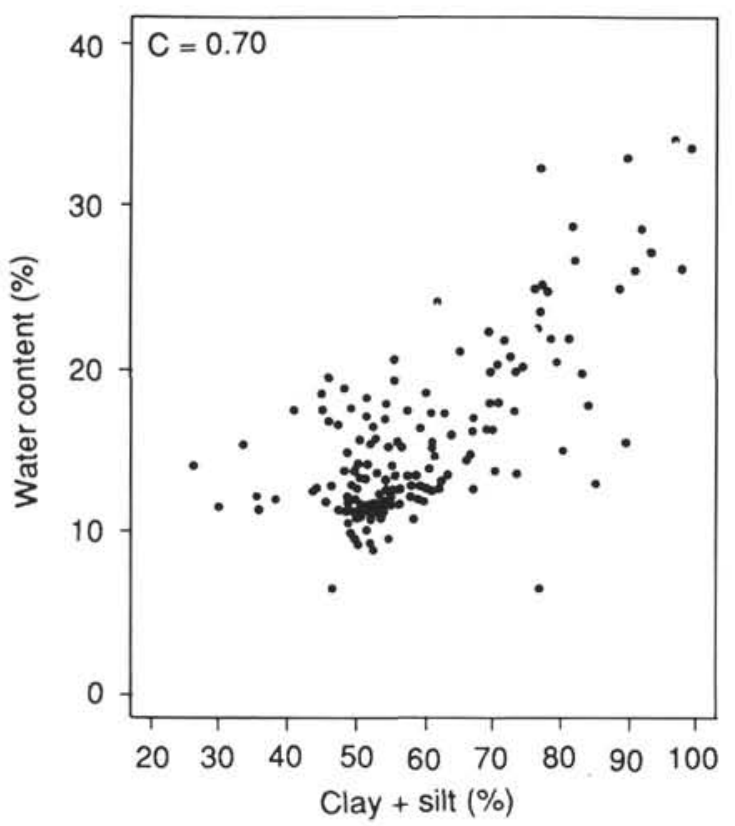

Bulk density vs. mud fraction

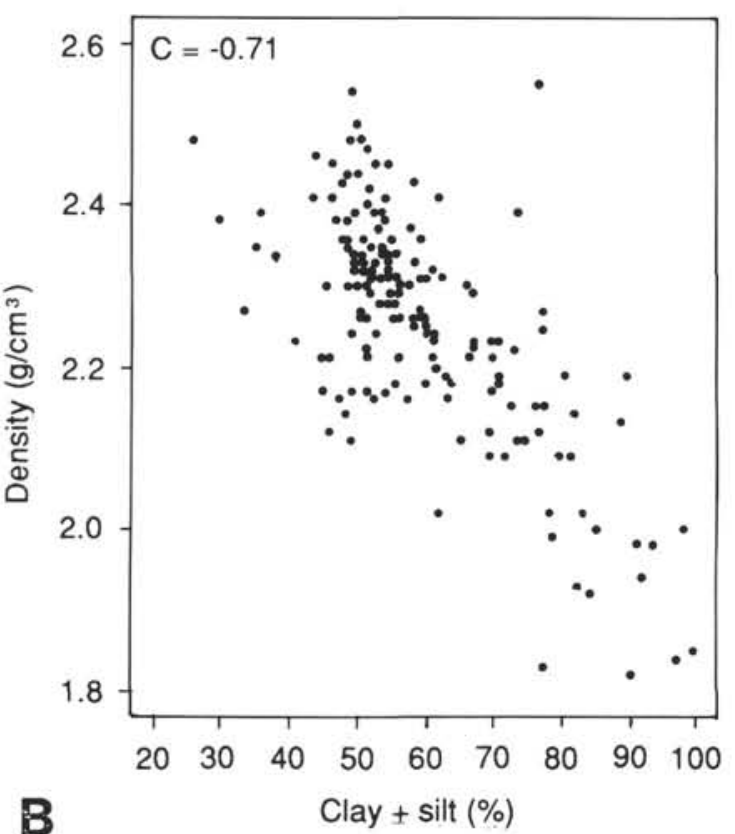

Figure 5 (continued).

Boulton and Paul (1976) defined a "T-line" (Fig. 7) for lodgement tills from Iceland and Spitsbergen. With the exception of the two samples close to the A-line, the majority of the tested samples plot at or very close to the T-line, in a position indicative of $>30 \%$ clay content, with a relatively high proportion of clay minerals rather than rock flour.

Activities (Skempton, 1953) of the tested samples show low values, around 0.6 (Fig. 8) and hence, the sediments classify as inactive. Low activities of clays typically are indications of a high content of rock flour in the fine fractions or a high content of inactive clay minerals as illite and kaolinite (Kazi and Knill,
Porosity vs. mud fraction

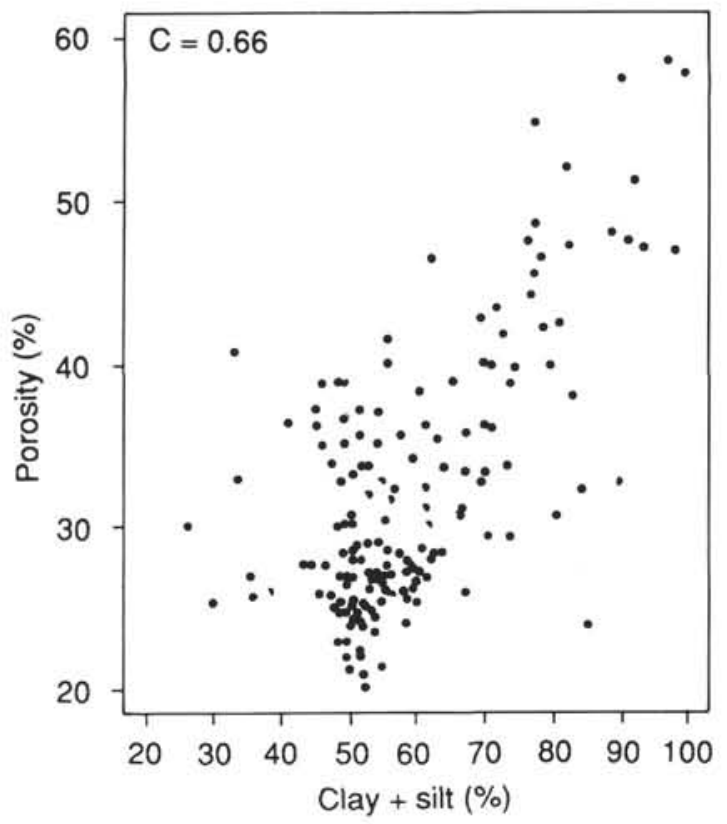

Velocity vs. mud fraction

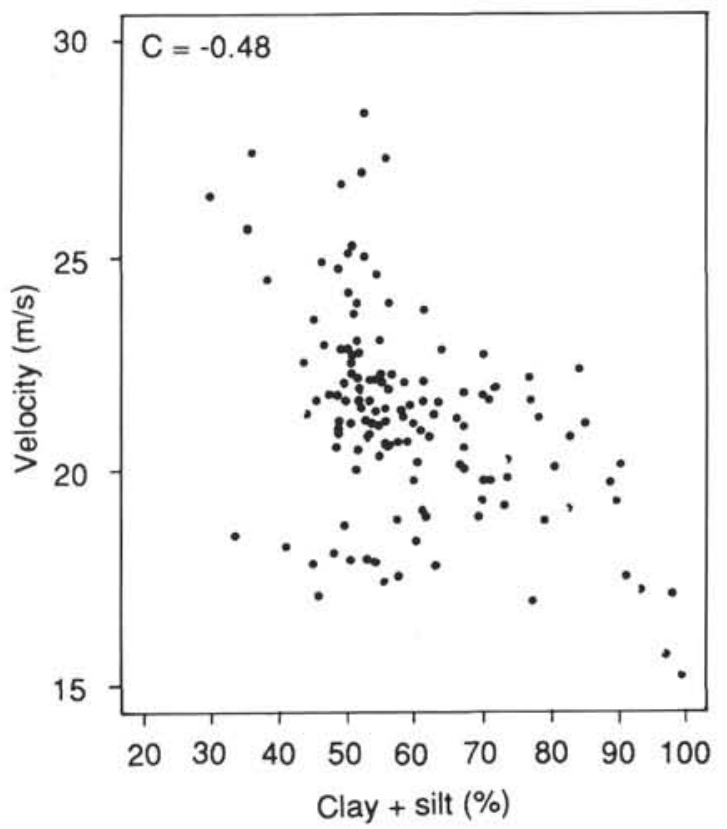

1969). From the position relative to Boulton and Paul's (1976) T-line, a predominance of rock flour in the clay fraction seems unlikely. This is further supported by Hambrey et al. (this volume) showing that the inactive minerals illite and kaolinite are the predominant clay minerals at both Sites 739 and 742 .

\section{Consolidation}

A total of 15 consolidation tests was carried out on samples of glacigenic sediments. The consolidation tests simulate the burial of sediments as the oedometer cell does not allow horizontal deformation to take place (Sandbaekken et al., 1986). 


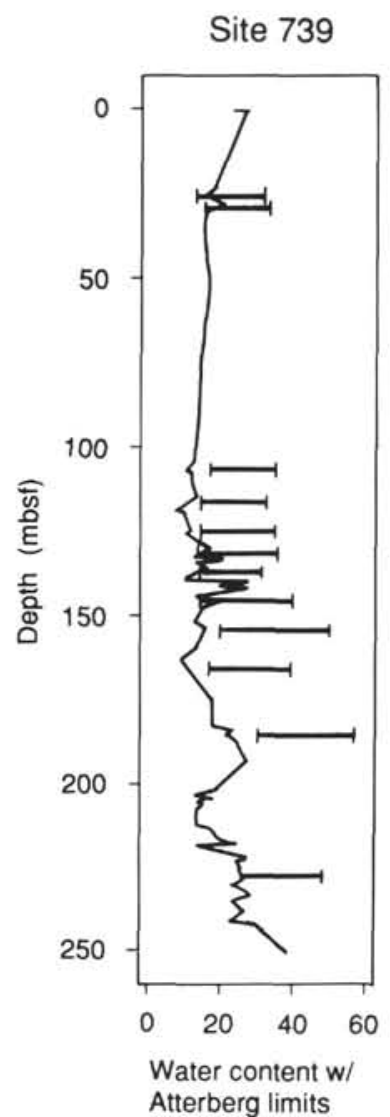

(\%)

Site 743

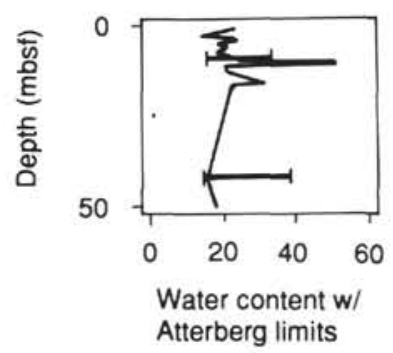

(\%)

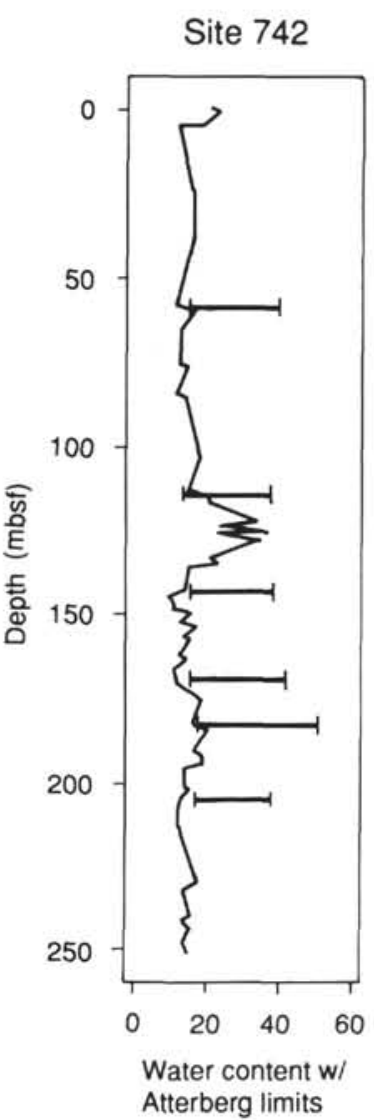

(\%)

Site 740

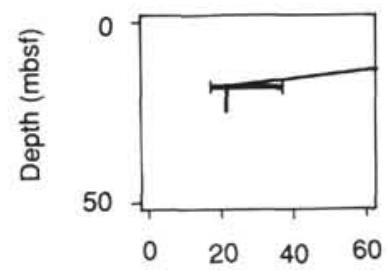

Water content w/ Atterberg limits

(\%)

Figure 6. Atterberg limits (plastic $=W_{p}$ and liquid $=W_{l}$ ) plotted on the natural water content for Sites 739, 740, 742, and 743. Note that all values are in percentage of dry weight, as opposed to the wet weight used elsewhere. This is done for the ease of comparison with other studies, as Atterberg limits are mostly given in percentage of dry weight.

Plots of the logarithm of vertical stress vs. void ratio (Fig. 9), or percent strain, as shown for the Prydz Bay samples by Solheim et al. (chapter 9, this volume) show two main parts, an initial linear, near-horizontal part and a linear sloping part. The former is due to reloading up to the highest previous stress level, whereas the latter represents loading beyond this and is often referred to as the virgin compression curve. The virgin compression curve is ideally linear for a given sediment and can be used to compare different deposits. Different stress histories will not change the virgin compression curve but only the transitional

zone between the recompression and virgin compression curves at about the preconsolidation stress $\left(P_{c}{ }^{\prime}\right)$. The linearity of the virgin compression curve allows defining two parameters from the equation (Atkinson and Bransby, 1978),

$$
e=e_{o}-\lambda \ln (\sigma)
$$

where $e_{o}$ is the void ratio at $\ln (\sigma)=0$ or $\sigma=1 \mathrm{kPa}$ and $\lambda$ is the slope of the line.

These parameters define the consolidation characteristics for a given sediment. The parameters calculated for the Prydz Bay diamictons are listed in Table 2 . It should be noted, however, that the validity of the equation is limited at extrapolations to high vertical stresses, as for such conditions it implies negative void ratios. The results from the measurements performed in this study, however, show that the curves are still nearly linear at the end of the test at approximately $24,000 \mathrm{kPa}$. This linearity is a prerequisite for the use of geotechnical consolidation theory,

A comparison of the results found here with data compiled by Jones and Addis (1985) shows that most of the samples have a virgin compression curve that is near or beyond the lower extreme of both the $e_{o}$ and $\lambda$ ranges. Exceptions are the results from the more fine-grained intervals (e.g., Samples 119-739C26R-2, 140-145 cm, and 119-739C-30R-5, 19-24 cm). Jones and Addis (1985) maintained that sediments with high amounts of nonclay minerals (e.g., rock flour) will be expected to show such behavior. Most likely, inactive clay minerals such as illite or kaolinite will behave similarly.

The results and interpretation of the consolidation tests with reference to $P_{c}{ }^{\prime}$ are discussed by Solheim et al. (chapter 9, this volume), and only the main results are summarized here. At Site 739 , all oedometer-tested samples (down to $228 \mathrm{mbsf}$ ) were overconsolidated, with overconsolidation ratios (OCR) varying from 2 to 6 (Table 2). Measured preconsolidation stresses $\left(P_{c}^{\prime}\right)$ up to $10,000 \mathrm{kPa}$ were measured in the lowermost tested samples, at 228 mbsf. A stepwise downhole increase in $P_{c}{ }^{\prime}$ is ascribed to glacial loading and past sediment loads, subsequently removed by extensive glacial erosion across the shelf (Solheim et al., chapter 9 , this volume).

Similar values of $P_{c}{ }^{\prime}$ are found at Site 742, with the exception of a close to normally consolidated level at $113.5 \mathrm{mbsf}$ (Table 2). The four separate steps in the $P_{c}{ }^{\prime}$ values are correlated between Sites 739 and 742 (Solheim et al., chapter 9, this volume). Single consolidation tests in the soft diamictons of Sites 740 and 743 showed essentially normally consolidated sediment. Exact values of OCR for these two samples are 1.3 and 0.8 , respectively, but because of a generally poor core recovery, and, hence, difficulties in estimating in-situ stress $\left(P_{o}{ }^{\prime}\right)$, the uncertainties are great.

The validity of the interpretation of the consolidation tests also depends on the uncemented nature of the sediments. Both shipboard inspection (Barron, Larsen, et al., 1989) and shorebased geochemical analyses indicate that the tested samples are uncemented.

\section{Permeability}

Permeabilities were estimated both from the consolidation tests and as measured in the oedometer and in triaxial cell. Despite a wide range of variation (Table 2 ), values of the coefficient of permeability $(k)$ are generally low, averaging $0.004 \mathrm{~m} /$ yr. The maximum and minimum values are 0.036 and $0.0003 \mathrm{~m} /$ yr, respectively. According to the classification by Terzaghi and Peck (1967), this is representative of very low permeability to practically impermeable. The number of $k$ values measured or estimated for the normally consolidated diamictons is too sparse to be conclusive on variations in the permeability with degree of 
Table 2. Results of the land-based laboratory analyses of the whole-round core samples.

\begin{tabular}{|c|c|c|c|c|c|c|c|c|c|c|c|c|c|c|c|c|c|}
\hline $\begin{array}{l}\text { Core, section } \\
\text { interval }(\mathrm{cm})\end{array}$ & $\begin{array}{l}\text { Depth } \\
\text { (mbsf) }\end{array}$ & Test $^{\mathrm{a}}$ & $\begin{array}{c}P_{O^{\prime}}^{\prime} \\
(\mathrm{kPa})\end{array}$ & $\begin{array}{l}P_{c^{\prime}} \\
(\mathrm{kPa})\end{array}$ & OCR & $\begin{array}{c}k \\
(\mathrm{~m} / \mathrm{yr})\end{array}$ & $\begin{array}{c}S_{u} \\
(\mathrm{kPa})\end{array}$ & $e_{o}$ & $\lambda$ & $\begin{array}{l}W_{p} \\
(\%)\end{array}$ & $\begin{array}{l}W_{l} \\
(\%)\end{array}$ & $\begin{array}{c}I_{p} \\
(\%)\end{array}$ & $\begin{array}{l}W_{n} \\
(\%)\end{array}$ & $\begin{array}{l}\text { Clay } \\
(\%)\end{array}$ & $\begin{array}{l}\text { Silt } \\
(\%)\end{array}$ & $\begin{array}{l}\text { Sand } \\
(\%)\end{array}$ & $\begin{array}{c}\text { Gravel } \\
(\%)\end{array}$ \\
\hline \multicolumn{18}{|l|}{$119-739 \mathrm{C}-$} \\
\hline $4 R-3,0-15$ & 27.10 & Triax & 286 & (4370) & $(15.3)$ & & 660 & & 13 & 31 & 18 & 17 & 34.4 & 17.7 & 47.3 & 0.6 & \\
\hline $5 \mathrm{R}-1,94-99$ & 29.64 & Cons & 335 & 2000 & 6.0 & 0.015 & (430) & 0.50 & 0.036 & 15 & 33 & 18 & 16 & 37.0 & 13.0 & 48.8 & 1.3 \\
\hline $13 \mathrm{R}-1,140-150$ & 107.30 & Cons & 1410 & 2900 & 2.1 & 0.0008 & (750) & 0.66 & 0.043 & 17 & 35 & 18 & 11 & 31.1 & 18.3 & 49.8 & 0.8 \\
\hline $13 \mathrm{R}-1,140-150$ & 107.30 & DSS & 1410 & (2820) & (2.0) & & 714 & & 0.043 & 17 & 35 & 18 & 11 & 31.1 & 18.3 & 49.8 & 0.8 \\
\hline $14 \mathrm{R}-2,60-65$ & 117.60 & Cons & 1511 & 6200 & 4.1 & 0.0006 & (1360) & 0.53 & 0.037 & 14 & 32 & 18 & 10 & 30.5 & 15.9 & 50.9 & 2.7 \\
\hline $15 \mathrm{R}-1,119-124$ & 126.39 & Cons & 1596 & $6000(?)$ & 3.8 & 0.0015 & (1440) & 0.54 & 0.034 & 14 & 35 & 21 & 10 & 39.3 & 15.3 & 44.5 & 0.9 \\
\hline $16 \mathrm{R}-1,135-150$ & 131.65 & Triax & 1670 & $(7350)$ & (4.4) & & 1709 & & 14 & 35 & 21 & 14 & 35.6 & 14.5 & 47.6 & 2.3 & \\
\hline $17 \mathrm{R}-2,145-150$ & 137.95 & Cons & 1748 & 7000 & 4.0 & 0.0003 & (1540) & 0.56 & 0.036 & 14 & 32 & 18 & 13 & 36.0 & 18.1 & 43.9 & 1.9 \\
\hline $19 \mathrm{R}-1,135-150$ & 146.05 & Triax, Perm & 1845 & (10150) & (5.5) & 0.000314 & 2488 & & 14 & 40 & 26 & 19 & 31.2 & 24.5 & 43.4 & 1.0 & \\
\hline $21 \mathrm{R}-1,18-23$ & 154.48 & Cons & 1951 & 8000 & 4.1 & 0.002 & (1930) & 0.94 & 0.068 & 20 & 49 & 29 & 17 & 33.9 & 22.6 & 41.1 & 2.3 \\
\hline $23 \mathrm{R}-2,31-36$ & 165.81 & UCT & & & & & & & & 17 & 39 & 22 & 10 & 40.1 & 14.8 & 43.5 & 1.6 \\
\hline $26 \mathrm{R}-2,140-145$ & 186.10 & Cons & 2334 & 8200 & 3.5 & 0.005 & (1980) & 3.02 & 0.25 & 30 & 57 & 27 & 21 & 51.1 & 32.7 & 16.2 & 0.0 \\
\hline $30 \mathrm{R}-5,19-24$ & 227.99 & Cons & 2829 & 10000 & 3.5 & 0.0015 & (2350) & 2.64 & 0.22 & 26 & 48 & 22 & 27 & 32.5 & 32.6 & 33.0 & 1.9 \\
\hline \multicolumn{18}{|l|}{$119-740 \mathrm{~A}-$} \\
\hline $3 R-3,145-150$ & 18.15 & Cons & 80 & 100 & 1.3 & 0.036 & (30) & 0.95 & 0.074 & 17 & 37 & 20 & 21 & 35.6 & 21.8 & 40.5 & 2.1 \\
\hline \multicolumn{18}{|l|}{$119-741 \mathrm{~A}-$} \\
\hline $5 R-2,91-96$ & 35.91 & Cons & 420 & $>10000$ & $>24$ & $0.02(?)$ & $(>1800)$ & & & 12 & 48 & 36 & 15 & 41.9 & 43.6 & 14.4 & 0.1 \\
\hline $6 \mathrm{R}-1,78-83$ & 43.98 & Cons & 483 & $>10000$ & $>21$ & 0.00007 & $(>2030)$ & & & 22 & 62 & 40 & 15 & 37.6 & 36.2 & 26.2 & 0.0 \\
\hline $10 \mathrm{R}-2,63-68$ & 84.03 & Cons & 964 & $>10000$ & $>10$ & 0.0002 & $(>1740)$ & & & 22 & 48 & 26 & 13 & 58.6 & 32.9 & 8.45 & 0.0 \\
\hline \multicolumn{18}{|l|}{$119-742 \mathrm{~A}-$} \\
\hline $8 \mathrm{R}-2,86-91$ & 57.86 & Cons & 705 & 2000 & 2.8 & 0.003 & $(510)$ & 0.66 & 0.046 & 15 & 40 & 25 & 12 & 37.7 & 15.4 & 45.73 & 1.2 \\
\hline $14 \mathrm{R}-1,21-26$ & 113.51 & Cons & 1390 & 2000 & 1.4 & 0.007 & (560) & 0.69 & 0.048 & 14 & 37 & 23 & 15 & 37.1 & 13.7 & 46.2 & 3.0 \\
\hline $17 \mathrm{R}-1,49-54$ & 142.79 & Cons & 1639 & $6000(?)$ & 3.7 & 0.002 & (1440) & 0.61 & 0.040 & 15 & 39 & 24 & 15 & 35.8 & 13.9 & 47.7 & 2.6 \\
\hline $19 \mathrm{R}-5,33-138$ & 169.03 & UCT & & & & & & & & 16 & 42 & 26 & 12 & 33.1 & 14.2 & 47.9 & 4.8 \\
\hline $21 \mathrm{R}-2,0-5$ & 182.50 & Cons & 2115 & 7500 & 3.5 & 0.0003 & (1900) & 0.91 & 0.065 & 19 & 51 & 32 & 17 & 48.1 & 21.6 & 28.0 & 1.7 \\
\hline $23 \mathrm{R}-3,102-107$ & 204.32 & Cons & 2446 & 9000 & 3.7 & 0.0012 & $(2150)$ & 1.00 & 0.077 & 17 & 38 & 21 & 14 & 35.2 & 23.5 & 37.5 & 3.8 \\
\hline \multicolumn{18}{|l|}{$119-743 \mathrm{~A}=$} \\
\hline $4 \mathrm{H}-3,135-150$ & 8.95 & Triax, Perm & 104 & (177) & (1.7) & 0.0017 & 47.4 & & & 15 & 34 & 19 & 20 & 34.3 & 17.7 & 43.5 & 4.5 \\
\hline $9 X-1,145-150$ & 40.20 & Cons & 502 & 400 & 0.8 & 0.002 & (130) & 0.74 & 0.055 & 15 & 39 & 24 & 16 & 36.6 & 10.6 & 48.4 & 4.4 \\
\hline
\end{tabular}

Notes: $P_{o}{ }^{\prime}=$ effective in-situ stress; $P_{c^{\prime}}=$ preconsolidation stress (values in parentheses are estimated from DSS and triaxial test results); OCR = overconsolidation ratio (values in parentheses are estimated from the DSS and triaxial test results); $k=$ Darcy's coefficient of permeability; $S_{u}=$ undrained shear strength (values in parentheses are estimated from oedometer test results); $e_{o}=$ initial void ratio, from extrapolating the virgin compression curves of the oedometer tests; $\lambda=$ slope of the virgin compression curves of the oedometer tests; $W_{p}=$ plastic limit; $W_{l}=$ liquid limit; $I_{p}=$ plasticity index; $W_{n}=$ natural water content in percent of dry weight.

${ }^{\text {a }}$ See Table 1 for explanation of laboratory test performed. 


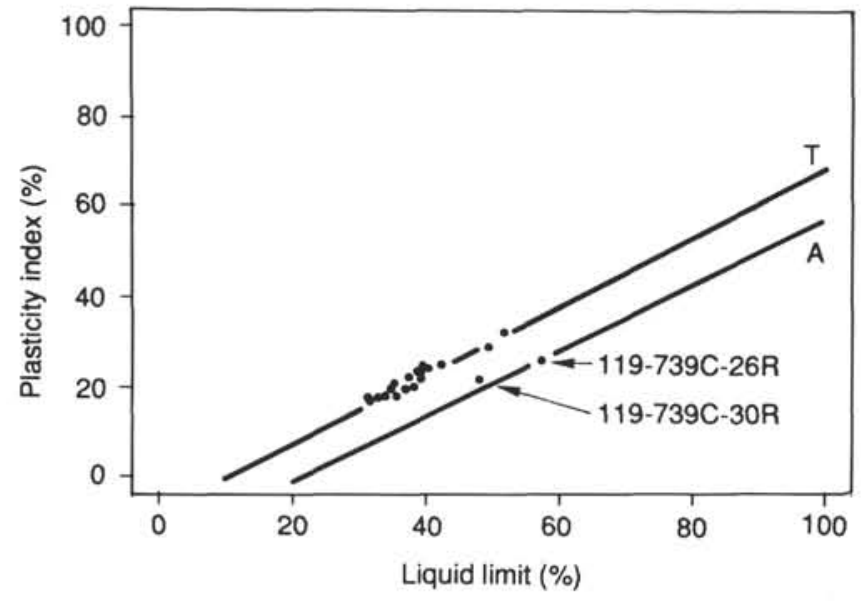

Figure 7. Plasticity chart for the glacigenic sediments. Boulton and Paul's (1976) T-line and Casagrande's (1948) A-line are shown.

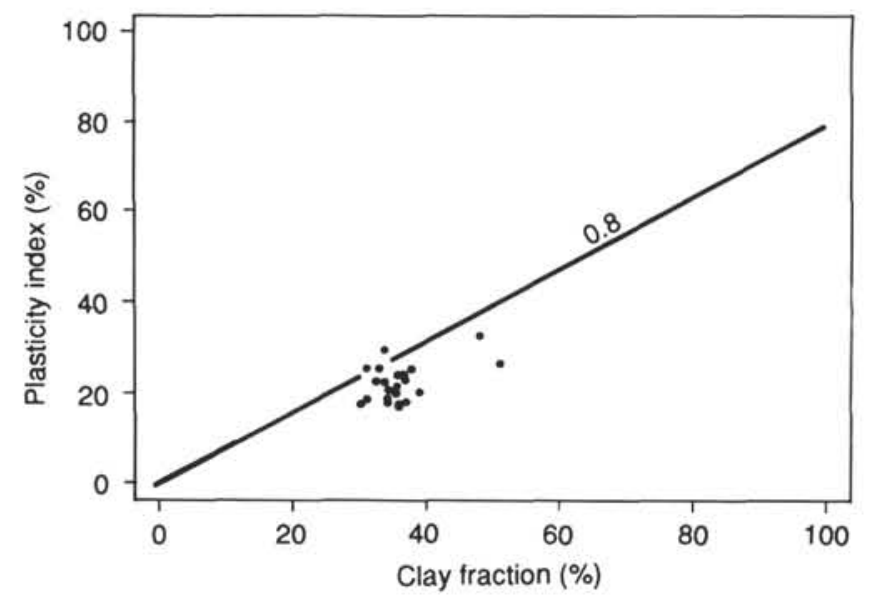

Figure 8. Activity chart for the glacigenic sediments. The line with slope 0.8 marks the division to inactive sediments (below) (Skempton, 1953).

consolidation. The test of the normally consolidated Sample $119-740 \mathrm{~A}-3 \mathrm{R}-3,145-150 \mathrm{~cm}$, shows the highest $k$ value, 0.036 $\mathrm{m}$ /year, which is still very low, even for glacial tills (Terzaghi and Peck, 1967; Chilingarian and Wolf, 1975). On the other hand, the shallowest sample at Site 743 , as measured in triaxial cell, showed $0.0017 \mathrm{~m} / \mathrm{yr}$, which is lower than several of the overconsolidated samples. In general, the permeability will decrease considerably more rapidly than porosity with increasing degree of consolidation (Lambe and Whitman, 1979; Bryant et al., 1981). On the other hand, the grain-size distribution of the sample is generally the most important single parameter determining the permeability. Plots of permeability vs. clay content and preconsolidation stress $\left(P_{c}{ }^{\prime}\right)$ (Fig. 10) show that for the material in this study there is no correlation between the clay content and the permeability, whereas the latter correlates better with $P_{c}{ }^{\prime}$. This is probably also a function of the character of the clay fraction, most likely with a relatively high proportion of nonclay minerals.

\section{Undrained Shear Strength}

In the bulk of the cored diamictites, the undrained shear strength exceeded the approximately $900-\mathrm{kPa}$ capacity of the shipboard pocket penetrometer. The strengths measured close to this value are uncertain because of fracturing of the sample dur-

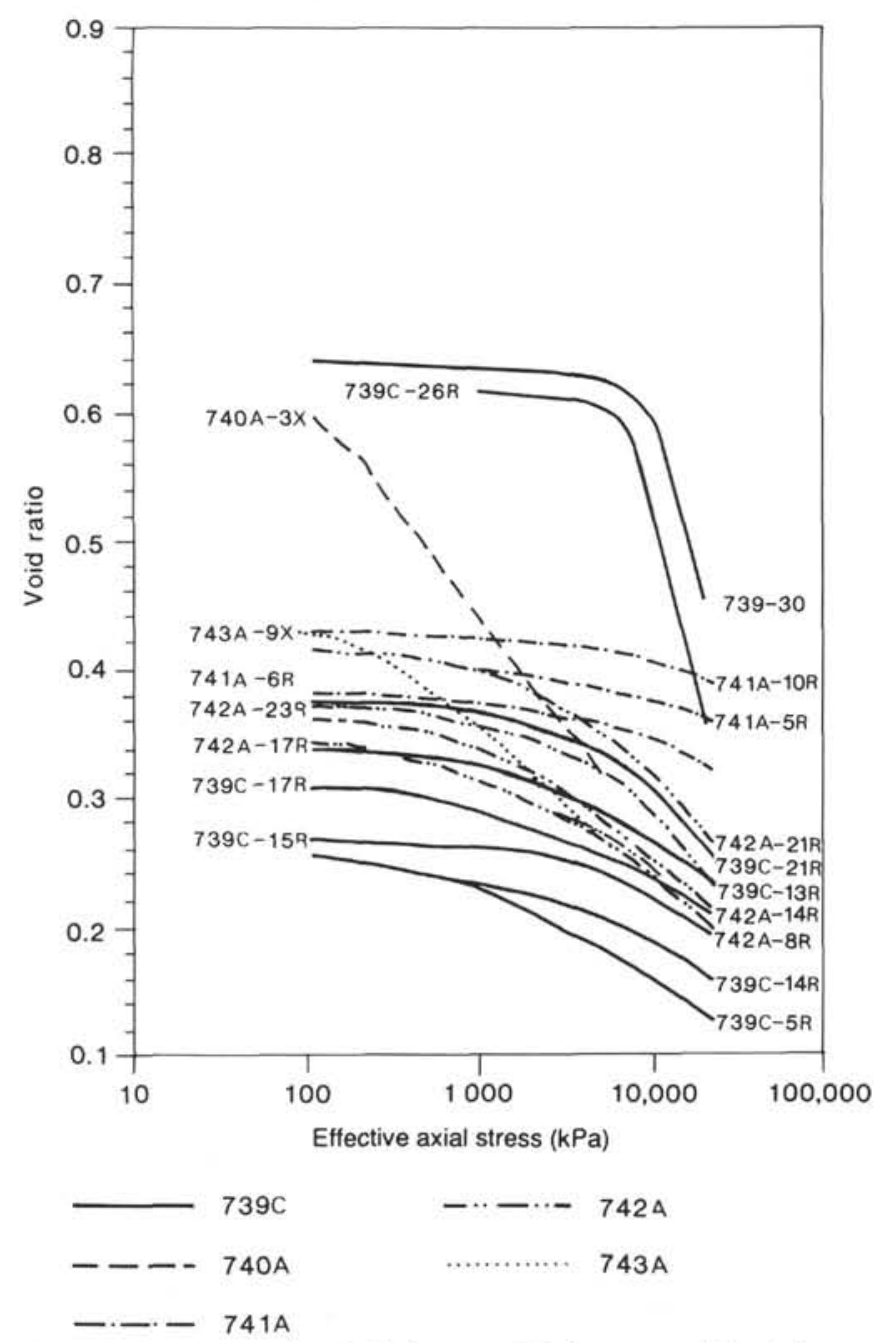

Figure 9. Composite plot of all the consolidation tests, with axial stress plotted against void ratio. Unload-reload loops are omitted for clarity of the figure. From Solheim et al. (chapter 9, this volume).

ing push-in, and they should be taken only as indications of high-strength material. Three laboratory triaxial tests and one simple shear test were carried out to measure undrained shear strengths in the overconsolidated diamictites, whereas one triaxial test was carried out on a presumably normally consolidated sample from Site 743 (Table 2 and Fig. 11A).

In the simple shear test of Sample 119-739C-13R-1, 140-150 $\mathrm{cm}$, from $107.3 \mathrm{mbsf}$, failure was achieved at $720 \mathrm{kPa}$ (Fig. $11 \mathrm{~A})$, which is comparable with the shipboard values. Of the triaxial tests of diamictites, the shear stress peaked only in the deepest sample, 119-739C-19R-1, 135-150 cm, at a value close to $2500 \mathrm{kPa}$ (Fig. 11B). For Samples 119-739C-4R-3, 0-15 cm, and $119-739 \mathrm{C}-16 \mathrm{R}-1,135-150 \mathrm{~cm}$, the shear stress continued to rise towards strains as high as $20 \%$ and no failure occurred (Fig. 11B). In accordance with experience for similar material from offshore Norway (T. Lunne, pers. comm., 1989), the value for undrained shear strength was picked at $10 \%$ axial strain, giving 660,1709 , and $2488 \mathrm{kPa}$ for the samples with increasing downhole depth (Fig. 11B and Table 2).

The same procedure was used for the soft diamicton Sample $119-743 \mathrm{~A}-4 \mathrm{H}-3,135-150 \mathrm{~cm}$, giving a shear strength value of 47 $\mathrm{kPa}$, although the curve for this test peaks $49 \mathrm{kPa}$ at $17 \%$ axial strain (Fig. 11A). A value of $40-50 \mathrm{kPa}$ for this sample is in ac- 
Permeability vs. clay content

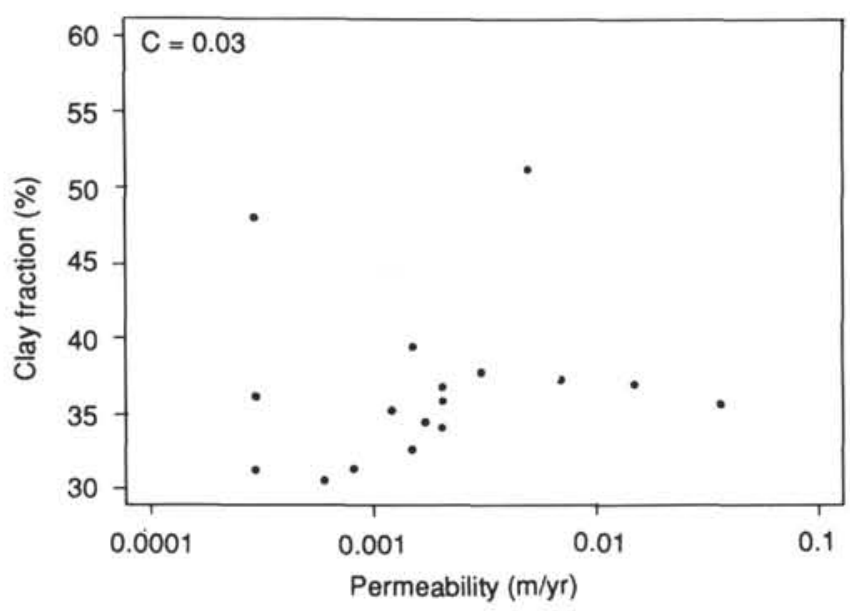

Permeability vs. Pc'

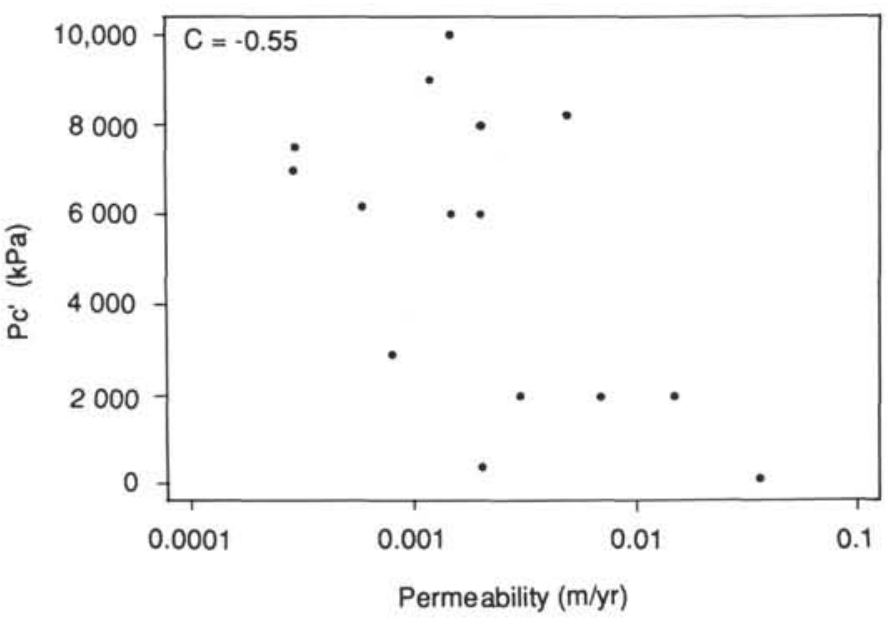

Figure 10. Clay fraction $(\%)$ and preconsolidation stress $\left(P_{c}{ }^{\prime}\right)$ plotted against permeability for the glacigenic sediments. Correlation coefficients $(\mathrm{C})$ are indicated.

cordance with the shipboard values obtained by fall-cone penetrometer (Barron, Larsen, et al., 1989), confirming the normally consolidated nature of the sediment at this depth.

For the stiff diamictite samples, the triaxial shear-strength value in the shallowest sample, at 27.1 mbsf, corresponds reasonably well with the shipboard values measured by pocket penetrometer in adjacent sections within an error range of $200 \mathrm{kPa}$ for the latter instrument (Table 2 and Appendix). The two deepest triaxial tests give values well beyond the range of the shipboard devices.

The continued rise in the stress-strain curves for the triaxial tests of Samples 119-739C-4R-3, 0-15 cm, and 119-739C-16R-1, $135-150 \mathrm{~cm}$ (Fig. 11A), is probably best explained by the negative pore pressures developed during the test (Fig. 11B). This again results from a tendency toward a volume increase during the shearing of overconsolidated clays (Lambe and Whitman, 1979). This tendency, causing increasing effective stresses, may continue to high strains and therefore cause the continuous rise of the stress-strain curves.
The stress paths for the triaxial and direct shear (DSS) tests (Fig. 11C) give the strength parameters $c$ (cohesion) and $\phi$ (friction angle) for the tested sediments. The stress paths for the samples that showed no failure apparently rise subparallel to the failure line. Therefore, fitted straight lines can be drawn along these and through the failure points for samples of the same sediment type (Fig. 11C). From this procedure, Sample 119$739 \mathrm{C}-19 \mathrm{R}-1,135-150 \mathrm{~cm}$, appears to have characteristics different from the remaining four samples (Fig. 11C), mainly in having a higher cohesion, although more tests are needed to define the curve. Most likely, the difference results from lithologic differences. A slightly higher mud content than the other samples, also resulting in a slightly higher plasticity (Table 2 ), is a possible explanation. However, more tests are required to verify that significantly (geotechnically) different sediments were present.

\section{Indirect Estimates of $\mathrm{OCR}$ and Undrained Shear Strength}

Sample disturbance may strongly influence the shape of the consolidation curves from oedometer tests and tends to cause an underestimate of $P_{c}{ }^{\prime}$, particularly for heavily overconsolidated samples (Andresen et al., 1979). As undrained shear strength for clays is assumed to be less influenced by sample disturbance, a procedure based on empirical relations between plasticity, undrained shear strength, and in-situ stress $\left(P_{o}{ }^{\prime}\right)$ (Andresen et al., 1979; Brooker and Ireland, 1965) was used to estimate $P_{c}^{\prime}$ (Fig. 12).

Four $P_{c}^{\prime}$ values were estimated this way at Site 739 , using the undrained shear strength values from the DSS and triaxial tests (Table 2). The shallowest, at $27.1 \mathrm{mbsf}$, is approximately twice the value of the oedometer test $2.5 \mathrm{~m}$ farther downhole, and hence may indicate an underestimation of $P_{c}{ }^{\prime}$ from the oedometer tests (Solheim et al., chapter 9, this volume) in this part of the drilled sequence. The $P_{c}{ }^{\prime}$ estimated from the direct shear test at 107.30 mbsf (Table 2) has an almost perfect fit with the oedometer test performed on another part of the same $10-\mathrm{cm}-$ long sample, giving some indication that the character of the specific sample analyzed may have an influence (e.g., lithology). Another test at 131.65 mbsf also matches well with adjacent consolidation test results, whereas the deepest triaxial test at this site results in an estimated $P_{c}^{\prime}$ significantly higher than the adjacent ones from oedometer tests (Table 2 ). This may again indicate underestimates of $P_{c}{ }^{\prime}$ from the oedometer tests, but because the procedure used here is based on empirical relations calculated from sediments different from the ones of the present study, the uncertainties may be considerable. Important though, for all these estimated values is that they show that the oedometer consolidation tests give a realistic estimate for the consolidation, on the conservative side rather than giving too high values.

The $P_{c}{ }^{\prime}$ value estimated from the triaxial test of the apparently normally consolidated diamicton at Site 743 (Table 2) indicates a slight overconsolidation, which could be real, caused by secondary compression (creep) or gravity-induced removal of overburden at a relatively small scale. For most practical reasons, however, and considering the uncertainties in the estimates, the sediment can be considered normally consolidated.

The same empirical relations (Fig. 12) were also used to estimate undrained shear strength from the consolidation test results, reversing the procedure previously discussed. At Site 739, undrained shear strength values obtained this way are lower than the shipboard-measured values in the upper $110 \mathrm{mbsf}$ (Table 2). Although great care should be taken in using undrained shear strength values obtained by pocket penetrometer near the upper limit of the measurable range for this instrument, the difference in estimated and measured values may give further indications of the underestimated $P_{c}{ }^{\prime}$ values from the oedometer 

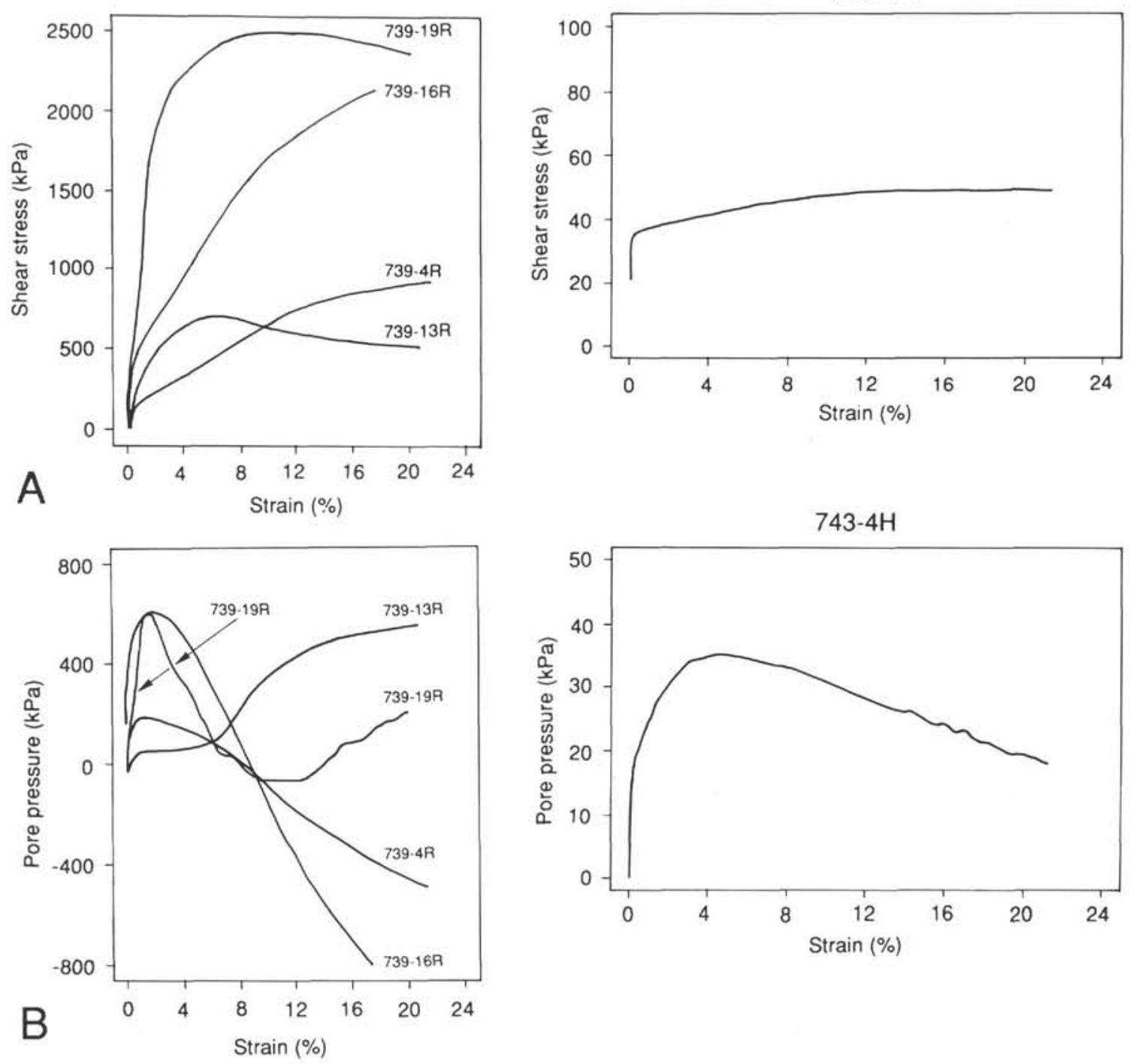

Figure 11. A. Stress-strain curves for the triaxial and simple shear (739-13) tests. Note the different scale used for the normally consolidated sample from Site 743 (right diagram). B. Pore pressure during the triaxial and simple shear (739-13) tests. Note the different scale used for the sample from Site 743 (right diagram). C. Stress paths for the triaxial and simple shear (739-13) tests. Tentative failure lines are stippled and estimated values of cohesion $(c)$ and friction angle $(\phi)$ are indicated.

tests, possibly caused by sample disturbance. Farther downhole the sediment was generally too stiff for shipboard measurements, and no comparison is possible although the high triaxial undrained shear strength at $\mathbf{1 4 6 . 0 5} \mathrm{mbsf}$, compared to those undrained shear strengths obtained from the $P_{c}{ }^{\prime}$ values, may indicate the same.

For the two oedometer-tested diamicton samples at Sites 740 and 743 , the estimated undrained shear strength values fall within the range of adjacent values measured with the shipboard equipment.

At Site 742 , there is a relatively great scatter in the shipboard undrained shear strength values (Barron, Larsen, et al., 1989) (Appendix), and the two shallowest of the values estimated from $P_{c}{ }^{\prime}$ (at 57.86 and $113.51 \mathrm{mbsf}$ ) (Table 2) fall within the range of this scatter. Below this, the estimated shear strengths exceed the upper limit for the shipboard devices, and shipboard values within the measurable range may have been affected by drilling disturbance.

\section{DISCUSSION}

The results of the land-based laboratory studies have shown that the geotechnical character of the glacigenic sediments on the continental shelf in Prydz Bay is a function of a general but varying degree of overconsolidation and lithologic variations. The relatively high overconsolidation ratios (OCR) from oedometer tests show stepwise downhole trends, interpreted to represent mostly the effects of sediment loading followed by periods of large-scale glacial erosion by the East Antarctic Ice Sheet during expanded phases (Solheim et al., chapter 9, this volume). However, the steps in consolidation show no correspondence to more high-frequency fluctuations in other physical properties, which do show good correspondence with the grain-size distributions (Fig. 5). The latter is therefore taken as the principal cause for the fluctuating physical properties, particularly in the intervals between 170 and 310 mbsf at Site 739 and between 114 and 195 mbsf at Site 742 . 


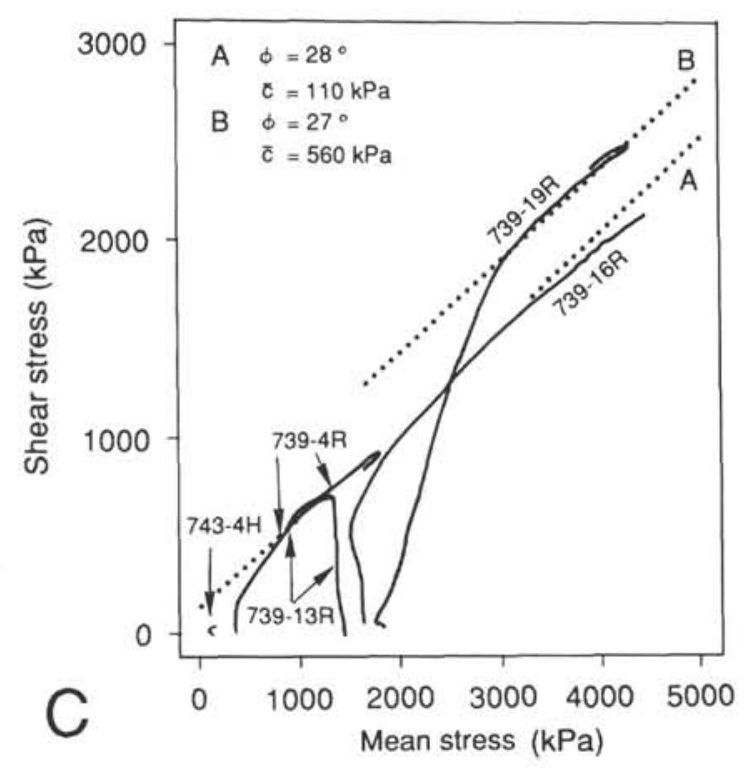

Figure 11 (continued).

The consolidation history as interpreted by Solheim et al. (chapter 9, this volume) provides information on the largescale, long-term expansions and retreats of the ice sheet that removed major parts of the sedimentary record, created large hiatuses, and left only remnants of the glacial history (Barron, Larsen, et al., 1989). Probably the most important factor affecting the grain-size distribution, and therefore also the smaller-scale variations in physical properties, is the distance from the sediment source (i.e., the proximity to the glacier grounding line). Grounding-line fluctuations of considerably higher frequencies than that apparent from the consolidation history (Solheim et al., chapter 9, this volume) are evident from the physical properties variations. High values of porosity and water content and low values of bulk density and velocity indicate a more distal position relative to the grounding line. Because of the long hiatuses and the poor chronostratigraphic control (Barron, Larsen, et al., 1989), any attempt to count individual advances and retreats would be misleading. A number of such relatively shortterm fluctuations are most likely hidden in the hiatuses, as well as in non-recovered parts of the sedimentary section. Furthermore, there is a notable lack of sediments interpreted as glacier distal in the recovered sequences (Hambrey et al., this volume). Although distal sedimentation may be low on the Antarctic continental shelf (Elverhøi and Roaldset, 1983), a likely explanation is that the distal deposits are the first to be eroded by subsequent advances. Through a number of advances and retreats, mostly proximal sediments, lodgement tills, and reworked distal deposits are preserved.

The Shipboard Scientific Party (1989b, 1989c) speculated whether the smaller scale fluctuations in physical properties could be ascribed to variations in consolidation. The results of the oedometer tests can be used to check the probability of this. At Site 739 , the porosity decreases from approximately $40 \%$ to $25 \%$ between 186 and 205 mbsf. This implies a void ratio reduction of 0.33. The consolidation test of Sample 119-739C-26R-2, $140-145 \mathrm{~cm}$, at $186.10 \mathrm{mbsf}$ (Fig. 9) shows that this would imply a load increase in the order of $15,000 \mathrm{kPa}$ for the type of sediment represented in this sample. For most of the oedometertested samples, void ratio reductions of this magnitude are not achieved at all during an entire test, with loading from near 0 to more than $24,000 \mathrm{kPa}$. From the discussion by Solheim et al. (chapter 9, this volume), load variations of this magnitude are impossible unless they represent nearly $1 \mathrm{~km}$ of deposition and erosion. High sediment loads, subsequently removed by erosion, would also have affected the geotechnical properties of the remainder of the cored sequence and not allowed deeper downhole fluctuations.

In addition to lithology, several of the geotechnical properties are dependent on the mineralogy of the fine fractions. In particular, this is the case for the activity, plasticity, permeability, and consolidation characteristics. A main factor is the ability of the different minerals to adsorb water (i.e., the activity of each mineral present in the sediment). High amounts of nonclay minerals (rock flour) in the clay fraction are typical for glacial sediments (Boulton and Paul, 1976; Solheim, in press). Although no quantification of the content of rock flour in the Prydz Bay sediments has been made, X-ray-diffraction studies indicate that it is significant, at least exceeding $20 \%$ (W. Ehrmann, pers. comm., 1989). In addition, the main clay minerals present are kaolinite and illite, both of which have low activities (Janbu, 1970). The sum of these factors results in an inactive sediment of relatively low plasticity which has low values of initial void ratios (before any load is applied). There is no significant decrease in permeability with increasing clay fraction and the material deforms relatively slowly even as a response to loads of up to $24000 \mathrm{kPa}$.

\section{SUMMARY AND CONCLUSIONS}

Below a thin veneer of normally consolidated sediments, which increases in thickness beyond the shelf edge, thick sequences of overconsolidated, high-strength diamictites are found on the continental shelf in Prydz Bay. Based on both shipboard and land-based geotechnical analyses, the glacigenic diamictons and diamictites show the following characteristics:

1. The lithology is relatively uniform. The main variations are found downhole and define the lithostratigraphic units described by Hambrey et al. (this volume). Stratified diamictites have higher proportions of silt and clay than the massive diamictites.

2. The overconsolidation, which is caused by glacial loading combined with great sediment loads removed by glacial erosion (Solheim et al., chapter 9, this volume), is illustrated in profiles of physical properties that show no trends indicative of increasing present overburden. Such a "normal" trend is, however, found for the normally consolidated diamictons of Site 743 , on the upper continental slope.

3. A number of fluctuations in physical properties are superimposed on the general, overconsolidated trend. These are caused by variations in the proportions of clay and silt relative to sand and gravel. The grain-size changes are caused by variations in the position of the grounding line of the ice sheet.

4 . The diamictites have average water contents, porosities, wet-bulk densities, and $P$-wave velocities in the order of $15 \%$, $30 \%, 2.3 \mathrm{~g} / \mathrm{cm}^{3}$, and $2200 \mathrm{~m} / \mathrm{s}$, respectively, but significant variation around these values is found, particularly at intermediate levels at Sites 739 and 742 .

5 . Because of a relatively high proportion of nonclay minerals and low-activity clay minerals (illite and kaolinite) in the clay fraction, the cored sediments generally are classified as inactive, of low to medium plasticity, and consolidate with little deformation even when subjected to great stresses. Deviations from this are found in two more mud-rich samples.

6. Permeabilities are low, and the bulk of the cored sediments are classified as practically impermeable. 


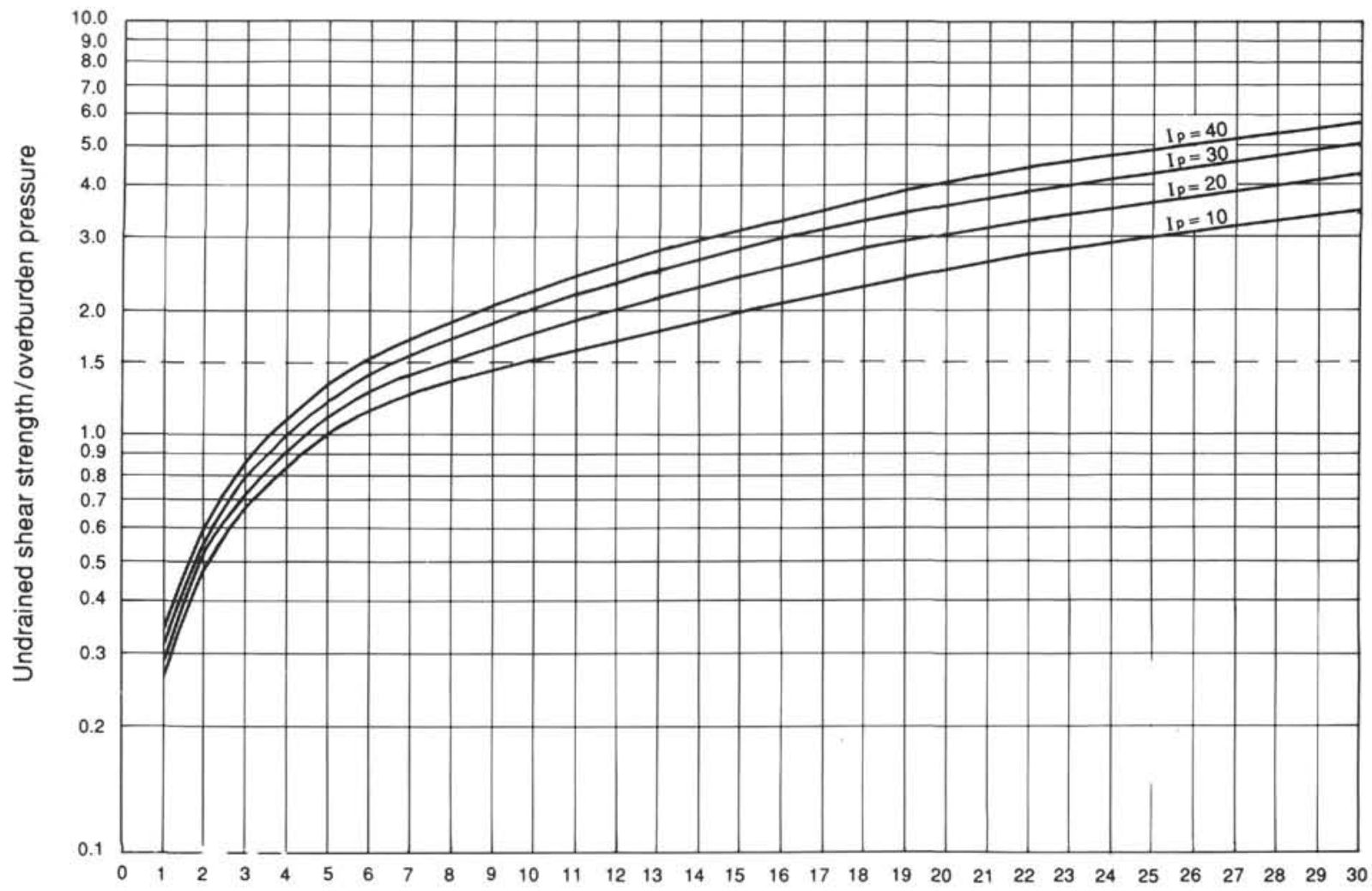

Preconsolidation pressure

Overburden pressure

Figure 12. Relationships between undrained shear strength, effective in-situ stress, overconsolidation ratio, and plasticity index $\left(I_{p}\right)$, based on correlations for Drammen clay and relationships obtained by Brooker and Ireland (1965) (from Andresen et al., 1979).

7. Undrained shear strengths of up to nearly $2500 \mathrm{kPa}$ were measured in triaxial tests. Because negative pore pressures develop during testing of this high-strength material, failure is not necessarily achieved during the shearing. Stress paths are used to show that there are at least two sediment types present, and that geotechnically, they behave somewhat differently.

8. Preconsolidation stresses up to $10,000 \mathrm{kPa}$ were measured in the oedometer tests. $P_{c}{ }^{\prime}$ values estimated empirically from undrained shear strength and plasticity, indicate that the oedometer results may underestimate, and therefore provide a conservative estimate of, past loads.

9. The present results compare well with results obtained from glacigenic deposits of other areas, including the Antarctic. This is, however, the first time Antarctic material from depths below seafloor exceeding those reachable by traditional piston, vibro, and gravity corers has been tested geotechnically. Based on seismic character from other areas around Antarctica (e.g., Elverhøi and Maisey, 1983; Cooper et al., 1987) and also on cores from boreholes (although without geotechnical analyses) (Barrett, 1989), sediments with a geotechnical character similar to that described in this paper can also be expected to exist in other parts of the Antarctic continental shelf that have a similar glacial erosion history.

\section{ACKNOWLEDGMENTS}

This study was funded by the Norwegian Research Council for Science and the Humanities (NAVF), under grant nos. D.48.40.072 and 443.89/023. The Norwegian Geotechnical Institute provided laboratory facilities and technical expertise at favorable prices. Astrid Stadheim, Mona Nyland Berg, Sten Boye Flood, and Bengt B. Larsen are acknowledged for preparation and analysis assistance. This is the Norwegian Polar Research Institute Contribution no. 269.

\section{REFERENCES}

Amundsen, T., Lunne, T., Christophersen, H. P., Bayne, J. M., and Barnwell, C. L., 1987. Advanced deep-water soil investigation at the Troll East Field. Norw. Geotech. Inst. Publ., 167:1-22.

Anderson, J. B., Brake, C. F., and Myers, N. C., 1984. Sedimentation on the Ross Sea continental shelf, Antarctica. Mar. Geol., 57:295333.

Anderson, J. B., Clark, H. C., and Weaver, F. M., 1977. Sediment and sediment processes on high latitude continental shelves. Proc. 9th Annu. Offshore Technology Conf., Houston, TX, Paper 2738, 9196.

Anderson, J. B., Kurtz, D. D., Domack, E. W., and Balshaw, K. M., 1980. Glacial and glacial marine sediments of the Antarctic continental shelf. J. Geol., 88:399-414.

Andresen, A., Berre, T., Kleven, A., and Lunne, T., 1979. Procedures used to obtain soil parameters for foundation engineering in the North Sea. Norw. Geotech. Inst. Publ., 129:1-18.

Atkinson, J. H., and Bransby, P. L., 1978. The Mechanics of Soils: An Introduction to Critical State Soil Mechanics: London (McGrawHill).

Barrett, P. J. (Ed.), 1989. Antarctic Cenozoic history from the CIROS-1 drillhole, McMurdo Sound. DSIR Bull., 245.

Barron, J., Larsen, B., et al., 1989. Proc. ODP, Init. Repts., 119: College Station, TX (Ocean Drilling Program).

Bennett, R. H., and Nelsen, T. A., 1983. Seafloor characteristics and dynamics affecting geotechnical properties at shelfbreaks. In Stanley, D. J., and Moore, G. T. (Eds.), The Shelf Break: Critical Inter- 
face on Continental Margins. Spec. Publ. Soc. Econ. Paleontol. Mineral., 33:333-355.

Berre, T., 1981. Triaxial testing at the Norwegian Geotechnical Institute. Norw. Geotech. Inst. Publ., 134:1-17.

Bjerrum, L., and Huder, J., 1957. Measurement of the permeability of compacted clays. Proc. 4th Inter. Conf. on Soil Mechanics, London, $1: 6-8$.

Boulton, G. S., and Paul, M. A., 1976. The influence of genetic properties on some geotechnical properties of glacial tills. Q. J. Eng. Geol., 9:159-194.

Brooker, E. W., and Ireland, H. O., 1965. Earth pressures at rest related to stress history. Can. Geotech. J., 2:1-15.

Bryant, W. B., Bennett, R. H., and Katherman, C. E., 1981. Shear strength, consolidation, porosity, and permeability of oceanic sediments. In Emiliani, C. (Ed.), The Sea (Vol. 7): New York (Wiley), $1555-1616$.

Casagrande, A., 1948. Classification and identification of soils. Trans. Am. Assoc. Civ. Eng., 113:901-930.

Chilingarian, G. V., and Wolf, K. H., 1975. Compaction of CoarseGrained Sediments: New York (Elsevier).

Cooper, A. K., Davey, F. J., and Behrendt, J. C., 1987. Seismic stratigraphy and structure of the Victoria Land Basin, Western Ross Sea, Antarctica. In Cooper, A. K., and Davey, F. J. (Eds.), The Antarctic Continental Margin: Geology and Geophysics of the Western Ross Sea: Houston, TX (Circum-Pacific Council for Energy and Mineral Resources), 5B:191-216.

Edwards, B. D., Lee, H. J., Karl, H. A., Reimnitz, E., and Timothy, L. A., 1987. Geology and physical properties of Ross Sea, Antarctica, continental shelf sediment. In Cooper, A. K., and Davey, F. J. (Eds.), The Antarctic Continental Margin: Geology and Geophysics of the Western Ross sea, Houston, TX (Circum-Pacific Council for Energy and Mineral Resources), 5B:191-216.

Eide, O., and Andersen, K. H., 1984. Foundation engineering of gravity structures in the Northern North Sea. Norw. Geotech. Inst. Publ., 154:1-48.

Elverhøi, A., and Maisey, G., 1983. Glacial erosion and morphology of the eastern and southeastern Weddell Sea shelf. In Oliver, R. L., James, P. R., and Jago, J. B. (Eds.), Antarctic Earth Science: Proc. 4th Inter. Symp. Antarctic Earth Sci., Adelaide, Australia, 1982, 483-487.

Elverhøi, A., and Roaldset, E., 1983. Glaciomarine sediments and suspended particulate matter, Weddell Sea Shelf, Antarctica. Polar Res., 1:1-21.

Hambrey, M. J., Larsen, B., Ehrmann, W. U., and ODP Leg 119 Shipboard Scientific Party, 1989. Forty million years of Antarctic glacial history yielded by Leg 119 of the Ocean Drilling Program. Polar Rec., 25:99-106.

Janbu, N., 1970. Grunnlag $i$ Geoteknikk: Trondheim, Norway (Tapir Forlag).

Jones, M. E., and Addis, M. A., 1985. On changes in porosity and volume during burial of argillaceous sediments. Mar. Pet. Geol., 2:47253.

Kazi, A., and Knill, J. L., 1969. The sedimentation and geotechnical properties of the Cromer Till, between Happisburgh and Cromer, Norfolk. Q. J. Eng. Geol., 2:63-86.

Kurtz, D. D., Anderson, J. B., Balshaw, K. M., and Cole, M. L., 1979. Glacial marine sedimentation: relationship to the distribution of sediment geotechnical properties on high latitude continental mar- gins. Proc. 11th Annu. Offshore Technol. Conf., Houston, TX, 1: 683-688.

Lacasse, S., 1988. Design parameters of clays from in-situ and laboratory tests. Int. Rep. 52155-50, Norw. Geotech. Inst.

Lambe, T. W., and Whitman, R. V., 1979. Soil Mechanics, SI Version: New York (Wiley).

Lien, R., Solheim, A., Elverhøi, A., and Rokoengen, K., 1989. Iceberg scouring and sea bed morphology on the eastern Weddell Sea shelf, Antarctica. Polar Res., 7:43-57.

Løken, T., Otter, R., and Forsberg, C. F., 1986. Kornfordelingsanalyser ved NGI. En vurdering av Sedigraph 5000 ET. Int. Rep. 51000-7, Norw. Geotech. Inst.

Lunne, T., Christoffersen, H. P., and Tjelta, T. I., 1986. Engineering use of piezocone data in North Sea clays. Norw. Geotech. Inst. Publ., 163:1-7.

Lunne, T., Tjelta, T. I., and Lacasse, S., 1983. Soil investigation for a North Sea gravity platform. Norw. Geotech. Inst. Publ., 146:1-9.

Norwegian Standard, 1982a. Konusflytegrensen (the fall cone liquid limit). Norges Byggstandardiseringsrad, NS 8002.

1982b. Plastisitetsgrensen (the plastic limit). Norges Byggstandardiseringsrad, NS 8003.

Sandbaekken, G., Berre, T., and Lacasse, S., 1986. Oedometer testing at the Norwegian Geotechnical Institute. In Yong, R. N., and Townsend, F. C. (Eds.), Consolidation of Soils: Testing and Evaluation: Philadelphia (ASTM) STP 892, 329-353.

Shipboard Scientific Party, 1989a. Explanatory Notes. In Barron, J., Larsen, B., et al., Proc. ODP, Init. Repts., 119: College Station, TX (Ocean Drilling Program), 15-44.

1989b. Site 739. In Barron, J., Larsen, B., et al., Proc. ODP, Init. Repts., 119: College Station, TX (Ocean Drilling Program), 289-344.

1989c. Site 742. In Barron, J., Larsen, B., et al., Proc. ODP Init. Repts., 119: College Station, TX (Ocean Drilling Program), 397-458.

1989d. Site 743. In Barron, J., Larsen, B., et al., Proc. ODP, Init. Repts., 119: College Station, TX (Ocean Drilling Program), 459-476.

Skempton, A. W., 1953. Soil mechanics in relation to geology. Proc. Yorkshire Geol. Soc., 29:33-62.

Solheim, A., in press. The depositional environment of surging sub- polar tidewater glaciers: a case study of the morphology, sedimentation and sediment properties in a surge-affected marine basin outside Nordaustlandet, northern Barents Sea. Skr.- Nor. Polarinst.

Solheim, A., Milliman, J. D., and Elverhøi, A., 1988. Sediment distribution and sea floor morphology of Storbanken: implications for the glacial history of the northern Barents Sea. Can. J. Earth Sci., 25:547-556.

Stagg, H.M.J., 1985. The structure and origin of Prydz Bay and MacRobertson Shelf, East Antarctica. Tectonophysics, 114:315-340.

Terzaghi, K., and Peck, R. B., 1967. Soil Mechanics in Engineering Practice (2nd ed.): New York (Wiley).

Wagner, A. A., 1957. The use of the unified soil classification system by the Bureau of Reclamation. Proc. 4th Inter. Conf. on Soil Mechanics and Foundation Engineering, London, 1:125-134.

Date of initial receipt: 18 December 1989

Date of acceptance: 20 July 1990

Ms 119B-186 
APPENDIX

Results of All Shipboard Analyses of Physical Properties from the Prydz Bay Sites

\begin{tabular}{|c|c|c|c|c|c|c|c|c|c|c|c|c|c|c|}
\hline \multirow{2}{*}{$\begin{array}{l}\text { Depth } \\
\text { (mbsf) }\end{array}$} & \multirow{2}{*}{$\begin{array}{l}\text { Water } \\
\text { content } \\
(\%)\end{array}$} & \multirow{2}{*}{$\begin{array}{l}\text { Porosity } \\
\text { (\%) }\end{array}$} & \multirow{2}{*}{$\begin{array}{l}\text { Wet-bulk } \\
\text { density } \\
\left(\mathrm{g} / \mathrm{cm}^{3}\right)\end{array}$} & \multirow{2}{*}{$\begin{array}{l}\text { Dry-bulk } \\
\text { density } \\
\left(\mathrm{g} / \mathrm{cm}^{3}\right)\end{array}$} & Grain & GRAPE $^{a}$ & $\underset{\text { she: }}{U}$ & $\begin{array}{l}\text { drained } \\
\text { strength }\end{array}$ & & & & & & \\
\hline & & & & & $\left(\mathrm{g} / \mathrm{cm}^{3}\right)$ & $\left(\mathrm{g} / \mathrm{cm}^{3}\right)$ & $(\mathrm{kPa})$ & Instrument $^{\mathrm{b}}$ & $(\mathrm{m} / \mathrm{s})$ & $\begin{array}{l}\mathrm{VpA} \mathrm{A}^{\mathrm{a}} \\
(\mathrm{m} / \mathrm{s})\end{array}$ & $\begin{array}{l}\text { Gravel } \\
(\%)\end{array}$ & $\begin{array}{l}\text { Sand } \\
(\%)\end{array}$ & $\begin{array}{l}\text { Silt } \\
(\%)\end{array}$ & $\begin{array}{l}\text { Clay } \\
(\%)\end{array}$ \\
\hline Site 739 & & & & & & & & & & & & & & \\
\hline 0.6 & 18.5 & 37.28 & 2.17 & 1.77 & 2.66 & & 23 & w & 1782.6 & & 2.09 & 47.92 & 17.55 & 27.44 \\
\hline 1.92 & 19.7 & 40.93 & 2.2 & 1.77 & 2.87 & & 5 & w & 1912.4 & & & & & \\
\hline 3.32 & 20.57 & 41.6 & 2.18 & 1.73 & 2.79 & & 15 & w & 2066.1 & & 2.13 & 42.24 & 21.7 & 33.93 \\
\hline 5 & 19.67 & 40.49 & 2.24 & 1.8 & 2.82 & & 63 & w & 2263.2 & & & & & \\
\hline 1 & 22.83 & 43.96 & 2.1 & 1.62 & 2.69 & & & & & & & & & \\
\hline 24.3 & & & & & & & 890 & P & & & & & & \\
\hline 24.9 & 14.68 & 31.56 & 2.22 & 1.9 & 2.72 & & 930 & $\mathrm{P}$ & & & & & & \\
\hline 25.3 & & & & & & 2.29 & 870 & $\mathrm{P}$ & & & 1.72 & 45.68 & 11.57 & 41.03 \\
\hline $\begin{array}{l}26 \\
26,3\end{array}$ & 11.88 & 26.63 & 2.37 & 2.08 & 2.74 & 2.34 & 925 & $P$ & 2106 & & & & & \\
\hline $\begin{array}{l}26.3 \\
26.7\end{array}$ & & & & & & & $\begin{array}{l}930 \\
795\end{array}$ & $\begin{array}{l}\mathrm{P} \\
\mathrm{P}\end{array}$ & & & & & & \\
\hline $\begin{array}{l}26.7 \\
27.6\end{array}$ & 16.88 & 35.2 & 2.41 & 2.01 & 2.72 & 2.3 & $\begin{array}{l}795 \\
915\end{array}$ & $\begin{array}{l}\mathrm{P} \\
\mathrm{P}\end{array}$ & 2140.6 & & 2.36 & 43.57 & 14.6 & 39.47 \\
\hline 28.8 & 16.5 & 33.76 & 2.28 & 1.9 & 2.62 & 2.32 & & & 2106.7 & & & & & \\
\hline 29 & 14.85 & 32.74 & 2.38 & 2.03 & 2.84 & 2.37 & & & 2099 & & 7.5 & 43.64 & 21.99 & 26.87 \\
\hline 29.58 & 13.69 & 30.09 & 2.44 & 2.11 & 2.76 & & & & & & 1.31 & 48.75 & 12.98 & 36.96 \\
\hline 30.44 & 15.54 & 31.9 & 2.24 & 1.89 & 2.59 & 2.31 & 863 & P & 2113 & & 3.76 & 43.54 & 16.34 & 36.36 \\
\hline 31.24 & 12.4 & 26.79 & 2.48 & 2.17 & 2.63 & & 945 & $\mathrm{P}$ & & & & & & \\
\hline 31.8 & 13.35 & 28.63 & 2.27 & 1.97 & 2.64 & 2.31 & 916 & P & 2229 & & 4.68 & 44.76 & 15.67 & 34.88 \\
\hline 57.62 & 14.02 & 31.48 & 2.41 & 2.07 & 2.86 & & & & & & & & & \\
\hline 67.38 & 12.44 & 27.21 & 2.29 & 2.01 & 2.67 & 2.26 & 480 & P & 2411 & & & & & \\
\hline 106.37 & 11.32 & 25.77 & 2.38 & 2.11 & 2.76 & 2.24 & 760 & P & 2173 & & 2.58 & 50.01 & 21.81 & 25.6 \\
\hline 106.77 & 10.33 & 23.03 & 2.37 & 2.12 & 2.64 & 2431 & & & & & & & & \\
\hline 107.21 & 9.59 & 22.03 & 2.39 & 2.17 & 2.71 & 2.33 & & & 2208 & & 0.84 & 49.79 & 18.32 & 31.10 \\
\hline 107.53 & 10.49 & 23.74 & 2.36 & 2.11 & 2.7 & 2.35 & 935 & P & 2234 & & & & & \\
\hline 115.7 & 11.48 & 24.64 & 2.26 & 2 & 2.56 & 2.29 & 940 & P & 2365.4 & & 1.12 & 47.96 & 19.35 & 31.57 \\
\hline 116.89 & 7.1 & 16.74 & 2.47 & 2.29 & 2.67 & 2.44 & & & 2760 & & & & & \\
\hline 117.09 & 10.99 & 24.28 & 2.3 & 2.04 & 2.64 & 2.31 & & & 2215.4 & & 0.75 & 47.8 & 19.55 & 31.9 \\
\hline 117.91 & 7.08 & 16.77 & 2.49 & 2.32 & 2.69 & 2.39 & & & 2561.4 & & & & & \\
\hline 118.58 & 6.43 & 15.08 & 2.45 & 2.29 & 2.63 & 2.42 & & & 2487 & & 1.39 & 52.32 & 20.37 & 25.92 \\
\hline 119.31 & & & & & & 2.41 & & & 2482.4 & & & & & \\
\hline 119.46 & 8.52 & 20.37 & 2.51 & 2.29 & 2.79 & & & & & & & & & \\
\hline 125.5 & 11.42 & 25.59 & 2.48 & 2.2 & 2.71 & 2.35 & & & 2274 & & 0.7 & 48.68 & 15.69 & 34.93 \\
\hline 126.38 & 9.47 & 21.31 & 2.45 & 2.22 & 2.63 & & & & & & 0.9 & 44.53 & 15.28 & 39.29 \\
\hline 130.4 & 15.14 & 31.21 & 2.47 & 2.1 & 2.58 & 2.34 & 930 & $P$ & 2232 & & & & & \\
\hline 131.65 & 12.57 & 26.99 & 2.3 & 2.01 & 2.61 & & & & & & 2.28 & 47.57 & 14.54 & 35.61 \\
\hline 131.95 & 13.06 & 26.78 & 2.26 & 1.96 & 2.47 & 2.35 & & & 2324.5 & & & & & \\
\hline 132.88 & 11.5 & 25.52 & 2.36 & 2.09 & 2.68 & & & & & & & & & \\
\hline 133.56 & 17.37 & 36.18 & 2.21 & 1.82 & 2.74 & 2.36 & & & 2351.8 & & 9.91 & 44.93 & 14.45 & 30.7 \\
\hline 134.51 & 11.62 & 25.41 & 2.38 & 2.11 & 2.63 & & & & & & & & & \\
\hline 135.65 & & & & & & 2.21 & & & 2235.3 & & & & & \\
\hline 136.16 & 12.08 & 26.66 & 2.42 & 2.13 & 2.69 & & & & & & & & & \\
\hline 136.83 & 14.34 & 31.22 & 2.66 & 2.28 & 2.76 & & & & & & & & & \\
\hline 137.67 & 12.15 & 26.7 & 2.32 & 2.04 & 2.68 & 2.35 & & & & & & & & \\
\hline 139.07 & 10.83 & 23.88 & 2.34 & 2.09 & 2.62 & 2.24 & & & 2506.4 & & 3.97 & 46.11 & 20.47 & 29.45 \\
\hline 140 & 9.94 & 21.87 & 2.34 & 2.11 & 2.58 & & & & 2466.7 & & & & & \\
\hline 140.23 & 23.91 & 44.16 & 2.04 & 1.55 & 2.55 & 2.3 & & & & & & & & \\
\hline 140.55 & 18.03 & 36.81 & 2.25 & 1.84 & 2.69 & 2.2 & & & 2132 & & & & & \\
\hline 141.65 & 16.33 & 33.72 & 2.16 & 1.81 & 2.65 & 2.35 & & & 2500 & & 2.04 & 45.45 & 24.68 & 27.83 \\
\hline 142.38 & 21.86 & 42.73 & 2.22 & 1.74 & 2.71 & & & & & & & & & \\
\hline 143.4 & & & & & & & & & 2075.3 & & & & & \\
\hline 144.86 & 11.58 & 25.24 & 2.35 & 2.08 & 2.62 & 2.29 & & & 2287.6 & & & & & \\
\hline 145.7 & 14.23 & 30.72 & 2.5 & 2.14 & 2.72 & & & & & & 2.44 & 47.35 & 19.58 & 30.63 \\
\hline 146.33 & 17.61 & 35.03 & 2.06 & 1.7 & 2.56 & 2.4 & & & 2584 & & & & & \\
\hline 147.14 & 13.3 & 29 & 2.41 & 2.09 & 2.72 & & & & & & & & & \\
\hline 147.8 & 13.94 & 29.31 & 2.34 & 2.01 & 2.6 & 2.11 & & & 2306.2 & & & & & \\
\hline 148.3 & 12.95 & 26.4 & 2.27 & 1.98 & 2.45 & & & & & & & & & \\
\hline 150.19 & 11.99 & 26.44 & 2.33 & 2.05 & 2.68 & 2.31 & & & 2281.5 & & 1.43 & 48.91 & 19.86 & 29.8 \\
\hline 150.84 & 14 & 29.94 & 2.48 & 2.13 & 2.67 & & & & & & 6.84 & 67.22 & 9.08 & 16.86 \\
\hline 151.4 & 12.58 & 26.65 & 2.33 & 2.04 & 2.56 & 2.27 & & & 2361.7 & & & & & \\
\hline 152.2 & 10.94 & 24.54 & 2.39 & 2.13 & 2.69 & & & & & & & & & \\
\hline 152.71 & 12.8 & 27.57 & 2.41 & 2.1 & 2.64 & 2.07 & & & 2297.9 & & 8.16 & 45.35 & 21.38 & 25.11 \\
\hline 154.77 & 14.54 & 31.71 & 2.58 & 2.2 & 2.77 & 2.31 & & & 2467 & & & & & \\
\hline 155.48 & 12.74 & 27.32 & 2.33 & 2.04 & 2.62 & & & & & & 2 & 39.78 & 29.11 & 29.11 \\
\hline 156.08 & 13.17 & 27.79 & 2.25 & 1.96 & 2.58 & 2.27 & & & 2181.1 & & & & & \\
\hline 157.2 & 11.79 & 25.39 & 2.36 & 2.08 & 2.59 & & & & & & 3.95 & 47.24 & 19.52 & 29.29 \\
\hline 157.98 & 12.54 & 27.49 & 2.45 & 2.14 & 2.69 & 2.22 & & & 2336.1 & & & & & \\
\hline 158.47 & & & & & & & & & & & 1.24 & 41.6 & 18.29 & 38.87 \\
\hline 159.54 & 11.92 & 26.06 & 2.33 & 2.05 & 2.65 & 2.32 & & & 2291.7 & & & & & \\
\hline 160.07 & 11.31 & 24.97 & 2.43 & 2.16 & 2.65 & & & & & & 13.98 & 38.12 & 15.33 & 32.5 \\
\hline 160.95 & 11.45 & 25.16 & 2.33 & 2.06 & 2.64 & 2.26 & & & 2335.1 & & & & & \\
\hline 161.45 & 9.23 & 20.95 & 2.42 & 2.2 & 2.65 & & & & 2693.2 & & 3.05 & 44.82 & 28.15 & 23.98 \\
\hline
\end{tabular}


Appendix (continued).

\begin{tabular}{|c|c|c|c|c|c|c|c|c|c|c|c|c|c|c|}
\hline \multirow{2}{*}{$\begin{array}{l}\text { Depth } \\
\text { (mbsf) }\end{array}$} & \multirow{2}{*}{$\begin{array}{c}\text { Water } \\
\text { content } \\
(\%)\end{array}$} & \multirow{2}{*}{$\begin{array}{c}\text { Porosity } \\
(\%)\end{array}$} & \multirow{2}{*}{$\begin{array}{l}\text { Wet-bulk } \\
\text { density } \\
\left(\mathrm{g} / \mathrm{cm}^{3}\right)\end{array}$} & \multirow{2}{*}{$\begin{array}{c}\text { Dry-bulk } \\
\text { density } \\
\left(\mathrm{g} / \mathrm{cm}^{3}\right)\end{array}$} & $\begin{array}{c}\text { Grain } \\
\text { density }\end{array}$ & $\begin{array}{l}\text { GRAPE }^{a} \\
\text { density }\end{array}$ & & $\begin{array}{l}\text { drained } \\
\text { strength }\end{array}$ & $V p A^{c}$ & $\mathrm{VpA}^{\mathrm{d}}$ & & & & \\
\hline & & & & & & & $(\mathrm{kPa})$ & Instrument ${ }^{\mathrm{b}}$ & $(\mathrm{m} / \mathrm{s})$ & $(\mathrm{m} / \mathrm{s})$ & $(\%)$ & $(\%)$ & $(\%)$ & $(\%)$ \\
\hline Site 739 & & & & & & & & & & & & & & \\
\hline 163.57 & 8.64 & 19.89 & 2.47 & 2.25 & 2.67 & 2.35 & & & 2428.6 & & & & & \\
\hline 164.41 & 8.96 & 20.09 & 2.39 & 2.18 & 2.6 & 2.14 & & & 2830 & & 3.42 & 44.18 & 22.53 & 29.87 \\
\hline 165.31 & 9.51 & 21.48 & 2.46 & 2.23 & 2.64 & 2.35 & & & 2490 & & & & & \\
\hline 165.87 & 9.28 & 21.19 & 2.5 & 2.27 & 2.67 & 2.29 & & & 2414.8 & & 6.53 & 43.39 & 16.03 & 34.05 \\
\hline 166.67 & 9.97 & 22.36 & 2.4 & 2.16 & 2.64 & 2.32 & & & 2389.3 & & 2.36 & 45.95 & 17.06 & 34.63 \\
\hline 167.03 & 9.8 & 22.91 & 2.54 & 2.29 & 2.78 & 2.34 & & & 2281.4 & & 2.29 & 48.61 & 14.73 & 34.37 \\
\hline 173.88 & 14.29 & 30.94 & 2.35 & 2.02 & 2.73 & & & & 2536.9 & & & & & \\
\hline 174.59 & 14.89 & 31.37 & 2.24 & 1.91 & 2.65 & & & & 2422.7 & & & & & \\
\hline 183.39 & 15.19 & 32.22 & 2.3 & 1.95 & 2.69 & 2.09 & & & 2224.9 & & 2.49 & 41.01 & 30.51 & 25.99 \\
\hline 184.28 & 17.92 & 36.32 & 2.21 & 1.81 & 2.65 & 2.11 & & & 2273.5 & & 0.47 & 29.53 & 39.2 & 30.8 \\
\hline 184.8 & 19.78 & 37.99 & 2.02 & 1.62 & 2.52 & 2.05 & & & 2077.6 & & 0.35 & 16.59 & 49.84 & 33.22 \\
\hline 185.83 & 16.97 & 35.68 & 2.21 & 1.84 & 2.76 & 2.09 & & & 2301.5 & & 0.57 & 30.8 & 21.49 & 30.2 \\
\hline 186.66 & 19.69 & 40.02 & 2.23 & 1.79 & 2.76 & 2.11 & & & 2176.6 & & 0.36 & 29.5 & 33.67 & 36.47 \\
\hline 187.33 & 20.47 & 39.9 & 2.09 & 1.66 & 2.62 & & & & & & 0.19 & 20 & 38.3 & 41.5 \\
\hline 187.54 & & & & & & 2.03 & & & 2097.3 & & & & & \\
\hline 187.97 & 19.26 & 38.47 & 2.12 & 1.71 & 2.66 & 2.05 & & & 2127.8 & & & & & \\
\hline $\begin{array}{r}193.07 \\
40.61\end{array}$ & 21.79 & 42.51 & 2.09 & 1.64 & & & & & & & 2.69 & 2.8 & 15.99 & 40.61 \\
\hline 193.6 & 20.78 & 41.91 & 2.15 & 1.71 & 2.79 & & & & & & 6.24 & 21.17 & 26.13 & 46.45 \\
\hline 202.8 & 15.45 & 31.64 & 2.21 & 1.87 & 2.57 & 2.19 & & & 2392.5 & & 4.94 & 39.17 & 27.94 & 27.94 \\
\hline 203.58 & 11.44 & 25.42 & 2.38 & 2.1 & 2.68 & 2.32 & & & 2637.3 & & 0.63 & 69.52 & 14.92 & 14.93 \\
\hline 204.5 & 15.48 & 32.41 & 2.24 & 1.89 & 2.66 & 2.15 & & & 2373.2 & & 2.66 & 36.01 & 33.12 & 28.21 \\
\hline 205.35 & 11.36 & 25.73 & 2.39 & 2.12 & 2.75 & 2.29 & & & 2739.4 & & 6.08 & 58.18 & 19.66 & 16.08 \\
\hline 206.29 & 12.75 & 28.46 & 2.48 & 2.17 & 2.77 & 2.25 & & & 2664.7 & & 0.94 & 49.77 & 29.57 & 19.72 \\
\hline 207.27 & 13.15 & 29.11 & 2.38 & 2.07 & 2.76 & 2.07 & & & 2460 & & 1.43 & 44.47 & 26.51 & 27.59 \\
\hline 208.28 & 12.25 & 26.76 & 2.35 & 2.06 & 2.66 & 2.21 & & & 2674.6 & & & & & \\
\hline 212.53 & 11.97 & 26.05 & 2.34 & 2.06 & 2.63 & 2.21 & & & 2444.4 & & 2.64 & 59.34 & 20.15 & 17.87 \\
\hline 213.23 & 12.14 & 26.9 & 2.35 & 2.06 & 2.7 & 2.23 & & & 2472 & & 3.22 & 47.88 & 24.94 & 23.96 \\
\hline 214.03 & 15.11 & 32.77 & 2.33 & 1.98 & 2.78 & 2.19 & & & 2303.1 & & 1.04 & 44.26 & 30.08 & 24.61 \\
\hline 215.61 & 16 & 33.69 & 2.18 & 1.83 & 2.71 & 2.14 & & & 2281.3 & & 2 & 34.12 & 24.91 & 38.97 \\
\hline 217.25 & 16.84 & 35.79 & 2.29 & 1.91 & 2.8 & 2.16 & & & 2178.8 & & 1.04 & 31.76 & 35.62 & 31.58 \\
\hline 218.02 & 19.69 & 38.82 & 2.11 & 1.69 & 2.63 & 2.1 & & & 2026.8 & & 0.72 & 25.59 & 29.48 & 44.21 \\
\hline 219.04 & 12.12 & 26.98 & 2.35 & 2.07 & 2.72 & 2.23 & & & 2559.8 & & 18.31 & 46.55 & 17.22 & 17.92 \\
\hline 222.1 & 21.2 & 43.4 & 2.33 & 1.84 & 2.89 & 2.06 & & & 2120.8 & & & & & \\
\hline 223.19 & 21.2 & 39.4 & 2.07 & 1.63 & 2.66 & & & & & & & & & \\
\hline 223.51 & 19.41 & 39.37 & 2.21 & 1.78 & 2.74 & 1.92 & & & 2136.4 & & & & & \\
\hline 225.75 & & & & & & 2.04 & & & 2124 & & & & & \\
\hline 226.3 & 20.41 & 41.9 & 2.47 & 1.96 & 2.86 & & & & & & & & & \\
\hline 226.68 & 19.06 & 38.53 & 2.18 & 1.76 & 2.7 & 2.02 & & & 2290 & & & & & \\
\hline 227.39 & 22.17 & 38.31 & 2.05 & 1.6 & 2.21 & & & & & & & & & \\
\hline 227.93 & 21.07 & 39.03 & 2.11 & 1.67 & 2.43 & 2.05 & & & & & 1.87 & 33.04 & 32.55 & 32.54 \\
\hline 228.38 & 19.69 & 39.35 & 2.21 & 1.78 & 2.69 & & & & & & & & & \\
\hline 229.03 & & & & & & & & & 2362.3 & & & & & \\
\hline 229.78 & 18.78 & 37.67 & 2.14 & 1.74 & 2.65 & 2.13 & & & 1926.3 & & & & & \\
\hline 232.08 & 19.58 & 38.89 & 2.2 & 1.77 & 2.65 & 2.04 & & & 2113.7 & & & & & \\
\hline 232.76 & 22.25 & 43.12 & 2.06 & 1.6 & 2.69 & & & & & & & & & \\
\hline 233.56 & 21.75 & 43.42 & 2.09 & 1.64 & 2.8 & 2.1 & & & 2193.4 & & 0.84 & 27.56 & 41.53 & 30.07 \\
\hline 234 & 22.1 & 42.74 & 2.09 & 1.62 & 2.67 & & & & & & 0.27 & 30.25 & 36.82 & 32.66 \\
\hline 234.65 & 19.06 & 38.1 & 2.17 & 1.76 & 2.65 & 2.14 & & & 2260.9 & & & & & \\
\hline 236.78 & 20.45 & 40.68 & 2.04 & 1.63 & 2.71 & 2.05 & & & 2205.9 & & & & & \\
\hline 237.35 & 20.46 & 40.75 & 2.09 & 1.67 & 2.72 & & & & & & 0.43 & 24.01 & 75.56 & \\
\hline 237.59 & 21.31 & 42.01 & 2.09 & 1.64 & 2.71 & 1.96 & & & 1923.1 & & & & & \\
\hline 241.28 & 18.14 & 37.15 & 2.17 & 1.77 & 2.71 & 2.06 & & & 2000 & & 0.31 & 48.38 & 23.09 & 28.22 \\
\hline 242.02 & 22.54 & 44.04 & 2.09 & 1.62 & 2.74 & & & & & & & & & \\
\hline 251.14 & 28.6 & 50.36 & 1.8 & 1.29 & 2.57 & 1.96 & & & 1962.4 & & & & & \\
\hline 252.14 & 23.18 & 45.48 & 2.2 & 1.69 & 2.81 & & & & & & & & & \\
\hline 252.39 & 26.72 & 47.23 & 1.93 & 1.41 & 2.49 & 1.87 & & & 1911.8 & & 0 & 17.64 & 49.42 & 32.94 \\
\hline 253.66 & 30.39 & 55.95 & 2.15 & 1.49 & 2.95 & & & & & & 0 & 20.78 & 79.22 & \\
\hline 254.1 & 32.87 & 57.5 & 1.82 & 1.22 & 2.8 & 1.81 & & & 2011.1 & & 0 & 9.89 & 57.67 & 32.44 \\
\hline 254.96 & 19.03 & 38.01 & 2.23 & 1.8 & 2.65 & & & & & & & & & \\
\hline 255.4 & & & & & & 1.85 & & & 1887 & & 0 & 20.95 & 37.15 & 41.9 \\
\hline 256.08 & 28.76 & 52.13 & 2.14 & 1.52 & 2.74 & & & & & & 0 & 18.23 & 37.61 & 44.16 \\
\hline 257.14 & 24.71 & 46.43 & 2.02 & 1.52 & 2.68 & 2.03 & & & 2124.1 & & 0 & 21.64 & 45.45 & 32.91 \\
\hline 258.88 & 20.18 & 39.89 & 2.18 & 1.74 & 2.67 & 2.03 & & & 2165.6 & & 0 & 29.15 & 31.88 & 38.97 \\
\hline 260.82 & 20.4 & 37.8 & 1.97 & 1.57 & 2.41 & 1.95 & & & 2085.7 & & & & & \\
\hline 261.7 & 16.1 & 35 & 2.19 & 1.84 & 2.85 & & & & & & 2.7 & 31.5 & 65.8 & \\
\hline 262.27 & 14.2 & 28.3 & 2.02 & 1.73 & 2.43 & 2.07 & & & 2196.9 & & & & & \\
\hline 262.7 & 17.1 & 32.9 & 1.98 & 1.64 & 2.41 & & & & & & & & & \\
\hline 263.5 & 24.94 & 48.04 & 2.13 & 1.6 & 2.82 & 1.82 & & & 1969.4 & & 0 & 11.24 & 48.82 & 39.94 \\
\hline 263.88 & 28.53 & 51.29 & 1.94 & 1.39 & 2.68 & & & & & & 0 & 8 & 49.68 & 42.32 \\
\hline 265.49 & 20.27 & 39.54 & 2.09 & 1.67 & 2.61 & 2.03 & & & 1915.3 & & & & & \\
\hline 266.2 & 20.11 & 39.75 & 2.11 & 1.68 & 2.66 & & & & & & 2.02 & 23.38 & 40.28 & 34.32 \\
\hline
\end{tabular}


Appendix (continued).

\begin{tabular}{|c|c|c|c|c|c|c|c|c|c|c|c|c|c|c|}
\hline \multirow{2}{*}{$\begin{array}{l}\text { Depth } \\
\text { (mbsf) }\end{array}$} & \multirow{2}{*}{$\begin{array}{c}\text { Water } \\
\text { content } \\
(\%)\end{array}$} & \multirow{2}{*}{$\begin{array}{l}\text { Porosity } \\
(\%)\end{array}$} & \multirow{2}{*}{$\begin{array}{l}\text { Wet-bulk } \\
\text { density } \\
\left(\mathrm{g} / \mathrm{cm}^{3}\right)\end{array}$} & Dry-bulk & $\begin{array}{l}\text { Grain } \\
\text { density }\end{array}$ & GRAPE $^{a}$ & & $\begin{array}{l}\text { drained } \\
\text { strength }\end{array}$ & $\mathrm{V}_{\mathrm{DA}} \mathrm{c}^{\mathrm{c}}$ & $\mathrm{y}_{\mathrm{n}} \mathrm{A}^{\mathrm{d}}$ & & & & \\
\hline & & & & & $\left(\mathrm{g} / \mathrm{cm}^{3}\right)$ & & $\overline{(\mathrm{kPa})}$ & Instrument ${ }^{b}$ & $(\mathrm{~m} / \mathrm{s})$ & $(\mathrm{m} / \mathrm{s})$ & $(\%)$ & $(\%)$ & $(\%)$ & $(\%)$ \\
\hline Site 739 & & & & & & & & & & & & & & \\
\hline 266.65 & 22.52 & 44.27 & 2.12 & 1.64 & 2.77 & 1.96 & & & 2214.3 & & 2.11 & 20.94 & 38.47 & 38.48 \\
\hline 270.32 & 29 & 53.04 & 1.96 & 1.39 & 2.81 & 1.92 & & & 1964.6 & & & & & \\
\hline 271.16 & 25.41 & 47.86 & 2.01 & 1.5 & 2.73 & & & & & & & & & \\
\hline 272 & 26.43 & 50.56 & 2.07 & 1.52 & 2.89 & 1.91 & & & 1988.2 & & & & & \\
\hline 272.72 & 16.13 & 33.96 & 2.2 & 1.85 & 2.72 & & & & & & & & & \\
\hline 273.01 & 12.89 & 23.92 & 2 & 1.74 & 2.16 & 1.94 & & & 2110.1 & & 0 & 14.83 & 40.03 & 45.14 \\
\hline 274.23 & 12.63 & 24.27 & 2.02 & 1.77 & 2.25 & & & & & & & & & \\
\hline 274.69 & 17.65 & 32.27 & 1.92 & 1.58 & 2.25 & 2.16 & & & 2233.9 & & 0.49 & 15.33 & 44.61 & 39.57 \\
\hline 280.78 & 23.31 & 44.91 & 2.05 & 1.57 & 2.72 & 1.59 & & & 2089.1 & & & & & \\
\hline 281.8 & 26.02 & 46.98 & 2.14 & 1.58 & 2.55 & 1.99 & & & 1843.4 & & & & & \\
\hline 282.67 & 21.87 & 42.23 & 1.99 & 1.56 & 2.65 & & & & & & 0.4 & 21.06 & 43.2 & 35.34 \\
\hline 282.9 & 24.6 & 46.31 & 2.08 & 1.57 & 2.68 & 2.25 & & & 2059 & & & & & \\
\hline 283.55 & 24.88 & 47.54 & 2.15 & 1.62 & 2.78 & & & & & & 1 & 22.47 & 38.26 & 38.27 \\
\hline 284.67 & 25.59 & 45.92 & 1.96 & 1.46 & 2.5 & 1.95 & & & 2114.5 & & & & & \\
\hline 285.6 & 23.38 & 45.5 & 2.27 & 1.74 & 2.78 & & & & & & 0 & 22.73 & 44.82 & 32.45 \\
\hline 286.24 & 23.77 & 43.21 & 2 & 1.52 & 2.47 & 1.9 & & & 1968.7 & & & & & \\
\hline 286.68 & 25.07 & 48.55 & 2.15 & 1.61 & 2.86 & & & & & & 1.5 & 21.36 & 41.66 & 35.48 \\
\hline 289.6 & 19.75 & 41.5 & 2.31 & 1.85 & 2.93 & 2.16 & & & 2309.2 & & & & & \\
\hline 298.98 & 21.42 & 42.23 & 2.3 & 1.81 & 2.72 & 2.13 & & & 2186.4 & & & & & \\
\hline 300.35 & 17.35 & 35.18 & 2.15 & 1.78 & 2.63 & & & & & & & & & \\
\hline 300.54 & 18.88 & 38.1 & 2.23 & 1.81 & 2.68 & 2.15 & & & 2197.5 & & & & & \\
\hline 301.36 & 16.31 & 34.19 & 2.27 & 1.9 & 2.71 & & & & & & 7.35 & 33.15 & 27.37 & 32.13 \\
\hline 301.95 & 17.2 & 36.18 & 2.23 & 1.85 & 2.77 & 2.15 & & & 2210.5 & & 5.22 & 33.81 & 33.53 & 27.44 \\
\hline 302.5 & & & & & & & & & & & 0 & 31.98 & 36.05 & 31.97 \\
\hline 303.6 & 17.99 & 37.67 & 2.21 & 1.82 & 2.8 & 2.06 & & & 2442.8 & & & & & \\
\hline 308.85 & & & & & & 2.07 & & & 1954.4 & & & & & \\
\hline 309.81 & 21.8 & 42.39 & 2.07 & 1.62 & 2.68 & & & & & & & & & \\
\hline 310.4 & & & & & & 2.26 & & & 2280.9 & & & & & \\
\hline 311.18 & 12.85 & 27.92 & 2.3 & 2 & 2.67 & & & & & & & & & \\
\hline 312.06 & 14.6 & 31.88 & 2.31 & 1.97 & 2.78 & 2.27 & & & $\begin{array}{l}2203.6 \\
2180.5\end{array}$ & & & & & \\
\hline 313.08 & 14.22 & 29.52 & 2.24 & 1.92 & 2.57 & 2.26 & & & 2180.5 & & & & & \\
\hline 318.7 & 11.8 & 24.6 & 2.23 & 1.97 & 2.49 & 2.26 & & & 2188.5 & & & & & \\
\hline 319.47 & 13.4 & 28 & 2.25 & 1.95 & 2.56 & 2.25 & & & 2125.6 & & 2.96 & 38.63 & 21.02 & 37.38 \\
\hline 328.04 & 13.6 & 29.7 & 2.3 & 1.98 & 2.71 & 2.15 & & & 2126.1 & & & & & \\
\hline 329.03 & 11.9 & 26.2 & 2.34 & 2.06 & 2.68 & 2.26 & & & 2222.2 & & 4.05 & 40.92 & 18.71 & 36.32 \\
\hline 329.9 & 12.7 & 27.6 & 2.26 & 1.97 & 2.67 & 2.24 & & & 2066.9 & & 1.68 & 39.67 & 21.7 & 36.95 \\
\hline 330.96 & 13.3 & 29 & 2.32 & 2.01 & 2.7 & 2.25 & & & 2102.2 & & & & & \\
\hline 331.87 & 14.3 & 30.6 & 2.3 & 1.97 & 2.68 & 2.2 & & & 2123.2 & & 1.92 & 31.65 & 33.21 & 33.22 \\
\hline 337.72 & 11.6 & 25.9 & 2.36 & 2.09 & 2.69 & 2.27 & & & 2229.3 & & & & & \\
\hline 338.96 & 12.18 & 27.14 & 2.37 & 2.08 & 2.73 & 2.25 & & & 2161.5 & & 1.6 & 44.92 & 24.07 & 29.41 \\
\hline 339.46 & 13.04 & 28.88 & 2.28 & 1.99 & 2.75 & 2.14 & & & 2106.5 & & & & & \\
\hline 347.28 & 12.24 & 26.76 & 2.31 & 2.03 & 2.66 & 2.3 & & & 2212.8 & & 1.11 & 45.49 & 21.89 & 31.51 \\
\hline 348.74 & 6.86 & 16.26 & 2.51 & 2.34 & 2.68 & & & & & & & & & \\
\hline 357.24 & 12.38 & 27.28 & 2.36 & 2.06 & 2.7 & 2.18 & & & 2215.4 & & 1.17 & 43.84 & 25.29 & 29.7 \\
\hline 358.33 & 12.35 & 27.07 & 2.3 & 2.02 & 2.68 & 2.28 & & & 2140.8 & & & & & \\
\hline 359.47 & 12.07 & 26.71 & 2.31 & 2.03 & 2.7 & 2.22 & & & 2219.9 & & 1.42 & 43.67 & 27.45 & 27.46 \\
\hline 376.58 & 12.85 & 28.3 & 2.34 & 2.04 & 2.72 & 2.19 & & & 2112.4 & & & & & \\
\hline 377.51 & 13.41 & 28.62 & 2.31 & 2 & 2.63 & 2.21 & & & 2147.8 & & 2.89 & 41.71 & 26.59 & 28.81 \\
\hline 378.15 & 13.82 & 29.22 & 2.22 & 1.92 & 2.61 & 2.24 & & & 2048.2 & & & & & \\
\hline 386.12 & 13.04 & 28.33 & 2.31 & 2.01 & 2.68 & 2.25 & & & 2125 & & 0.75 & 36.87 & 24.95 & 37.43 \\
\hline 395.75 & 12.15 & 26.98 & 2.32 & 2.04 & 2.72 & 2.27 & & & 2200 & & & & & \\
\hline 396.78 & 12.5 & 27.1 & 2.26 & 1.98 & 2.65 & 2.28 & & & 2188 & & 3.72 & 40.33 & 22.93 & 33.01 \\
\hline 397.43 & 12.3 & 27 & 2.28 & 2 & 2.67 & 2.3 & & & 2109.5 & & & & & \\
\hline 415.19 & 12.7 & 27.5 & 2.36 & 2.06 & 2.65 & & 476 & P & & & 0.72 & 39.85 & 23.77 & 35.66 \\
\hline 416.24 & 13.2 & 28.4 & 2.35 & 2.04 & 2.65 & 2.27 & & & 2102.2 & & & & & \\
\hline 416.93 & 12.64 & 27.28 & 2.25 & 1.97 & 2.63 & 2.2 & 727 & P & 2020.2 & & 1.14 & 38.2 & 22.95 & 37.44 \\
\hline 424.76 & 12.72 & 27.69 & 2.35 & 2.05 & 2.67 & 2.24 & & & 2008.8 & & & & & \\
\hline 426.14 & 13.86 & 28.65 & 2.24 & 1.93 & 2.53 & 2.24 & & & 2091.8 & & 2.17 & 37.3 & 26.63 & 33.9 \\
\hline 434.56 & 15.34 & 32.3 & 2.22 & 1.88 & 2.67 & 2.3 & & & 2282.1 & & & & & \\
\hline 435.4 & 12.51 & 28.09 & 2.41 & 2.11 & 2.78 & 2.17 & & & 2081.6 & & 1.11 & 36.75 & 33.56 & 28.58 \\
\hline 435.92 & 14.17 & 30.26 & 2.29 & 1.96 & 2.67 & 2.56 & & & 1990 & & & & & \\
\hline 440.14 & 13.47 & 29.11 & 2.33 & 2.01 & 2.68 & 2.26 & 696 & P & 2076.2 & & 1.68 & 45.27 & 21.22 & 31.83 \\
\hline 440.59 & 9.63 & 23.19 & 2.37 & 2.14 & 2.88 & 2.25 & & & 2090.4 & & & & & \\
\hline 444.15 & 13.55 & 29.45 & 2.29 & 1.98 & 2.71 & 2.39 & & & 2133.3 & & & & & \\
\hline 444.94 & 16.75 & 34.63 & 2.19 & 1.83 & 2.67 & & & & 1902.7 & & & & & \\
\hline 449.19 & 14.77 & 30.69 & 2.21 & 1.89 & 2.6 & 1.99 & & & 2161.7 & & & & & \\
\hline 449.88 & 13.57 & 29.43 & 2.39 & 2.07 & 2.7 & 2.23 & & & 1981.9 & & 2.13 & 24.46 & 23.49 & 49.92 \\
\hline 450.62 & & & & & & 2.5 & & & 2727.9 & & 15.11 & 29.19 & 38.43 & 17.27 \\
\hline 450.65 & & & & & & & & & 3476.7 & & & & & \\
\hline 453.63 & 2.28 & & & & & & & & 2036.1 & & & & & \\
\hline 458.75 & 15.67 & 30.89 & 2.25 & 1.9 & 2.44 & 2.21 & & & 2204.3 & & & & & \\
\hline 463.5 & 14.02 & 30.31 & 2.34 & 2.01 & 2.71 & 2.28 & 940 & P & 2192.4 & & & & & \\
\hline
\end{tabular}


Appendix (continued).

\begin{tabular}{|c|c|c|c|c|c|c|c|c|c|c|c|c|c|c|}
\hline \multirow{2}{*}{$\begin{array}{l}\text { Depth } \\
\text { (mbsf) }\end{array}$} & \multirow{2}{*}{$\begin{array}{l}\text { Water } \\
\text { content } \\
(\%)\end{array}$} & \multirow{2}{*}{$\begin{array}{c}\text { Porosity } \\
(\%)\end{array}$} & \multirow{2}{*}{$\begin{array}{l}\text { Wet-bulk } \\
\text { density } \\
\left(\mathrm{g} / \mathrm{cm}^{3}\right)\end{array}$} & \multirow{2}{*}{$\begin{array}{c}\text { Dry-bulk } \\
\text { density } \\
\left(\mathrm{g} / \mathrm{cm}^{3}\right)\end{array}$} & \multirow{2}{*}{$\begin{array}{l}\text { Grain } \\
\text { density } \\
\left(\mathrm{g} / \mathrm{cm}^{3}\right)\end{array}$} & GRAPE $^{a}$ & $\begin{array}{r}\mathrm{U} \\
\text { shea }\end{array}$ & $\begin{array}{l}\text { drained } \\
r \text { strength }\end{array}$ & & & & & & \\
\hline & & & & & & & $(\mathrm{kPa})$ & Instrument $^{\mathrm{b}}$ & $(\mathrm{m} / \mathrm{s})$ & $(\mathrm{m} / \mathrm{s})$ & $\begin{array}{l}\text { Gravel } \\
(\%)\end{array}$ & $\begin{array}{l}\text { Sand } \\
(\%)\end{array}$ & $\begin{array}{l}\text { Silt } \\
(\%)\end{array}$ & $(\%)$ \\
\hline Site 739 & & & & & & & & & & & & & & \\
\hline 464.29 & 13.4 & 28.4 & 2.3 & 1.99 & 2.6 & 2.3 & & & 2069.9 & & 2.97 & 39.69 & 20.65 & 36.7 \\
\hline 465.15 & 22.9 & 43.3 & 2.03 & 1.57 & 2.6 & 2.07 & & & 2007.1 & & & & & \\
\hline 466 & 17.87 & 36.15 & 2.19 & 1.8 & 2.64 & & & & 1977.3 & & 0.87 & 28.39 & 33.24 & 37.49 \\
\hline 468.75 & 17.18 & 33.97 & 2.21 & 1.83 & 2.52 & 2.23 & 925 & $P$ & 2053.6 & & & & & \\
\hline 473.25 & & & & & & & 830 & P & & & & & & \\
\hline 473.37 & 16.09 & 33.39 & 2.23 & 1.88 & 2.66 & 2.22 & 925 & P & 2004.3 & & 0.62 & 32.02 & 24.92 & 42.44 \\
\hline 474.2 & 8.94 & 19.28 & 2.46 & 2.24 & 2.47 & & & & 3401.6 & & & & & \\
\hline $\begin{array}{r}482.64 \\
16.86\end{array}$ & 6.49 & 15.06 & 2.55 & 2.38 & 2.6 & 2.33 & & & 2163.8 & & 4 & 0.22 & 23.13 & 59.79 \\
\hline Site $\mathbf{7 4 0}$ & & & & & & & & & & & & & & \\
\hline 0.6 & 74.9 & 87.43 & 1.22 & 0.31 & 2.31 & & 0.8 & F & & 1500 & & & & \\
\hline 0.6 & & & & & & & 0.9 & w & & & & & & \\
\hline 6.22 & 45.23 & 69.53 & 1.64 & 0.9 & 2.79 & & 3.2 & W & & 1490.7 & & & & \\
\hline 6.22 & & & & & & & 4.2 & $\mathrm{~F}$ & & & & & & \\
\hline 14.9 & 72.8 & 87.97 & 1.32 & 0.36 & 2.72 & & 0.2 & w & & & & & & \\
\hline 15.7 & 69.77 & 87.55 & 1.27 & 0.38 & 3.05 & & & & & & & & & \\
\hline 17.76 & 18.1 & 37.8 & 2.22 & 1.82 & 2.79 & & 24 & $\mathbf{F}$ & & 1701.5 & & & & \\
\hline 17.86 & & & & & & & 14.3 & W & & & & & & \\
\hline $\begin{array}{l}18.24 \\
18.38\end{array}$ & 17.58 & 35.9 & 2.17 & 1.79 & 2.67 & & $\begin{array}{l}53 \\
74\end{array}$ & $\begin{array}{l}F \\
F\end{array}$ & & 1704.7 & 2.12 & 40.5 & 21.80 & 35.57 \\
\hline 57 & & & & & & & & & & 2250 & & & & \\
\hline 57 & 18.06 & 37.41 & 2.22 & 1.82 & 2.75 & & 275 & F & & & & & & \\
\hline 58.8 & 22.1 & 44.68 & 2.36 & 1.84 & 2.89 & & 145 & F & & 1923.1 & & & & \\
\hline 60.45 & 14.83 & 32.5 & 2.45 & 2.09 & 2.81 & 2.33 & 370 & F & 2102.9 & 2274.1 & & & & \\
\hline 61.35 & 13.39 & 29.52 & 2.42 & 2.09 & 2.75 & 2.32 & & & 2275.5 & 1703.3 & & & & \\
\hline 61.3 & 16.02 & 33.81 & 2.26 & 1.9 & 2.72 & & & & & & & & & \\
\hline 66.66 & 18.14 & 38.76 & 2.25 & 1.84 & 2.9 & 2.17 & & & 2097.7 & & & & & \\
\hline 68.6 & 15.48 & 33.5 & 2.31 & 1.95 & 2.79 & 2.28 & & & 2027.2 & & & & & \\
\hline 71.63 & 16.34 & 35.12 & 2.29 & 1.92 & 2.81 & 2.19 & & & 1889.8 & & & & & \\
\hline 73.05 & 17.94 & 38.07 & 2.28 & 1.87 & 2.86 & & & & & 2197 & & & & \\
\hline 76 & 15.13 & 31.98 & 2.29 & 1.95 & 2.68 & 2.27 & & & 2348.3 & & & & & \\
\hline 76.68 & 18.23 & 37.63 & 2.26 & 1.85 & 2.75 & 2.35 & 650 & P & 2416.7 & & & & & \\
\hline 80.86 & 17.6 & 36.38 & 2.15 & 1.77 & 2.72 & 2.33 & & & 2227.3 & & & & & \\
\hline 81.6 & 17.13 & 35.36 & 2.22 & 1.84 & 2.69 & & 7.7 & P & & 1954.5 & & & & \\
\hline 85.97 & 15.43 & 33.6 & 1.77 & 1.49 & 2.82 & 2.39 & & & 2086.6 & & & & & \\
\hline 86.77 & 2.33 & & & & & & & & 2369 & & & & & \\
\hline 87.91 & 13.91 & 31.59 & 2.46 & 2.12 & 2.9 & 2.42 & & & 2147 & & & & & \\
\hline 88.9 & 12.18 & 27.13 & 2.4 & 2.11 & 2.73 & 2.34 & & & 2270 & & & & & \\
\hline 90.68 & 11.97 & 27.23 & 2.47 & 2.18 & 2.8 & 2.37 & & & 2418 & 2515 & & & & \\
\hline 91.45 & 11.55 & 26.09 & 2.46 & 2.17 & 2.75 & 2.41 & & & 2288 & 2651 & & & & \\
\hline 100.53 & 17.31 & 35.24 & 2.22 & 1.84 & 2.64 & 2.24 & & & 2108.4 & 2098 & & & & \\
\hline 101.49 & 14.44 & 31.29 & 2.32 & 1.99 & 2.74 & 2.35 & & & 2088.2 & 2227.3 & & & & \\
\hline 119.36 & 12.41 & 28.2 & 2.48 & 2.17 & 2.82 & 2.37 & & & 2541.4 & 2680.4 & & & & \\
\hline 120.27 & 11.27 & 26.55 & 2.56 & 2.27 & 2.89 & & & & 2337.8 & & & & & \\
\hline 128.67 & 10.89 & 25.14 & 2.59 & 2.31 & 2.79 & 2.29 & & & 2407.4 & & & & & \\
\hline 129.48 & 11.39 & 25.27 & 2.54 & 2.25 & 2.67 & 2.37 & & & 2659.3 & & & & & \\
\hline 126.05 & 9.87 & 22.91 & 2.7 & 2.43 & 2.76 & 2.48 & & & 2489.6 & & & & & \\
\hline 129.28 & 11.59 & 25.76 & 2.45 & 2.17 & 2.69 & 2.39 & & & 2313.3 & & & & & \\
\hline 130.9 & 14.36 & 31.42 & 2.34 & 2 & 2.77 & 2.28 & & & 2277.3 & & & & & \\
\hline 132.32 & 12.61 & 27.52 & 2.34 & 2.04 & 2.67 & 2.29 & & & 2291.7 & & & & & \\
\hline 138.79 & 14.3 & 31.09 & 2.32 & 1.99 & 2.75 & 2.23 & & & 2701.1 & & & & & \\
\hline 139.22 & 14.83 & 39.3 & 2.35 & 2 & 2.78 & 2.24 & & & 2362.2 & & & & & \\
\hline 148.81 & 8.5 & 19.99 & 2.65 & 2.42 & 2.73 & 2.39 & & & 2259.3 & & & & & \\
\hline 149.61 & & & & & & 2.31 & & & 2569.4 & & & & & \\
\hline 157.83 & 10.85 & 24.42 & 2.39 & 2.13 & 2.7 & 2.44 & & & 2712.7 & & & & & \\
\hline 159.47 & 12.06 & 27.28 & 2.43 & 2.13 & 2.78 & 2.41 & & & 2311.8 & & & & & \\
\hline 167.76 & 8.86 & 20.82 & 2.51 & 2.29 & 2.75 & 2.47 & & & 2628.9 & 2527.3 & & & & \\
\hline 168.73 & 10.35 & 24.27 & 2.53 & 2.27 & 2.82 & 2.42 & & & 2586.4 & 2721.6 & & & & \\
\hline 169.85 & 11.16 & 24.96 & 2.45 & 2.18 & 2.69 & 2.34 & & & 2532.5 & 2533.3 & & & & \\
\hline 170.88 & 9.7 & 21.56 & 2.41 & 2.18 & 2.6 & 2.33 & & & 2567.6 & 2650 & & & & \\
\hline 171.67 & 11.26 & 25.87 & 2.5 & 2.22 & 2.8 & 2.39 & & & 2385.7 & 2467.9 & & & & \\
\hline 172.64 & 11.15 & 24.4 & 2.44 & 2.17 & 2.61 & 2.35 & & & 2464.3 & 2480.8 & & & & \\
\hline 177.23 & 11.54 & 25.42 & 2.45 & 2.17 & 2.65 & 2.37 & & & 2624.3 & 2542.1 & & & & \\
\hline 178.39 & 10.21 & 22.52 & 2.45 & 2.2 & 2.6 & 2.35 & & & 2417.7 & 2176.5 & & & & \\
\hline 178.91 & 13.97 & 29.96 & 2.3 & 1.98 & 2.68 & & & & & & & & & \\
\hline 180.22 & 10.57 & 22.99 & 2.35 & 2.1 & 2.56 & & & & 2558.8 & 2839.5 & & & & \\
\hline 181.51 & 11.04 & 25.02 & 2.5 & 2.22 & 2.73 & 2.41 & & & 2720.5 & 2739.6 & & & & \\
\hline 181.9 & 10.9 & 23.61 & 2.41 & 2.14 & 2.57 & & & & 2641.2 & 2650.6 & & & & \\
\hline 183.64 & 10.91 & 23.84 & 2.43 & 2.17 & 2.6 & 2.38 & & & 2516.1 & & & & & \\
\hline 186.95 & 9.49 & 22.07 & 2.52 & 2.28 & 2.74 & 2.35 & & & 2691 & 2555.6 & & & & \\
\hline
\end{tabular}


Appendix (continued).

\begin{tabular}{|c|c|c|c|c|c|c|c|c|c|c|c|c|c|c|}
\hline \multirow{2}{*}{$\begin{array}{l}\text { Depth } \\
\text { (mbsf) }\end{array}$} & \multirow{2}{*}{$\begin{array}{c}\text { Water } \\
\text { content } \\
(\%)\end{array}$} & \multirow{2}{*}{$\begin{array}{c}\text { Porosity } \\
(\%)\end{array}$} & \multirow{2}{*}{$\begin{array}{l}\text { Wet-bulk } \\
\text { density } \\
\left(\mathrm{g} / \mathrm{cm}^{3}\right)\end{array}$} & \multirow{2}{*}{$\begin{array}{c}\text { Dry-bulk } \\
\text { density } \\
\left(\mathrm{g} / \mathrm{cm}^{3}\right)\end{array}$} & \multirow{2}{*}{$\begin{array}{l}\text { Grain } \\
\text { density } \\
\left(\mathrm{g} / \mathrm{cm}^{3}\right)\end{array}$} & GRAPE $^{\mathrm{a}}$ & & $\begin{array}{l}\text { drained } \\
\text { strength }\end{array}$ & & & & & & \\
\hline & & & & & & $\left(\mathrm{g} / \mathrm{cm}^{3}\right)$ & $(\mathrm{kPa})$ & Instrument ${ }^{b}$ & $(\mathrm{~m} / \mathrm{s})$ & $\begin{array}{l}\mathrm{VA}^{\mathrm{u}} \\
(\mathrm{m} / \mathrm{s})\end{array}$ & $\begin{array}{l}\text { Gravel } \\
(\%)\end{array}$ & $\begin{array}{l}\text { Sand } \\
(\%)\end{array}$ & $\begin{array}{l}\text { Silt } \\
(\%)\end{array}$ & $\begin{array}{l}\text { Clay } \\
(\%)\end{array}$ \\
\hline Site 740 & & & & & & & & & & & & & & \\
\hline 188.07 & 8.9 & 21.39 & 2.63 & 2.4 & 2.83 & 2.44 & & & 2445.9 & 2766.7 & & & & \\
\hline 188.77 & 9.1 & 20.77 & 2.49 & 2.26 & 2.66 & 2.45 & & & 2732 & 3039.2 & & & & \\
\hline 190.14 & 8.7 & 20.05 & 2.53 & 2.31 & 2.67 & 2.52 & & & 2560 & & & & & \\
\hline 197 & 12.23 & 26.06 & 2.37 & 2.08 & 2.57 & 2.25 & & & 2321.4 & 2261.3 & & & & \\
\hline 198.18 & 11.78 & 26.01 & 2.39 & 2.11 & 2.68 & 2.1 & & & 2291.3 & 2297.3 & & & & \\
\hline 199.2 & 11.76 & 27.18 & 2.51 & 2.21 & 2.85 & 2.36 & & & 2420.7 & 2415.1 & & & & \\
\hline 206.4 & 10.9 & 23.93 & 2.46 & 2.19 & 2.61 & 2.28 & & & 2385.7 & 2358.5 & & & & \\
\hline 207.23 & 10.01 & 22.5 & 2.44 & 2.2 & 2.65 & 2.32 & & & 2430.1 & 2533.3 & & & & \\
\hline 215.81 & 14.25 & 30.17 & 2.32 & 1.99 & 2.64 & 2.74 & & & 2064.4 & 2258.1 & & & & \\
\hline 217.74 & 9.76 & 22.31 & 2.66 & 2.4 & 2.7 & 2.31 & & & 2625.5 & 2722.8 & & & & \\
\hline 219.25 & 11.04 & 25.32 & 2.58 & 2.3 & 2.78 & 3.35 & & & 2302.3 & 2517.2 & & & & \\
\hline 223.13 & 12.87 & 31.33 & 2.34 & 2.04 & 3.14 & 2.32 & & & 2341.7 & 2383.3 & & & & \\
\hline 221.28 & 10.9 & 26.5 & 2.76 & 2.46 & 3 & 2.46 & & & 2555.6 & 2613.4 & & & & \\
\hline Site 741 & & & & & & & & & & & & & & \\
\hline 0.54 & 54.29 & 74.21 & 1.49 & 0.68 & 2.44 & & & & & & & & & \\
\hline 1.09 & 24.67 & 46.3 & 2.04 & 1.54 & 2.67 & & & & & 1600 & & & & \\
\hline 3.67 & 23.84 & 44.92 & 2.04 & 1.55 & 2.64 & & & & & 1580.7 & & & & \\
\hline 24.1 & 13.72 & 28.33 & 2.28 & 1.96 & 2.53 & 2.23 & & & & & & & & \\
\hline 24.82 & 11.67 & 26.25 & 2.45 & 2.17 & 2.74 & 2.27 & & & 2117.9 & & & & & \\
\hline 25.66 & 10.09 & 22.22 & 2.36 & 2.12 & 2.59 & 2.32 & & & 2457 & & & & & \\
\hline 26.38 & 15.69 & 28.74 & 2.26 & 1.9 & 2.2 & 2.08 & & & 1982.7 & & & & & \\
\hline 27.36 & 11.68 & 24.68 & 2.29 & 2.02 & 2.52 & 2.27 & & & 2292.4 & & & & & \\
\hline 33.84 & 15.71 & 30.92 & 2.13 & 1.8 & 2.44 & 2.09 & & & 2077.4 & & & & & \\
\hline 34.58 & 15.81 & 28.21 & 2.14 & 1.8 & 2.12 & 2.12 & & & 2249.2 & 2222.2 & & & & \\
\hline 35.38 & 13.92 & 29.57 & 2.25 & 1.94 & 2.64 & & & & 2142.9 & & & & & \\
\hline 35.9 & 12.74 & 26.66 & 2.3 & 2 & 2.53 & & & & 2058.8 & & 0.10 & 14.41 & 43.61 & 41.91 \\
\hline 43.28 & 13.52 & 27.47 & 2.26 & 1.96 & 2.46 & 2.16 & & & 1954.5 & & & & & \\
\hline 44.5 & 12.67 & 26.53 & 2.32 & 2.03 & 2.53 & 2.19 & & & 2083.9 & & & & & \\
\hline 45.58 & 10.32 & 24.61 & 2.45 & 2.19 & 2.88 & & & & 3239.7 & & & & & \\
\hline 46.58 & 12.71 & 25.87 & 2.19 & 1.91 & 2.43 & 2.14 & & & 2268.7 & & & & & \\
\hline 47.54 & 16.69 & 32.15 & 2.1 & 1.75 & 2.4 & 2.1 & & & 2038.3 & & & & & \\
\hline 48 & 13.21 & 27.98 & 2.3 & 2 & 2.59 & 2.27 & & & 2319.4 & & & & & \\
\hline 48.5 & 7.98 & 18.34 & 2.43 & 2.24 & 2.63 & 2.27 & & & 2603.9 & & & & & \\
\hline 53.59 & & & & & & 2.28 & & & 4743.1 & & & & & \\
\hline 54.56 & & & & & & & & & 3918.4 & & & & & \\
\hline 54.8 & 14.2 & 28.79 & 2.25 & 1.93 & 2.48 & 2.04 & & & 2091.7 & & & & & \\
\hline 62.72 & 16.92 & 31.68 & 2.16 & 1.79 & 2.31 & 2.24 & & & 2094.1 & & & & & \\
\hline 82.64 & 11.73 & 25.69 & 2.33 & 2.06 & 2.64 & 2.26 & & & 2291.5 & & & & & \\
\hline 84.02 & 11.74 & 24.8 & 2.25 & 1.99 & 2.52 & 2.21 & & & 2223.2 & & 0.00 & 8.45 & 32.94 & 58.61 \\
\hline 101.73 & 12.76 & 26.28 & 2.21 & 1.92 & 2.48 & 2.25 & & & 2180.5 & & & & & \\
\hline 103.07 & 13.4 & 28.48 & 2.24 & 1.94 & 2.61 & 2.16 & & & 2142 & & & & & \\
\hline 111.1 & 10.83 & 23.78 & 2.29 & 2.04 & 2.61 & 2.23 & & & 2506.6 & 2450.5 & & & & \\
\hline 112.59 & 13.87 & 28.62 & 2.25 & 1.94 & 2.53 & 2.17 & & & 2267.5 & 2267.2 & & & & \\
\hline 113.47 & 11.89 & 26.48 & 2.35 & 2.07 & 2.71 & 2.29 & & & 2310.1 & 2357.8 & & & & \\
\hline 114.17 & 13.59 & 27.8 & 2.24 & 1.93 & 2.49 & 2.09 & & & 2129.2 & 2162.4 & & & & \\
\hline 115.53 & 11.42 & 25.02 & 2.32 & 2.06 & 2.63 & 2.27 & & & 2238.3 & 2333.3 & & & & \\
\hline 120.84 & 12.11 & 25.89 & 1.88 & 1.65 & 2.57 & 2.16 & & & 2171.3 & 2200 & & & & \\
\hline 121.57 & 11.57 & 24.68 & 2.67 & 2.36 & 2.54 & 2.29 & & & 2220.4 & 2342.9 & & & & \\
\hline 123.45 & 13.29 & 27.2 & 2.44 & 2.12 & 2.48 & 2.29 & & & 2397.8 & 2551.4 & & & & \\
\hline 123.62 & 11.97 & 23.9 & 1.67 & 1.47 & 2.34 & 2.22 & & & 2289.1 & 2405.7 & & & & \\
\hline Site 742 & & & & & & & & & & & & & & \\
\hline 0.59 & 17.48 & 35.09 & 2.11 & 1.74 & 2.59 & & 15 & W & & 1774.2 & 3.17 & 47.86 & 17.38 & 31.59 \\
\hline 0.62 & & & & & & & 44 & F & & & & & & \\
\hline 1.2 & 20.1 & 38.66 & 2 & 1.6 & 2.54 & & 11 & F & & 1748.2 & & & & \\
\hline 1.23 & & & & & & & 13 & W & & & & & & \\
\hline 2.3 & & & & & & & 17 & W & & & & & & \\
\hline 2.36 & 16.57 & 33.84 & 2.16 & 1.8 & 2.61 & & 30 & $\mathrm{~F}$ & & 1811.4 & 4.03 & 48.73 & 18.19 & 29.05 \\
\hline 3.26 & 17.28 & 35.71 & 2.16 & 1.79 & 2.7 & & 10 & w & & & & & & \\
\hline 3.27 & & & & & & & 34 & F & & 1768.6 & & & & \\
\hline 4.2 & 17.55 & 36.54 & 2.17 & 1.79 & 2.75 & & 27 & w & & & 4.46 & 46.48 & 14.47 & 34.59 \\
\hline 4.21 & & & & & & & 31 & F & & 1768.6 & & & & \\
\hline 4.22 & & & & & & & 30 & w & & & & & & \\
\hline 5.3 & 15 & 31.5 & 2.19 & 1.86 & 2.64 & & 40 & W & 1913.4 & & & & & \\
\hline 5.3 & & & & & & & 64 & F & & & & & & \\
\hline 5.39 & 14.2 & 20.4 & 2.22 & 1.91 & 2.67 & & & & & & & & & \\
\hline 5.48 & 10.4 & 21.3 & 2.45 & 2.19 & 2.35 & & 123 & F & 1979.2 & & & & & \\
\hline 14.66 & 12.2 & 28.9 & 2.3 & 2.02 & 2.97 & 2.35 & 650 & P & 2099.1 & & & & & \\
\hline 15.2 & 11.7 & 25.8 & 2.3 & 2.03 & 2.68 & 2.37 & 770 & P & 2165 & & 3.56 & 50.81 & 4.11 & 41.52 \\
\hline
\end{tabular}


Appendix (continued).

\begin{tabular}{|c|c|c|c|c|c|c|c|c|c|c|c|c|c|c|}
\hline \multirow{2}{*}{$\begin{array}{l}\text { Depth } \\
\text { (mbsf) }\end{array}$} & \multirow{2}{*}{$\begin{array}{c}\text { Water } \\
\text { content } \\
(\%)\end{array}$} & \multirow{2}{*}{$\begin{array}{l}\text { Porosity } \\
(\%)\end{array}$} & \multirow{2}{*}{$\begin{array}{l}\text { Wet-bulk } \\
\text { density } \\
\left(\mathrm{g} / \mathrm{cm}^{3}\right)\end{array}$} & $\begin{array}{c}\text { Dry-bulk } \\
\text { density }\end{array}$ & $\begin{array}{l}\text { Grain } \\
\text { density }\end{array}$ & $\begin{array}{l}\text { GRAPE }^{a} \\
\text { density }\end{array}$ & & $\begin{array}{l}\text { drained } \\
\text { strength }\end{array}$ & $V_{p} A^{c}$ & $\mathrm{VpA}^{\mathrm{d}}$ & Gravel & Sand & Silt & Clay \\
\hline & & & & & $\left(\mathrm{g} / \mathrm{cm}^{3}\right)$ & $\left(\mathrm{g} / \mathrm{cm}^{3}\right)$ & $(\mathrm{kPa})$ & Instrument $^{\mathrm{b}}$ & $(\mathrm{m} / \mathrm{s})$ & $(\mathrm{m} / \mathrm{s})$ & $(\%)$ & $(\%)$ & $(\%)$ & $(\%)$ \\
\hline Site 742 & & & & & & & & & & & & & & \\
\hline 23.77 & 13.86 & 29.73 & 2.32 & 2 & 2.67 & 2.27 & 447 & $\mathrm{P}$ & 2119.6 & & & & & \\
\hline 23.93 & & & & & & & 447 & $\mathrm{P}$ & & & & & & \\
\hline 24.45 & & & & & & & 817 & $\mathrm{P}$ & & & & & & \\
\hline 37.97 & 13.6 & 29.84 & 2.3 & 1.98 & 2.74 & & 497 & $\mathrm{P}$ & 2169.3 & & & & & \\
\hline 38.14 & & & & & & 2.52 & & & 5130 & & & & & \\
\hline 56.03 & 10.93 & 24.38 & 2.33 & 2.08 & 2.67 & 2.4 & 530 & $\mathbf{P}$ & 2523.3 & & 3.35 & 45.98 & 12.67 & 38 \\
\hline 56.73 & 11.53 & 24.85 & 2.28 & 2.01 & 2.58 & 2.29 & 540 & $\mathrm{P}$ & 2084.5 & & 2.14 & 44.51 & 10.67 & 42.68 \\
\hline 57.41 & 11 & 24.44 & 2.33 & 2.07 & 2.66 & 2.32 & 626 & $\mathrm{P}$ & 2159.2 & & & & & \\
\hline 58.95 & 10.75 & 23.66 & 2.34 & 2.08 & 2.62 & 2.33 & & & 2208.7 & & 2.8 & 43.35 & 9.69 & 44.16 \\
\hline 59.57 & & & & & & & 705 & $\mathrm{P}$ & & & & & & \\
\hline 59.74 & 14.1 & 30.31 & 2.27 & 1.95 & 2.69 & 2.24 & 500 & $\mathbf{P}$ & 1923.1 & & & & & \\
\hline 65.3 & 11.38 & 25.17 & 2.32 & 2.06 & 2.66 & 2.31 & 382 & $\mathrm{P}$ & 2147.2 & & 4.95 & 42.83 & 14.62 & 37.6 \\
\hline 65.46 & & & & & & & 740 & $P$ & & & & & & \\
\hline 75.04 & 11.05 & 24.17 & 2.31 & 2.06 & 2.61 & 2.33 & 460 & $\mathrm{P}$ & 2440.7 & & 1.27 & 47.82 & 50.91 & \\
\hline 75.95 & & & & & & & 643 & $\mathbf{P}$ & & & & & & \\
\hline 76.14 & 11.19 & 24.68 & 2.31 & 2.05 & 2.64 & 2.39 & 643 & P & 2029.4 & 2484 & & & & \\
\hline 76.65 & & & & & & 2.32 & 585 & $\mathrm{P}$ & 2125 & 2066 & & & & \\
\hline 77.09 & 13.16 & 28.94 & 2.32 & 2.01 & 2.73 & & & & & & 1.73 & 47.21 & 17.62 & 33.44 \\
\hline 78.08 & 12.13 & 26.27 & 2.33 & 2.05 & 2.62 & 2.34 & 447 & $P$ & 2179.6 & 2152.7 & & & & \\
\hline 84.82 & 10.7 & 23.94 & 2.35 & 2.1 & 2.67 & 2.33 & 730 & $\mathrm{P}$ & 2164 & 2345.8 & 2.76 & 45.17 & 11.2 & 40.87 \\
\hline 85.61 & 12.43 & 27.23 & 2.35 & 2.06 & 2.68 & 2.3 & 753 & $\mathrm{P}$ & 2130 & 2165.3 & & & & \\
\hline 86.55 & 12.37 & 26.79 & 2.28 & 2 & 2.63 & 2.32 & 383 & $\mathrm{P}$ & 2036 & 2007.5 & 0.51 & 44.89 & 21.84 & 32.76 \\
\hline 104.2 & 15.31 & 32.53 & 2.15 & 1.82 & 2.71 & 2.3 & & & 2012.2 & 1986.8 & & & & \\
\hline 113.56 & 13.28 & 27.94 & 2.26 & 1.96 & 2.57 & 2.31 & 500 & $P$ & 2107.8 & 2285.7 & 3.02 & 46.21 & 13.70 & 37.07 \\
\hline 114.43 & 16.98 & 32.84 & 2.21 & 1.83 & 2.43 & 2.28 & & & 1846.8 & 2047.6 & & & & \\
\hline 115.37 & 17.3 & 33.62 & 2.22 & 1.84 & 2.46 & 1.78 & & & 1916.3 & 2055.6 & 0.2 & 26.51 & 20.15 & 53.14 \\
\hline 116.94 & 17.06 & 35.6 & 2.11 & 2.58 & 2.73 & 1.86 & & & 1700.7 & & & & & \\
\hline 123.24 & 26.2 & 46.91 & 2 & 1.48 & 2.52 & 2.07 & 447 & $\mathrm{P}$ & 1716.7 & 1697.8 & 0 & 1.9 & 29.92 & 68.18 \\
\hline 124.04 & 19.48 & 38.62 & 2.12 & 1.71 & 2.64 & 2 & & & 1810.5 & 1773.7 & & & & \\
\hline 125.62 & 27.2 & 47.1 & 1.98 & 1.44 & 2.42 & 1.91 & 307 & $\mathrm{P}$ & 1726.9 & 1709.7 & 0 & 6.65 & 27.07 & 66.28 \\
\hline 126.22 & 19.03 & 38.84 & 2.15 & 1.74 & 2.74 & 2.21 & & & 1891.2 & 1957.6 & & & & \\
\hline 127.3 & & & & & & & 350 & $P$ & & & & & & \\
\hline 128.05 & 25.99 & 47.53 & 1.98 & 1.47 & 2.62 & 2.04 & 400 & $\mathrm{P}$ & 1756.9 & 1821.7 & 0 & 8.85 & 25.98 & 65.17 \\
\hline 133.3 & 17.25 & 35.4 & 2.19 & 1.81 & 2.67 & 2.11 & 420 & $\mathbf{P}$ & 1780.9 & 1750 & 2.76 & 34.02 & 22.75 & 40.45 \\
\hline 135.1 & 18.65 & 38.79 & 2.28 & 1.86 & 2.81 & 2.14 & & & 2059.9 & & & & & \\
\hline 135.71 & 13.14 & 27.71 & 2.39 & 2.07 & 2.57 & 2.3 & & & 2123.3 & 2289.9 & & & & \\
\hline 142.85 & 12.77 & 26.74 & 2.32 & 2.03 & 2.53 & 2.29 & 370 & $\mathrm{~F}$ & 2163.9 & 1948.9 & 2.55 & 47.70 & 13.94 & 35.81 \\
\hline 144.71 & 8.43 & 18.86 & 2.32 & 2.13 & 2.56 & 2.3 & & & 2133.6 & & & & & \\
\hline 145.58 & & & & & & 2.23 & & & 1886.6 & & 1.91 & 40.61 & 17.24 & 40.24 \\
\hline 147.23 & 10.57 & 22.14 & 2.26 & 2.02 & 2.44 & 2.23 & & & 2153.3 & & & & & \\
\hline 148.97 & 10.09 & 22.09 & 2.47 & 2.22 & 2.57 & 2.35 & & & 2050.4 & & 6.46 & 42.01 & 12.88 & 38.65 \\
\hline 149.81 & 14.03 & 29.26 & 2.28 & 1.96 & 2.57 & 2.33 & & & 2016.9 & & & & & \\
\hline 152.52 & 11.39 & 25.17 & 2.34 & 2.07 & 2.66 & 2.3 & & & 2251.3 & 2348.6 & 3.74 & 45.59 & 17.48 & 33.19 \\
\hline 153.76 & 14.73 & 29.75 & 2.18 & 1.86 & 2.49 & 2.29 & & & 2185.5 & & & & & \\
\hline 155.46 & 13.11 & 27.18 & 2.27 & 1.97 & 2.51 & 2.3 & & & 2107.3 & & & & & \\
\hline 156.98 & 12.2 & 26.79 & 2.32 & 2.04 & 2.67 & 2.26 & & & 2141.1 & & & & & \\
\hline 158.5 & 13.99 & 27.94 & 2.22 & 1.91 & 2.42 & 2.29 & & & 2276.9 & & 0.5 & 47.81 & 18.09 & 33.6 \\
\hline 159.82 & 13.27 & 25.99 & 2.21 & 1.92 & 2.33 & 2.31 & & & 2235.7 & & & & & \\
\hline 162.3 & 11.62 & 24.33 & 2.36 & 2.08 & 2.48 & 2.31 & & & 2266.1 & 2333.3 & 1.44 & 47.34 & 15.11 & 36.11 \\
\hline 163.61 & 13.17 & 28.45 & 2.32 & 2.02 & 2.66 & 2.3 & & & 2247.4 & & & & & \\
\hline 165.58 & 11.2 & 24.78 & 2.44 & 2.17 & 2.65 & 2.33 & & & 2177.8 & & 2.34 & 48.97 & 13.63 & 35.06 \\
\hline 166.83 & 10.26 & 22.77 & 2.33 & 2.09 & 2.62 & 2.26 & & & 2145.4 & & & & & \\
\hline 168.14 & 10.46 & 22.99 & 2.3 & 2.06 & 2.6 & 2.3 & & & 2114.5 & & 0.77 & 50.55 & 16.06 & 32.62 \\
\hline 169.89 & 10.84 & 24.11 & 2.31 & 2.06 & 2.66 & 2.32 & & & 2222.2 & 2157.4 & & & & \\
\hline 171.86 & 11.58 & 25.42 & 2.31 & 2.04 & 2.64 & 2.29 & 600 & $\mathbf{P}$ & 2190.5 & & 0.71 & 47.36 & 16.36 & 35.57 \\
\hline 173.43 & 13.42 & 28.57 & 2.23 & 1.93 & 2.62 & 2.34 & 583 & $\mathrm{P}$ & 1936.7 & & & & & \\
\hline 174.7 & 16.21 & 32.72 & 2.12 & 1.77 & 2.55 & 2.18 & 437 & $\mathrm{P}$ & 1892.9 & & 0.93 & 29.53 & 27.47 & 42.07 \\
\hline 181.11 & 14.18 & 29.21 & 2.2 & 1.89 & 2.54 & 2.28 & 800 & $\mathrm{P}$ & 2000 & 2048.4 & & & & \\
\hline 182.35 & & & & & & & 778 & $\mathrm{P}$ & & & & & & \\
\hline 183.13 & 14.64 & 31.05 & 2.21 & 1.89 & 2.67 & 2.28 & 740 & $\mathrm{P}$ & 2014 & 2028.4 & 3.05 & 30.32 & 23.65 & 42.98 \\
\hline 184.29 & 17.44 & 35.95 & 2.14 & 1.76 & 2.7 & 2.19 & & & 1957.8 & 2311.9 & & & & \\
\hline 191.42 & 14.42 & 30.14 & 2.2 & 1.88 & 2.6 & 2.25 & & & 1894.7 & & 0.99 & 37.16 & 31.23 & 30.62 \\
\hline 192.61 & & & & & & 2.18 & & & 1886.4 & & & & & \\
\hline 192.72 & 16.3 & 34.05 & 2.27 & 1.9 & 2.69 & & & & & & & & & \\
\hline 194.57 & 16.21 & 33.33 & 2.17 & 1.82 & 2.62 & 2.18 & & & 1931.4 & & 2.65 & 27.42 & 27.27 & 42.66 \\
\hline 196.24 & 12.25 & 26.86 & 2.38 & 2.09 & 2.67 & 2.29 & & & 2080.2 & & & & & \\
\hline 197.31 & & & & & & 2.27 & & & 2052.6 & & 1.99 & 30.95 & 36.21 & 30.85 \\
\hline 197.52 & 12.32 & 26.34 & 2.27 & 1.99 & 2.59 & & & & & & & & & \\
\hline 201 & 12.44 & 26.47 & 2.26 & 1.98 & 2.58 & 2.27 & & & 2038.8 & & 1.87 & 40.53 & 57.6 & \\
\hline 202.63 & 13.09 & 27.47 & 2.23 & 1.94 & 2.55 & 2.22 & & & 2079.5 & & & & & \\
\hline 204.03 & 12.57 & 26.99 & 2.26 & 1.98 & 2.61 & 2.29 & & & 2062.5 & & 1.42 & 43.06 & 23.32 & 32.2 \\
\hline 205.51 & 12.03 & 26.18 & 2.37 & 2.08 & 2.64 & 2.26 & & & 2071.8 & & & & & \\
\hline
\end{tabular}


Appendix (continued).

\begin{tabular}{|c|c|c|c|c|c|c|c|c|c|c|c|c|c|c|}
\hline \multirow{2}{*}{$\begin{array}{l}\text { Depth } \\
\text { (mbsf) }\end{array}$} & \multirow{2}{*}{$\begin{array}{c}\text { Water } \\
\text { content } \\
(\%)\end{array}$} & \multirow{2}{*}{$\begin{array}{l}\text { Porosity } \\
(\%)\end{array}$} & \multirow{2}{*}{$\begin{array}{l}\text { Wet-bulk } \\
\text { density } \\
\left(\mathrm{g} / \mathrm{cm}^{3}\right)\end{array}$} & \multirow{2}{*}{$\begin{array}{c}\text { Dry-bulk } \\
\text { density } \\
\left(\mathrm{g} / \mathrm{cm}^{3}\right)\end{array}$} & $\begin{array}{l}\text { Grain } \\
\text { density }\end{array}$ & $\begin{array}{c}\text { GRAPE }^{\mathrm{a}} \\
\text { density }\end{array}$ & & $\begin{array}{l}\text { idrained } \\
\text { strength }\end{array}$ & $\mathrm{VpA}^{\mathrm{c}}$ & $\mathrm{VpA}^{\mathrm{d}}$ & Gravel & Sand & Silt & Clay \\
\hline & & & & & & $\left(\mathrm{g} / \mathrm{cm}^{3}\right)$ & $(\mathrm{kPa})$ & Instrument ${ }^{\mathrm{b}}$ & $(\mathrm{m} / \mathrm{s})$ & $(\mathrm{m} / \mathrm{s})$ & $(\%)$ & $(\%)$ & $(\%)$ & $(\%)$ \\
\hline Site 742 & & & & & & & & & & & & & & \\
\hline 205.72 & 2.05 & 5.1 & 2.66 & 2.6 & 2.61 & 2.6 & & & 4188.9 & & & & & \\
\hline 207.03 & 11.66 & 25.67 & 2.36 & 2.08 & 2.66 & 2.32 & & & 2085 & & & & & \\
\hline 208.56 & 11.76 & 25.39 & 2.29 & 2.02 & 2.59 & 2.3 & & & 2106.3 & & 1.01 & 44.33 & 20.5 & 34.16 \\
\hline 210.71 & 11.4 & 24.39 & 2.26 & 2 & 2.55 & 2.31 & & & 2120.2 & & & & & \\
\hline 212.22 & 11.67 & 25.54 & 2.32 & 2.05 & 2.64 & 2.27 & 708 & $\mathbf{P}$ & & & 1.45 & 43.75 & 21.37 & 33.43 \\
\hline 213.84 & 11.38 & 25.11 & 2.28 & 2.02 & 2.65 & 2.31 & & & 2071.4 & & 1.71 & 43.59 & 54.7 & \\
\hline 215.09 & 11.14 & 24.33 & 2.35 & 2.09 & 2.6 & 2.3 & & & 2107.3 & & 1.75 & 44.42 & 29.34 & 24.49 \\
\hline 229.91 & 15 & 30.68 & 2.19 & 1.86 & 2.55 & 2.2 & & & 2009.3 & & 0.88 & 18.4 & 29.87 & 50.85 \\
\hline 231.46 & 12.53 & 25.97 & 2.22 & 1.94 & 2.49 & 2.23 & & & 2101.5 & & 0.81 & 32.11 & 32.87 & 34.21 \\
\hline 232.9 & 11.92 & 26.01 & 2.27 & 2 & 2.64 & 2.24 & & & 2195.1 & & & & & \\
\hline 234.4 & 12.39 & 26.9 & 2.32 & 2.03 & 2.64 & 2.29 & & & 2155.7 & & 1.9 & 37.16 & 24.38 & 36.56 \\
\hline 239.53 & 13.73 & 28.65 & 2.24 & 1.94 & 2.56 & & & & & & & & & \\
\hline 241.08 & 11.84 & 25.43 & 2.26 & 1.99 & 2.58 & 2.28 & & & 2109.7 & & 1.52 & 38.87 & 25.93 & 33.68 \\
\hline 242.57 & 12.13 & 25.99 & 2.25 & 1.97 & 2.58 & 2.27 & & & 2053.7 & & & & & \\
\hline 244.06 & 13.96 & 29.52 & 2.27 & 1.95 & 2.62 & 2.27 & & & 2029.7 & & & & & \\
\hline 246.95 & & & & & & 2.28 & & & 2078.3 & & & & & \\
\hline 247.18 & 11.91 & 25.68 & 2.26 & 1.99 & 2.6 & & & & & & 1.8 & 39.87 & 21.58 & 36.75 \\
\hline 248.51 & 13.19 & 28.84 & 2.29 & 1.99 & 2.71 & 2.2 & & & 1916.1 & & & & & \\
\hline 251.1 & 11.84 & 26.71 & 2.31 & 2.03 & 2.76 & 2.25 & & & 1974.7 & & 0.97 & 39.11 & 23.37 & 36.55 \\
\hline 252.6 & 13.39 & 28.38 & 2.16 & 1.87 & 2.6 & 2.03 & & & 2154.8 & & 4.88 & 31.72 & 25.68 & 37.72 \\
\hline 254.03 & 14.37 & 30.49 & 2.24 & 1.92 & 2.66 & 2.23 & & & 2068.8 & & & & & \\
\hline 257.15 & 12.01 & 26.06 & 2.37 & 2.08 & 2.62 & 2.23 & & & 2137.7 & & 0.86 & 41.35 & 23.4 & 34.39 \\
\hline 258.7 & 12.89 & 28.23 & 2.22 & 1.93 & 2.7 & & & & & & & & & \\
\hline 260 & 10.99 & 26.22 & 2.45 & 2.18 & 2.92 & 2.11 & & & 1795.3 & & 6.67 & 40.4 & 16.67 & 36.26 \\
\hline 261.9 & 12.16 & 27.28 & 2.3 & 2.02 & 2.75 & 2.3 & & & 2118.8 & & & & & \\
\hline 262.84 & 12.52 & 27.54 & 2.34 & 2.05 & 2.7 & 2.31 & & & 2117.3 & & 4.39 & 40.07 & 21.94 & 33.6 \\
\hline 265.08 & 11.94 & 26.6 & 2.5 & 2.2 & 2.72 & 2 & & & 1808.4 & & & & & \\
\hline 266.37 & 12.17 & 27.15 & 2.35 & 2.06 & 2.73 & 2.34 & & & 2055 & & 1.04 & 43.29 & 55.67 & \\
\hline 268.3 & 11.62 & 26.64 & 2.41 & 2.13 & 2.81 & 2.33 & & & 1673.5 & & & & & \\
\hline 269.7 & 15.16 & 31.2 & 2.21 & 1.87 & 2.58 & 2.26 & & & 1910.1 & & 2.75 & 36.28 & 26.52 & 34.45 \\
\hline 271.1 & 17.39 & 35.56 & 2.16 & 1.78 & 2.66 & 2.15 & & & 1757.4 & & 1.34 & 41.27 & 21.52 & 35.87 \\
\hline 272.6 & 11.7 & 27.21 & 2.41 & 2.13 & 2.87 & 2.28 & & & 2009.4 & & & & & \\
\hline 274.28 & 13.66 & 29.4 & 2.23 & 1.93 & 2.67 & 2.26 & & & 1977.9 & & 4.14 & 25.31 & 28.22 & 42.33 \\
\hline 275.4 & 13.84 & 29.37 & 2.24 & 1.93 & 2.63 & 2.22 & & & 2000 & & & & & \\
\hline 277.84 & 11.65 & 25.91 & 2.29 & 2.03 & 2.7 & & & & 2060.8 & & 4.55 & 39.28 & 21.34 & 34.83 \\
\hline 279.52 & 13.61 & 30.8 & 2.28 & 1.97 & 2.87 & 2.26 & & & 2101.6 & & & & & \\
\hline 281.4 & 10.63 & 24.1 & 2.34 & 2.1 & 2.71 & & & & 2045.5 & & & & & \\
\hline 282.63 & 10.64 & 24.09 & 2.43 & 2.18 & 2.71 & 2.33 & & & 2206.3 & & 1.02 & 40.76 & 22.71 & 35.51 \\
\hline 287.4 & 12.09 & 26.32 & 2.33 & 2.05 & 2.64 & 2.25 & & & 2167.7 & & & & & \\
\hline 289.57 & 11.84 & 27.16 & 2.39 & 2.11 & 2.82 & 2.38 & & & 2111.1 & & 1.31 & 44.87 & 21.26 & 32.56 \\
\hline 290.63 & 11.78 & 25.48 & 2.24 & 1.98 & 2.6 & 2.4 & & & 2046.9 & & & & & \\
\hline 296.99 & 14.07 & 30.35 & 2.28 & 1.96 & 2.7 & 2.27 & & & 2202.9 & & 2.15 & 42.89 & 21.16 & 33.8 \\
\hline 298.95 & 11.4 & 25.52 & 2.35 & 2.08 & 2.71 & 2.32 & & & 2178.7 & & & & & \\
\hline 299.94 & 15.22 & 33.71 & 2.29 & 1.94 & 2.88 & 2.32 & & & 2156.5 & & 1 & 47.22 & 17.35 & 34.43 \\
\hline 302.1 & 14.08 & 30.07 & 2.18 & 1.87 & 2.67 & 2.3 & & & 2087.3 & & & & & \\
\hline 303.56 & 11.91 & 26.1 & 2.31 & 2.03 & 2.65 & 2.23 & & & 2152.1 & & 2.76 & 37.78 & 25.27 & 34.19 \\
\hline 304.29 & 14.76 & 32.46 & 2.36 & 2.01 & 2.82 & 2.19 & & & & & & & & \\
\hline 307.13 & 15.44 & 32.66 & 2.19 & 1.85 & 2.7 & 2.16 & 800 & $\mathrm{P}$ & 1929.3 & & 0 & 10.11 & 50.79 & 39.1 \\
\hline 310.07 & 12.34 & 27.28 & 2.26 & 1.98 & 2.71 & 2.28 & & & 1964.3 & & & & & \\
\hline 312.38 & & & & & & 2.24 & & & 2087 & & & & & \\
\hline 312.54 & 11.11 & 24.68 & 2.24 & 1.99 & 2.66 & 2.15 & 588 & $\mathrm{P}$ & & & 1.23 & 49.39 & 31.11 & 18.27 \\
\hline 313.4 & & & & & & & 527 & $\mathrm{P}$ & & & & & & \\
\hline 314.06 & 10.25 & 23.49 & 2.38 & 2.14 & 2.73 & & 630 & $\mathbf{P}$ & 2053.7 & & & & & \\
\hline 314.7 & & & & & & & 863 & & & & & & & \\
\hline Site 743 & & & & & & & & & & & & & & \\
\hline 0.9 & 17.37 & 36 & 2.23 & 1.85 & 2.72 & & 30 & $\mathbf{F}$ & 1696.1 & & & & & \\
\hline 1.14 & 19.5 & 38.75 & 2.12 & 1.71 & 2.65 & & 24 & $\mathrm{~F}$ & 1713.6 & & 1.74 & 52.41 & 16.51 & 29.34 \\
\hline 1.77 & 15.01 & 33.49 & 2.38 & 2.02 & 2.9 & & 62 & F & & & & & & \\
\hline 3.03 & & & & & & & 170 & $\mathrm{~F}$ & & & & & & \\
\hline 3.04 & 12.34 & 27.58 & 2.41 & 2.12 & 2.75 & & 123 & F & 2251.8 & & 6.38 & 49.79 & 10.08 & 33.75 \\
\hline 3.06 & 11.84 & 26.43 & 2.35 & 2.07 & 2.72 & & & & & & & & & \\
\hline 3.46 & & & & & & & 38 & $\mathbf{F}$ & 1702 & & & & & \\
\hline 3.83 & 17.4 & 36.37 & 2.23 & 1.84 & 2.76 & & 30 & F & 1828.7 & & 7.16 & 52.18 & 16.26 & 24.4 \\
\hline 4.1 & 17.89 & 36.22 & 2.17 & 1.78 & 2.65 & & 34 & $\mathbf{F}$ & 1850.5 & & & & & \\
\hline 4.27 & 18.8 & 38.9 & 2.14 & 1.74 & 2.79 & & 39 & $\mathrm{~F}$ & 1809.4 & & 1.68 & 50.05 & 18.34 & 29.93 \\
\hline 5.03 & 17.73 & 36.58 & 2.17 & 1.78 & 2.72 & & 32 & F & 1837.9 & & & & & \\
\hline 5.48 & 15.36 & 32.86 & 2.27 & 1.92 & 2.74 & & 44 & F & 1851.7 & & 3.9 & 62.6 & 16.41 & 17.09 \\
\hline 6.45 & 17.11 & 35.76 & 2.18 & 1.81 & 2.74 & & & & & & & & & \\
\hline 7.1 & 15.59 & 33.18 & 2.27 & 1.91 & 2.73 & & 35 & $\mathrm{~F}$ & 1796.9 & & 4.29 & 45.09 & 17.72 & 32.9 \\
\hline 8.01 & 17.9 & 37.11 & 2.17 & 1.78 & 2.75 & & 51 & F & 1789.4 & & 5.11 & 40.6 & 19.54 & 34.75 \\
\hline
\end{tabular}


Appendix (continued).

\begin{tabular}{|c|c|c|c|c|c|c|c|c|c|c|c|c|c|c|}
\hline \multirow{2}{*}{$\begin{array}{l}\text { Depth } \\
\text { (mbsf) }\end{array}$} & \multirow{2}{*}{$\begin{array}{c}\text { Water } \\
\text { content } \\
(\%)\end{array}$} & \multirow{2}{*}{$\begin{array}{c}\text { Porosity } \\
(\%)\end{array}$} & \multirow{2}{*}{$\begin{array}{c}\text { Wet-bulk } \\
\text { density } \\
\left(\mathrm{g} / \mathrm{cm}^{3}\right)\end{array}$} & \multirow{2}{*}{$\begin{array}{c}\text { Dry-bulk } \\
\text { density } \\
\left(\mathrm{g} / \mathrm{cm}^{3}\right)\end{array}$} & \multirow{2}{*}{$\begin{array}{l}\text { Grain } \\
\text { density } \\
\left(\mathrm{g} / \mathrm{cm}^{3}\right)\end{array}$} & \multirow{2}{*}{$\begin{array}{c}\text { GRAPE }^{a} \\
\text { density } \\
\left(\mathrm{g} / \mathrm{cm}^{3}\right)\end{array}$} & \multicolumn{2}{|c|}{$\begin{array}{l}\text { Undrained } \\
\text { shear strength }\end{array}$} & \multirow{2}{*}{$\begin{array}{l}\mathrm{VpA}^{\mathrm{c}} \\
(\mathrm{m} / \mathrm{s})\end{array}$} & \multirow{2}{*}{$\begin{array}{l}\mathrm{VpA}^{\mathrm{d}} \\
(\mathrm{m} / \mathrm{s})\end{array}$} & \multirow{2}{*}{$\begin{array}{c}\text { Gravel } \\
(\%)\end{array}$} & \multirow{2}{*}{$\begin{array}{l}\text { Sand } \\
(\%)\end{array}$} & \multirow{2}{*}{$\begin{array}{l}\text { Silt } \\
(\%)\end{array}$} & \multirow{2}{*}{$\begin{array}{l}\text { Clay } \\
(\%)\end{array}$} \\
\hline & & & & & & & $(\mathrm{kPa})$ & Instrument ${ }^{b}$ & & & & & & \\
\hline \multicolumn{15}{|l|}{ Site 743} \\
\hline 8.79 & 16.44 & 35.03 & 2.26 & 1.88 & 2.78 & & 72 & $\mathrm{~F}$ & 1806.3 & & & & & \\
\hline 9.32 & 19.34 & 40.02 & 2.18 & 1.76 & 2.83 & & 67 & F & 1743.4 & & 1.82 & 42.45 & 15.33 & 40.4 \\
\hline 9.81 & 19.79 & 39.8 & 2.11 & 1.69 & 2.72 & & 11 & F & 1766.3 & & & & & \\
\hline 10.03 & 32.28 & 54.87 & 1.83 & 1.24 & 2.59 & & 36 & $\mathrm{~F}$ & 1699 & & 0.98 & 21.93 & 22.74 & 54.35 \\
\hline 10.52 & 34.05 & 58.58 & 1.84 & 1.21 & 2.78 & & 48 & $\mathrm{~F}$ & 1573.8 & & 0 & 2.92 & 36.89 & 60.19 \\
\hline 10.81 & 33.6 & 57.77 & 1.85 & 1.23 & 2.74 & & 54 & $\mathrm{~F}$ & 1525.3 & & 0 & 0.46 & 35.34 & 64.2 \\
\hline 11.31 & 31.8 & 54.89 & 1.86 & 1.27 & 2.64 & & 46 & $\mathrm{~F}$ & 1588 & & & & & \\
\hline 11.54 & 16.74 & 35.01 & 2.21 & 1.84 & 2.72 & & & & & & 4.47 & 49.6 & 16.08 & 29.85 \\
\hline 13.13 & 17.6 & 36.72 & 2.23 & 1.84 & 2.76 & & 48 & $\mathrm{~F}$ & 1722.9 & & & & & \\
\hline 15.83 & 24.03 & 46.52 & 2.02 & 1.53 & 2.79 & & 27 & $\mathrm{~F}$ & & & 4.21 & 33.83 & 27.26 & 34.7 \\
\hline 16.21 & 18.45 & 38.26 & 2.18 & 1.78 & 2.78 & & 44 & $\mathrm{~F}$ & 1841.8 & & 1,42 & 38.45 & 15.34 & 44.79 \\
\hline 41.11 & 13.79 & 30.17 & 2.28 & 1.97 & 2.74 & & 103 & $\mathrm{~F}$ & 2534.6 & & & & & \\
\hline 41.24 & & & & & & & & & 2457.1 & & & & & \\
\hline 41.65 & & & & & & & & & & & 4.40 & 48.39 & 10.62 & 36.59 \\
\hline 42.11 & 13.67 & 29.99 & 2.36 & 2.04 & 2.75 & & 195 & F & 2054.3 & & 2.16 & 49.7 & 18.53 & 29.61 \\
\hline 42.83 & 13.48 & 29.23 & 2.31 & 2 & 2.69 & & 205 & $\mathrm{~F}$ & 1908.5 & & & & & \\
\hline 50.6 & & & & & & & & & & & 4.44 & 46.4 & 21.14 & 28.02 \\
\hline 51.1 & 15.11 & 32.32 & 2.29 & 1.95 & 2.72 & & 135 & F & 1922.6 & & & & & \\
\hline 51.7 & & & & & & & 225 & $\mathrm{~F}$ & 2086.7 & & 4.31 & 46.9 & 18.05 & 30.74 \\
\hline 52.17 & 13.74 & 30.12 & 2.34 & 2.02 & 2.75 & & 370 & $\mathrm{~F}$ & 1875.8 & & 2.34 & 47.81 & 15.45 & 34.4 \\
\hline 69.5 & 12.78 & 27.93 & 2.36 & 2.06 & 2.69 & & 235 & $\mathrm{~F}$ & 1988 & & & & & \\
\hline 69.89 & 12.59 & 27.68 & 2.46 & 2.15 & 2.7 & & 370 & $\mathrm{~F}$ & 2133 & & 1.29 & 54.55 & 16.34 & 27.82 \\
\hline
\end{tabular}

${ }^{a}$ Wet-bulk density measured by the gamma ray attenuation porosity evaluator (GRAPE).

${ }^{\mathrm{b}} \mathrm{P}=$ pocket penetrometer; $\mathrm{F}=$ fall-conepenetrometer; $\mathrm{W}=$ Wykeham-Farrance motorized vane.

c $P$-wave velocity measured parallel to the core.

d $P$-wave velocity measured normal to the core. 